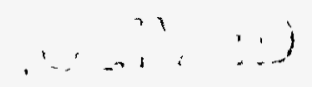

ก.ม

$03 T 1$

\title{
RADIOLOGICAL DOSE ASSESSMENT for BOUNDING ACCIDENT SCENARIOS at the CRITICAL EXPERIMENT FACILITY, TA-18, LOS ALAMOS NATIONAL LABORATORY
}

\section{DISCLAIMER}

This report was prepared as an account of work sponsored by an agency of the United States Government. Neither the United States Government nor any agency thereof, nor any of their employees, makes any warranty, express or implied, or assumes any legal liability or responsibility for the accuracy, completeness, or usefulness of any information, apparatus, product, or process disclosed, or represents that its use would not infringe privately owned rights. Reference herein to any specific commercial product, process, or service by trade name, trademark, manufacturer, or otherwise does not necessarily constitute or imply its endorsement, recommendation, or favoring by the United States Government or any agency thereof. The views and opinions of authors expressed herein do not necessarily state or reflect those of the United States Government or any agency thereof. 


\section{EXECUTIVE SUMHARY}

The N-2 Group (Advanced Nuclear Technology) at Los A7amos National Laboratory (LANL) operates a variety of experimental reactors, each with a unique inventory of nuclear material. As part of the Safety Analys is Report for the Los Alamos Critical Experiment Facility (LACEF) at TA-18, a number of postulated bounding, or maximum consequence, accident scenarios were postulated. While not necessarily realistic in risk terms, these scenarios were designed to allow modeling of the approximate maximum radiological dose effects of accidents involving these experiments.

A computer modeling code, CRIT8, was written to allow prediction of the radiological doses to workers and members of the public resulting from these postulated maximum-effect accidents. The code accounts for the relationships of the initial parent radionuclide inventory at the time of the accident to the growth of radioactive daughter products, and considers the atmospheric conditions at time of release. The code then calculates a dose at chosen receptor locations for the sum of radionuclides produced as a result of the accident. Both criticality and non-criticality accidents are examined. 


\section{TABLE OF CONTENTS}

EXECUTIVE SUMMARY

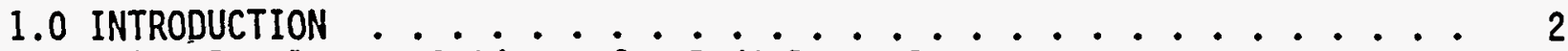

1.1 Regulatory Guidance for Radiological Dose Assessment . . . . . 2

1.2 Radionuclide Sources ............... 2

1.3 Receptor Locations

1.4 Calculational Considerations ............ 4

1.5 Summary of TA-18 Accidents Analyzed .......... . 6

2.0 DESCRIPTION OF THE CRIT8 DOSE ASSESSMENT MODEL . . . . . . 7

2.1 Model ing Goals ..................... 7

2.2 Model Overview ................. 8

2.3 Daughter Formation ................ 9

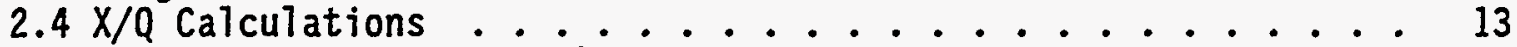

2.5 Packet Analysis Methodology ............... 14

2.6 Dose Assessment . . . . . . . . . . . . . 15

2.6.1 Air immersion Dose ............. 15

2.6.2 InhaTation Dose Assessment . . . . . . . . 16

2.6.3 Effective Dose Equivalent ............. 16

2.6 .4 Receptor Exposure Time ............. 17

2.7 Building Wake Cavity Effect ............. 17

3.0 CRIT8 DATA REQUIREMENTS ................... 20

3.1 The Profile Data File ................ 20

3.2 Radionuclide Inventories Analyzed ............. 20

3.3 Radioactive Decay Chain Data ............. 22

3.4 Dose Conversion Data ................ 22

3.4.1 Air immersion Dose Conversion .......... 22

3.4.2 Inhalation Dose Conversion ........... 23

3.5 Radionuclides Release Methodology ........... 23

3.6 X/Q Data Values ........................ 24

4.0 EFFECTIVE DOSE EQUIVALENTS FROM ACCIDENT SCENARIOS . . . . . . 27

5.0 HAND CALCULATION OF THE ACTIVITY AND DOSE CONTRIBUTION OF THE SELENIUM-89 DECAY SCHEME ................ 46

APPENDIX A DATA TABLES USED IN THE CRIT8 MODELING PROCESS . . . . . 47

Exfiltration Release Fractions for the Kiva 1 Facility . . . . . 48

Exfiltration Release Fractions for the Kiva 2 Facility . . . . . 48

Exfiltration Release Fractions for the Kiva 3 Facility 49

Exfiltration Release Fractions for the Sheba Building 49

Exfiltration Release Fractions for the Vault Facility . . . . . . 50

Unconfined Release Fractions for the Kiva 1 Facility ..... 50

List of Initial Radionuclide Inventory Used in the Fire Accident Scenario at Kiva 1.............. 50

List of Initial Radionuclide Inventory Used in the WINCO Collapse Accident Scenario .............. 51

List of Initial Radionucl ide Inventory Used in the SHEBA Accident Scenario
List of Initial Radionuclide Inventory Used in the Flattop Accident Scenario at Kiva 2............. 53 
List of Initial Radionuclide Inventory Used in the Godiva Accident Scenarios ..................... 54 List of Initial Radionuclide Inventory Used in the SKUA Accident

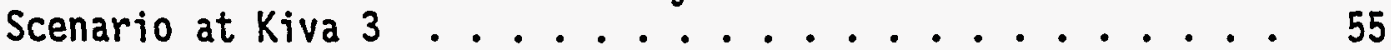
List of Initial Radionuclide Inventory Used in the vault $\dot{c} 017$ apse Accident Scenario .............. 56 Radionuclide Decay Data . . . . . . . . . . . . . . 57

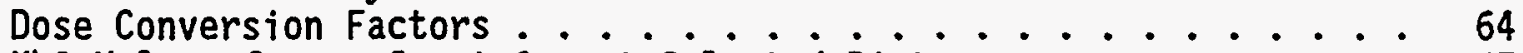
$X \backslash Q$ Values for an Inert Gas at Selected Distances ........ 67 XIQ values for Particulates at Selected Distances ........ 67 APPENDIX B HAND CALCULATION FOR THE SELENIUM-89 NUCLIDE $\ldots \ldots 68$ APPENDIX C REFERENCES ................... 80 


\section{LIST OF TABLES}

Table 1-1 Radiological Dose Assessment Guidance Documents . . . . . 3

Table 1-2. Radionuclide Release Fractions............ 4

Table 1-3 Receptor Locations for Evaluating Accident Effects ..... 5

Table 1-4 Summary of LACEF Accidents Analyzed . . . . . . . . 6

Table 2-1 Packet Exposure Fractions ............ 18

Table 2-2 Building Wake Cavity Correction Factors ........ 19

Table 3-1 Ratio of the Air Immersion Dose to Inhalation Dose for Short Lived Radionuclides .............. 24

Table 4-1 Summary of EDE's Calculated for TA-18 Postulated Accident

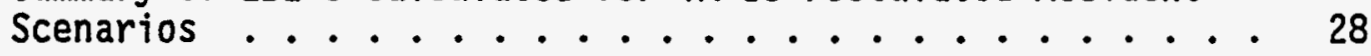




\section{LIST OF FIGURES}

Figure 2-1: CRIT8 Model Data Requirements and Functions . . . . . 10

Figure 3-1: Air Immersion DCF vs Gamma Energy Function . . . . . . 26

Figure 4-1: Receptor Total EDE's - Kiva 1 Collapse/Fire . . . . . 30

Figure 4-2: Pathway Contribution EDE's - Kiva 1 Collapse/Fire . . . . . 31

Figure 4-3: Receptor Total EDE's - SHEBA Excursion Accident . . . . . . 32

Figure 4-4: Pathway Contribution EDE's - SHEBA Excursion Accident . . . . 33

Figure 4-5: Receptor Total EDE's - Hillside Vault Collapse Accident . . . 34

Figure 4-6: Pathway Contribution EDE's - Hillside Vault Collapse

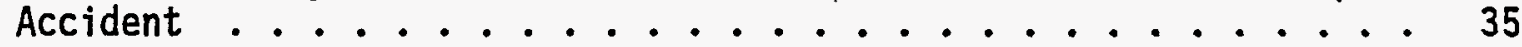

Figure 4-7: Receptor Total EDE's - WINCO Breech/Excursion Accident . . . 36

Figure 4-8: Pathway Contribution EDE's - WINCO Breech/Excursion

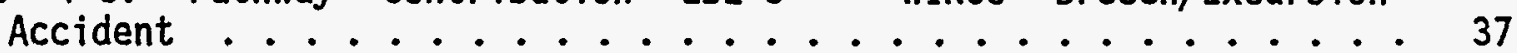

Figure 4-9: Receptor Total EDE's - GODIVA External Operation Accident . . 38

Figure 4-10: Pathway Contribution EDE's - GODIVA External Operation

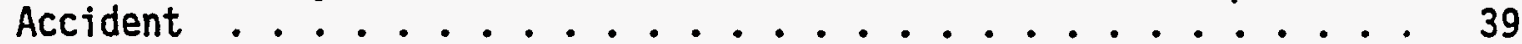

Figure 4-11: Receptor Total EDE's - FLATTOP Pu Excursion Accident . . . . 40

Figure 4-12: Pathway Contribution EDE's - FLATTOP Pu Excursion Accident - 41

Figure 4-13: Receptor Total EDE's - GODIVA Kiva 3 Excursion Accident . . 42

Figure 4-14: Pathway Contribution EDE's - GODIVA Kiva 3 Excursion Accident ..................... 43

Figure 4-15: Receptor Total EDE's - SKUA PU Vaporization Accident . . . . 44

Figure 4-16: Pathway Contribution EDE's - SKUA Pu Vaporization Accident . 45 


\section{EXECUTIVE SUMMARY}

The N-2 Group (Advanced Nuclear Technology) at Los Alamos National Laboratory (LANL) operates a variety of experimental reactors, each with a unique inventory of nuclear material. As part of the Safety Analysis Report for the Los Alamos Critical Experiment Facility (LACEF) at TA-18, a number of postulated bounding, or maximum consequence, accident scenarios were postulated. While not necessarily realistic in risk terms, these scenarios were designed to allow modeling of the approximate maximum radiological dose effects of accidents involving these experiments.

A computer modeling code, CRIT8, was written to allow prediction of the radiological doses to workers and members of the public resulting from these postulated maximum-effect accidents. The code accounts for the relationships of the initial parent radionuclide inventory at the time of the accident to the growth of radioactive daughter products, and considers the atmospheric conditions at time of release. The code then calculates a dose at chosen receptor locations for the sum of radionuclides produced as a result of the accident. Both criticality and non-criticality accidents are examined. 


\subsection{INTRODUCTION}

\subsection{ReguTatory Guidance for Radiological Dose Assessment}

The dose assessment methodology used in the calculation of radiological doses in the safety analysis are taken from DOE and NRC documentation applicable to the criticality facility. These govern issues of receptor locations, dose limit acceptance criteria, exposure pathways, dose conversion factors, nature of assumptions, and other criteria affecting the dose calculations.

Table 1-1 summarizes the guidance material used in calculating potential radiological effects resulting from postulated accidents at TA-18. Few of the guidance criteria provide explicit data values to be used when performing dose calculations. An exception to that are the dose conversion factor data provided in $\mathrm{DOE}$ (1988a and 1988b). For other data, the DOE Order calls for the selection of data such that when specific data is not available or is unknown, assumptions may be made which tend to maximize the resulting doses. Most important to these calculations are the meteorological data affecting air dispersion. Since specific meteorological conditions cannot be known in advance of an accident, conditions are assumed that result in doses that are maximized. Assumed conditions are judged to be representative of the local area.

\subsection{Radionuclide Sources}

Exposure from potential accidents may originate from two sources. Radionuclides may be produced in an accidental criticality during a routine laboratory test. Such an accident may result in various numbers of fissions of either plutonium or uranium depending upon the accident scenario. Over 900 unique isotopes are produced in a criticality, many of which are very short lived and do not contribute significantly to radiation exposure at locations downwind from the accident location. However, many of the original parents decay through several generations of radioactive daughters which may provide significant downwind exposure. A few of the radionuclides emerging from a criticality are gaseous, while most are high temperature volatilized particulates.

In both cases, the radionuclides are assumed to be instantly aerosolized into the laboratory room volume where the accident occurs. Whether this would actually happen depends on the specific energy deposited in the fissile fuel. For such accidents, the initial inventory of parent radionuclides is determined with the CINDER computer code by the LANL T-2 Group. Additional accidents were considered in which both plutonium and uranium, separately, are involved in a laboratory room fire. Those accidents are assumed to produce airborne radionuclides when bulk material burns (i.e., flameless oxidation). For those releases, release fractions are used to calculate the portion of bulk material subsequently released to the laboratory room as a result of burning. Table 1-2 summarizes the release fractions used in the analysis. 
Table 1-1

Radiological Dose Assessment Guidance Documents

Document

DOE Order 5480.12

DOE Order $6430.1 \mathrm{~A}$

DOE Order 5480.1A

DOE Order $6430.1 \mathrm{~A}$

NRC Reg. Guide 1.145
Applicable

Criteria

receptor location

dose conversion

factors

dose limit criteria

meteorological

parameters

engineered safety

features

exposure reduction for building wake cavity
Value(s)

point of unrestricted public access

effective dose equivalent(EDE)

25 rem effective dose equivalent

300 rem bone surface

$300 \mathrm{rem}$ thyroid

75 rem lung

150 rem any other organ

use dispersive parameters which tend to maximize the dose

- stability class F

- wind speed yielding

- greatest dose

allow no credit

reduction factor

of from $1.0-4.0$ 
Table 1-2

Radionuclide Release Fractions

\begin{tabular}{|c|c|c|}
\hline $\begin{array}{l}\text { Type of } \\
\text { Radionuclide }\end{array}$ & $\begin{array}{l}\text { Release } \\
\text { Fraction }\end{array}$ & Reference \\
\hline Inert Gases & 1.0 & Elder et al, 1986 \\
\hline $\begin{array}{l}\text { Bulk plutonium } \\
\text { during oxidation }\end{array}$ & 0.001 & Mishima, 1965 \\
\hline BuTk uranium & 0.001 & $\begin{array}{l}\text { Engineering judgement based } \\
\text { on plutonium release fraction }\end{array}$ \\
\hline $\begin{array}{l}\text { Uranium in } \\
\text { solution }\end{array}$ & 0.0005 & NRC, 1979 \\
\hline Iodine & 0.25 & Elder et a7, 1986 \\
\hline $\begin{array}{l}\text { A11 other } \\
\text { particulates }\end{array}$ & 0.01 & Elder et a1, 1986 \\
\hline
\end{tabular}

\subsection{Receptor Locations}

Receptor locations are the locations where humans are assumed to be in the event of an accident. Potential receptors can be either a member of the public or a laboratory employee. With respect to the DOE guidance, the public receptor location is at the point of unrestricted public access whether on-site (i.e., DOE/laboratory controlled land) or off-site.

That point has been determined by LANL to be on-site near Pajarito Road at distance of $1000 \mathrm{~m}$ from of TA-18. In addition to that location, another public receptor was selected at White Rock at the junction of Pajarito Road and State Highway 4, a distance of $4400 \mathrm{~m}$ from TA-18. The second public receptor location was evaluated to determine potential community impact following a TA-18 accident. An on-site worker receptor location was determined to exist $200 \mathrm{~m}$ from the TA-18 experimental facilities or kivas. Potential exposure to laboratory workers resulting from possible accidents were evaluated at that location. In all, three receptor locations are evaluated for each of eight accidents postulated to occur at TA-18. Table 1-3 summarizes the receptor locations.

\subsection{Calculational Considerations}

As described in Section 1.2, hundreds of potentially harmful radionuclides are produced in a criticality event. Although most of the initial parent nuclides decay away during transport to a receptor, the daughter nuclides may pose a significant exposure threat. The potential for exposure, be it by the parent inventory, the 
daughter inventory, or both, is primarily dependent on the time elapsed from time $=$ zero (the onset of the accident) to receipt at the receptor location.

As mentioned, the wind speed is not known in advance of an accident and, therefore, must be selected so as to result in a maximized dose. The wind speed selection should give consideration over a justifiable range of wind speed values consistent with local meteorological measurements. Los Alamos National Laboratory wind speed measurements at a mesa top location indicate that wind speeds never exceed about $6 \mathrm{~m} / \mathrm{s}$ during Pasquill stability class $-F$ ( $F$ stability is used since is the most conservative class). However, TA-18 is located at the canyon floor for which no meteorological data is available. The canyon floor may exhibit down canyon drainage winds during F-stability of greater speed than those experienced at the mesa top. To be conservative, a wind speed range of from $1.0-10.0 \mathrm{~m} / \mathrm{s}$ was determined to be an appropriate range of potential wind speeds at TA-18.

The effect of wind speed on the dose is unclear. Greater wind speeds have the effect of minimizing the transport time of the cloud of radionuclides, and thereby minimizing the decay time for the parent radionuclide inventory. Contrary to that effect, a greater wind speed al so has the effect of reducing the air concentration (see Section 2.4). Accident yield calculations by LANL have determined that none of the postulated accident scenarios have sufficient release energy to damage the assembly buildings. As a result, the release of aerosolized particulates from the laboratory occurs via an infiltration/exfiltration method through the cracks around doors and windows (described in section 2.5) and is also a function of wind speed. An increased wind speed has the effect of greatly increasing the exfiltration release from the laboratory room. Consequently, it is only possible to determine the maximizing wind speed by calculating the dose separately using different wind speeds. Given the great number of initial parent nuclides, the time-dependent ingrowth of daughter nuclides, the number of receptor distances (each of which may render a unique maximizing wind speed), and the number of possible wind speeds, a computer code was developed to calculate potential doses over a range of wind speeds and distances. The computer code is described in Section 2.0.

Table 1-3

Receptor Locations for Evaiuating Accident Effects Receptor Type Distance (m) Direction Location

site boundary

nearest population center

operations boundary
1000

4400

200 west

southeast off-site

southeast on-site 


\subsection{Surmary of TA-18 Accidents Analyzed}

A total of eight accident scenarios have been analyzed, with each scenario evaluated at three receptor distances for a total of 24 results. Table 1-4 summarizes the TA-18.accident scenarios analyzed.

Table 1-4

\section{Summary of LACEF Accidents Analyzed}

\begin{tabular}{|c|c|c|c|c|c|c|}
\hline Number & Name & Location & Description & $\begin{array}{l}\text { Material at } \\
\text { Release }\end{array}$ & Risk & $\begin{array}{l}\text { Building } \\
\text { Wake } \\
\text { Credit } \\
\text { Taken } \\
\end{array}$ \\
\hline 1 & Kiva fire & Kiva 1 & $\begin{array}{l}\text { Kiva collapse and } \\
\text { dispersion }\end{array}$ & Rapid & $\begin{array}{l}\text { Uranium } \\
\text { Particulates } \\
\text { U(93) solutiont }\end{array}$ & Ho \\
\hline 2 & WIHCO & Kiva 1 & $\begin{array}{l}\text { Accidental assembly } \\
\text { Uranium solution } \\
\text { excursion }\end{array}$ & Exfiltration & $\begin{array}{l}\text { Fission } \\
\text { Products } \\
U(5) \text { solutiont }\end{array}$ & Yes \\
\hline 3 & SHEBA & SHEBA & $\begin{array}{l}\text { Uranium solution } \\
\text { excursion }\end{array}$ & Exfitration & $\begin{array}{l}\text { Fission } \\
\text { Products }\end{array}$ & Yes \\
\hline 4 & FLATTOP & Kiva 2 & Plutonium excursion & Exfiltration & $\begin{array}{l}\text { Fission } \\
\text { Products and } \\
\text { P lutonium } \\
\text { Particulates }\end{array}$ & No \\
\hline 5 & XGODIVA & $\begin{array}{l}\text { Outside } \\
\text { Kiva } 2\end{array}$ & $\begin{array}{l}\text { Uranium metal } \\
\text { extreme excursion }\end{array}$ & Rapid & $\begin{array}{l}\text { Fission } \\
\text { Products and } \\
\text { Uranium } \\
\text { Particulates }\end{array}$ & No \\
\hline 6 & GOOIVA & Kiva 3 & $\begin{array}{l}\text { Uranium metal } \\
\text { extreme excursion }\end{array}$ & Exfiltration & $\begin{array}{l}\text { Fission } \\
\text { Products and } \\
\text { Uranium } \\
\text { Particulates }\end{array}$ & Yes \\
\hline 7 & SKUA & Kiva 3 & Plutonium excursion & Exfiltration & $\begin{array}{l}\text { Fission } \\
\text { Products and } \\
\text { Plutonium } \\
\text { Particulates }\end{array}$ & Yes \\
\hline 8 & Vault & $\begin{array}{l}\text { Hillside } \\
\text { Vault }\end{array}$ & $\begin{array}{l}\text { Building collapse } \\
\text { and dispersion }\end{array}$ & Exfiltration & $\begin{array}{l}\text { Uranium and } \\
\text { Plutonium } \\
\text { Particulates }\end{array}$ & No \\
\hline
\end{tabular}




\subsection{DESCRIPTION OF THE CRIT8 DOSE ASSESSHENT MODEL}

\subsection{Modeling Goals}

The accident scenarios considered in the accident safety assessment of TA-18 involve several hundred radionuclides, many of which are short lived and give rise to multiple generation daughter products. Given such a scenario, the relatively close distances to receptor locations, and the task of identifying the wind speed which renders a maximum dose, a computer code was developed with the capability of varying those parameters of interest. Specifications for the development of the code include:

- calculation of the dose via the air immersion and inhalation pathways

- use of the DOE dose conversion factors (DOE 1988a and DOE 1988b)

- variation of wind speed from one to $10 \mathrm{~m} / \mathrm{s}$

- calculating up to 4 th generation (i.e., greatgranddaughter) radionuclide ingrowth

- $\quad$ calculating up to $99 \%$ of the dose resulting from exposure to approximately 2000 initial parent and decay product radionuclides

- calculating doses at distances as close as $100 \mathrm{~m}$

- accommodating variations in the receptor exposure time

- calculating reduction in dose owing to the building wake cavity effect

- accommodating variations in the rate at which material is released from the TA-18 Taboratories following a possible accident

- in general, calculating maximum doses consistent with DOE guidance material

The last modeling goal pertains to a general conservatism and is reflected in the meteorological and dose assessment assumptions used in the analysis. For those calculations, the following assumptions are made:

- Pasquill stability class $F$ is used exclusively

- the ambient wind speed yielding the greatest dose is assumed, independently, for each accident 
- all releases are assumed to occur from the ground level

- all receptor locations are assumed to be along the centerline of the air dispersion plumes

The above assumptions provide for a conservative estimate (greater than expected) of dose assessment for each accident.

\subsection{Model Overview}

A computer program containing about 900 lines of code was developed for the TA-18 accident analysis. The code was developed using the Microsoft Quickbasic language and compiler to produce an MS-DOS stand-alone executable program. The compiled program requires about 10.0 minutes to fully execute the 10 wind speed iterations in the analysis. The program was designed for use in an IBM-PC/AT with an 80286 processor. Although special hardware or extra memory in not essential, a math co-processor and hard disk drive are highly recommended to avoid prolonged execution time.

The program performs two major functions, as illustrated in Figure 2-1. The first part of the program reads in large amounts of radionuclide and laboratory room release data from ASCII files. The data is reduced and stored in computer random access memory (RAM) in a manner designed for efficient data searches during program execution. The data files read by the program are:

(1) The profile data file contains information about the scenario such as scenario name, names of data files, the name of the output disk file, the receptor distance, the receptor exposure time, the time vs release fraction data, and the output print options. The profile data file is entered via an interactive prompt during program execution and contains a11 information and data file names required to run the code.

(2) The parent data file contains the list of initial radionuclide activities created in the accident which are released to the laboratory room. The activity of the parent represents the amount of activity after a bulk release fraction has been accredited. Parent radionuclide data is computed by the CINDER computer code and are unique inventories representative of specific materials and circumstances of the postulated criticality accident.

(3) The radionuclide decay data file which contains information about nuclide specific decay processes including daughter name(s), bi-modal decay fractions if pertinent, and half-lives. This file includes

data for both parent and ingrown radionuclides. The radionuclide decay scheme is discussed in more detail in Section 2.3.

(4) The dose conversion data file contains nuclide-specific dose conversion factor data for the air immersion and inhalation pathways. This

file includes data for both the parent and ingrown radionuclides. The dose conversion factor data is discussed in more detail in Section 2.6. 
(5) The $X / Q$ data file contains dose conversion factor data for both inert gas and particulate radionuclides. The values are calculated externally by the AIRDOS-EPA computer code (Moore et al, 1979) at selected distances. Using those data, the code then interpolates a $X / Q$ values for the current receptor distance. The $X / Q$ values are discussed in more detait in Section 2.4 .

The second part of the program uses the data to perform dose calculations in a calculational loop which increments the wind speed by $1.0 \mathrm{~m} / \mathrm{s}$ per iteration as illustrated in Figure 2-1. The underlying strategy of the code is:

(1) Increment the wind speed between one to $10 \mathrm{~m} / \mathrm{s}$.

(2) Calculate a decay time equal to the time required for the radionuclide cloud to arrive at the receptor location. That time is a function of both the delay time (i.e., time to escape the confines of the laboratory building containment) plus the plume travel time (i.e., receptor distance divided by wind speed). The delay time is discussed in more detail in section 2.6 .

(3) Calculate the residual parent and daughter radionuclide activities using the Bateman equations and decay time.

(4) Calculate a $X / Q$ value as a function of the wind speed, radionuclide type (i.e., inert gas or particulate), and receptor distance using the $X / Q$ data table.

(5) Calculate the air immersion and inhalation doses.

(6) Correct the doses for building wake cavity effect if applicable. This effect is discussed in more detail in Section 2.7.

(7) Go to step (1)

A more detailed description of the calculational methodology is contained in the remainder of this chapter.

\subsection{Daughter Formation}

The list of radionuclides analyzed contains many nuclides with short half-lives relative to the transport and confinement times required to convey the radionuclide cloud to a receptor location. The ingrowth of radioactive daughters from parents of high activity must be considered in the dose assessment.

Several of the initial parents decay through four or more generations of radioactive products on a time frame equivalent to the cloud transport time. The formation of daughter products is calculated in the CRIT8 code with a maximum fourth generation ingrowth. Fifth generation and greater decay products are not accounted for due to their greater calculational complexity. Any potential irradiation produced by the fifth or greater generation is not accredited in the dose calculation. However, 
CRIT8 MODEL DATA REQUIREMENTS

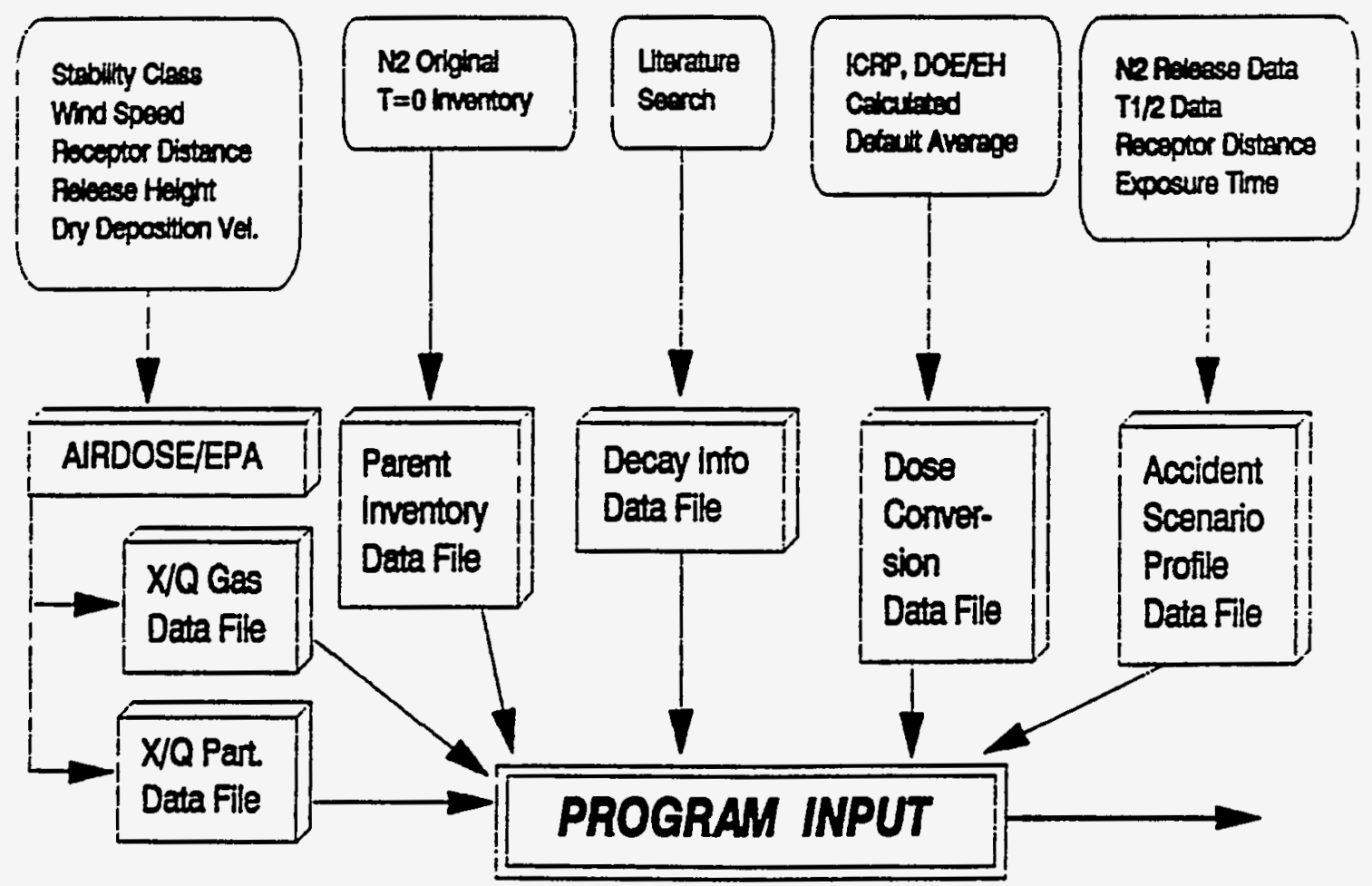

Continued...

Figure 2-1: CRIT8 Model Data Requirements and Functions 


\section{CRIT8 MAIN PROGRAM FUNCTIONS}

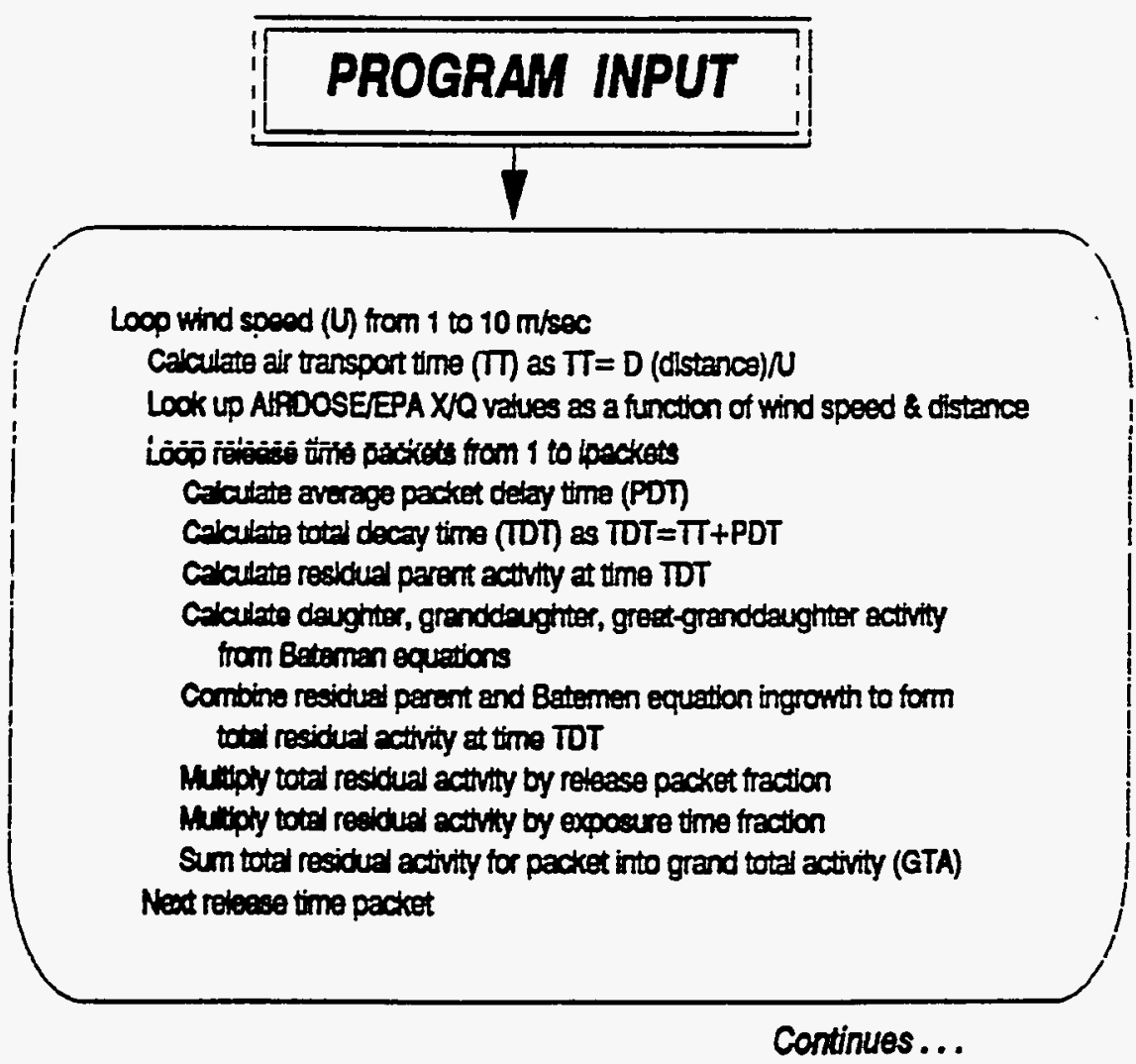




\section{CRIT8 MAIN PROGRAM FUNCTIONS}

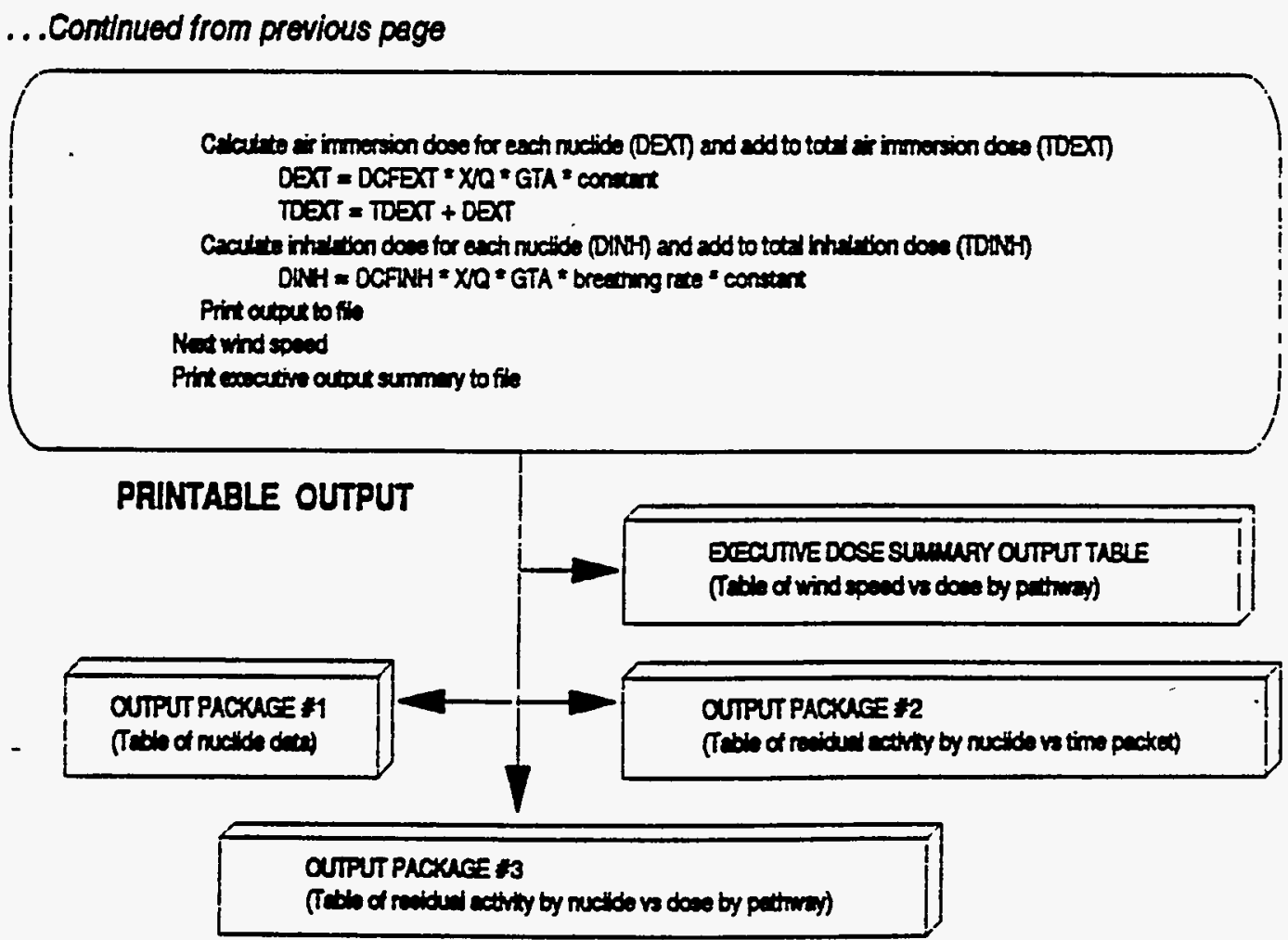


results have shown that the initial parent and first generation decay products are responsible for nearly all of the resulting dose.

The calculation of daughter ingrowth is performed using the Bateman equations (Friedlander et a7, 1981) which may be used to calculate any generation decay product given the initial parent inventory. Technically speaking, the Bateman equations calculate only the number of atoms of a given decay product:

$$
N_{i}=N_{p} \times f\left(t, T_{i}, l_{i-1}, l_{i-2}, \ldots, 1_{p}\right)
$$

where $N_{i}=$ Number of atoms of the ith generation nuclide,

$N_{p}=$ Number of atoms of the parent nuclide,

$T^{p}=$ decay constant ( 1 ambda)

$f()=$ function of time, $t$, and decay constants for the parent, daughter, granddaughter, etc. to the ith generation.

The complexity of $f()$ increases disproportionately as the generation increases. The relationship between activity and atoms is

$$
A=1 \times N
$$

where $N=$ Number of atoms

$A$ = Activity of the number of atoms

1 = decay constant

Combining the Bateman equation above with the definition of activity yields

$$
\begin{aligned}
& A_{i}=N_{i} \times 1_{i} \\
= & N_{p} \times f() \times 1_{i} \\
= & 1_{i} \times f() \times A_{p} / T_{p}
\end{aligned}
$$

where $A_{i}=$ Daughter activity

$$
\begin{aligned}
& A_{p}=\text { Parent activity } \\
& I_{i}=\text { Daughter decay constant } \\
& I_{p}=\text { Parent decay constant }
\end{aligned}
$$

Simply put, the daughter activity equals the parent activity times the ratio of the daughter to parent decay constants, times $f()$. The daughter activity acquires the units of Curies ( $\mathrm{C} i$ ) when the parent activity is expressed in $\mathrm{C} i$.

\section{$2.4 \times / 0$ Calculations}

The $X / Q(\mathrm{chi} / Q)$ value expresses the dispersion characteristics of the plume carrying the radioactive cloud. $X / Q$ is a function of many parameters including receptor distance, atmospheric stability, wind speed, release height, receptor location relative to the axis of the plume, and plume depletion effects. The $X / Q$ calculation in this analysis uses a standard Gaussian plume analysis: 
$X / Q=\frac{1}{P i \times S_{y} \times S_{z} \times U} \times D F$

where $X / Q=$ air concentration per unit source rate, $\mathrm{s} / \mathrm{m}^{3}$,

- $\mathrm{Pi}=3.142$

$S_{y}=$ Lateral dispersion coefficient, $m$,

$S_{z}=$ Vertical dispersion coefficient, $m$,

$U=$ Ambient wind speed, $\mathrm{m} / \mathrm{s}$,

DF = plume depletion fraction.

The above $X / Q$ equation models the dispersion as though the release occurs at ground level and places the receptor on the center axis of the plume. Both of those assumptions are conservative in that they result in a maximized air concentration. The dispersion coefficients, $S_{y}$ and $S_{z}$, are functions of downwind receptor distance and stability class, and increase with increasing distance and less stable atmospheric classes (i.e., Pasquill class A-C). The depletion fraction accounts for the effect of dry deposition, gravitational settiing, and precipitation scavenging. Of these, only dry deposition may be accredited in a conservative analysis. Dry deposition accounts for the chemical and mechanical attachment of radionuclides on surface vegetation, and is function of wind speed, stability class, and dry deposition velocity. The dry deposition velocity is a function of the particulates' chemistry and the local flora, although a more generic approach has been established and will be used in this analysis. The $X / Q$ values calculated by AIRDOS-EPA code (Moore et al, 1977) and used in this analysis are presented in Section 3.6

\subsection{Packet Anaiysis Methodology}

Once a postulated accident occurs, radionuclides are released to the laboratory room hosting the accident. In all but two accident scenarios analyzed, the laboratory room is not damaged or otherwise affected by the accident event. Consequently, the radionuclides inside the laboratory room have no direct path to the outside. For the most part, the material is contained in the laboratory. The only release is that which occurs via the infiltration-exfiltration of air through the cracks around doors and windows, or which otherwise permeates through the structure. Such a release is strongly dependent on the outside ambient wind speed. An exfiltration type room release requires significant time to occur and greatly affects the way in which room material is introduced into the air dispersion stream.

Section 3.5 provides a detailed description of the release curve calculational methodology. The methodology shows that the release fraction is a function of wind speed and that a decreasing fraction of room material is released to the outside as time progresses. Each building has its own characteristic release curve consistent with that building's construction and geometry. Release curves for the kivas and the hillside vault were computed using ASHRAE methodology by the $\mathrm{N}-2$ Group and supplied as inputs to CRIT8. From a given release curve, the total fraction of material may be integrated over a fixed period of time. The quantity of material released over such a period is a release packet and represents, in effect, the digitization of the release curve. A given scenario release is analyzed by breaking the release curve into a number of continuous sequential release packets each of which stipulates a fractional release of room material over a fixed period of time. 
Release fraction time intervals are chosen so that potential exposure from shorter lived radionuclides will not go unnoticed. For example, if a release of material were to occur over a 30 minute period, the radionuclide inventory averaged over 30 minutes would not contain short-lived radionuclides (i.e., half-lives less than a few minutes) since they would have decayed away. However, if the thirty minute release were divided into ten 3 -minute releases, the first release or packet would contain the short-lived radionuclides. Release packets are designed to be shorter at first and subsequently increase in duration as time progresses. Packets start at about one minute in duration (midpoint at 30 seconds) since a minimum decay time of at least 20 seconds $(200 \mathrm{~m}$ minimum receptor distance at $10 \mathrm{~m} / \mathrm{s}$ wind speed) are anticipated. Tables A-1 through A-6 summarize the release packets used for the accident analysis.

For the purposes of dose assessment, the exposure time to the radioactive release never exceeds 120 minutes by definition. Therefore, releases occurring after 120 minutes has elapsed are of no interest.

\subsection{Dose Assessment}

The radiation dose assessment presented in this analysis utilizes the methodology promulgated in DOE Order 5480.1a, and DOE (1988a and 1988b). Fifty-year committed effective dose equivalents (CEDE) are calculated for both internal and external exposures via the airborne pathway. All the doses presented in this analysis occur as a result of a calculated release of radioactivity from a postulated accident. Potential contributions to the accident dose include only exposure modes which are unavoidable following the accident. This includes radiation doses acquired via the inhalation and air immersion pathways only. Doses resulting from ingestion of contaminated food or water, or prolonged exposure to radionuclides deposited on the ground are precluded as part of the facility's post accident emergency preparedness plans following an accidental release.

\subsubsection{Air Immersion Dose}

The air immersion dose calculated for a given accident scenario is the sum of air immersion doses over all nuclides

$$
D_{\dot{a}}=\operatorname{SUM}_{i}\left(D_{a_{i}}\right)_{i}
$$

where $D_{w} \quad=$ Total air immersion dose summed over al1 nuclides, rem, $\left(D_{\mathrm{ai}}\right)_{i}=$ Air immersion dose from the ith nuclide, rem.

The air immersion dose calculated for an individual radionuclide is

$$
\left(D_{s i}\right)_{i}=A_{i} \times(X / Q)_{i} \times D C F_{i} \times\left(1 \times 10^{6}\right) \times\left(1 \times 10^{-6}\right) \times\left(2.78 \times 10^{-4}\right)
$$


where $A_{i 1}=$ Activity of the ith nuclide arriving at the receptor location, $\mathrm{Ci}$,

$$
\begin{aligned}
& (X / Q)_{i}=\quad \begin{array}{l}
X / Q \text { for the ith nuclide calculated at the receptor } \\
\text { distance, } \mathrm{s} / \mathrm{m}^{3},
\end{array} \\
& D C F_{i}=\quad \begin{array}{l}
\text { Air immersion dose conversion factor for the ith } \\
\text { nuclide, rem- } \mathrm{cm}^{3} / \mathrm{uCi}-\mathrm{hr},
\end{array} \\
& 1 \times 10^{6}=\quad \mathrm{UCi} / \mathrm{Ci}, \\
& 1 \times 10^{-6}=\quad \mathrm{cm}^{3} / \mathrm{m}^{3}, \\
& 2.78 \times 10^{-4}=\mathrm{s} / \mathrm{hr} .
\end{aligned}
$$

The air immersion dose conversion factor data is discussed in more detail in section 3.3 .

\subsubsection{Inhalation Dose Assessment}

The inhalation dose calculated for a given accident is scenario is the sum of inhalation doses over all radionuclides

$$
D_{i}=\operatorname{SUM}_{j}\left(D_{j}\right)
$$

where $D_{i}=$ Total inhalation dose summed over all nuclides, rem,

$D_{j}=$ Inhalation dose from the jth nuclide, rem.

The inhalation dose calculated for the $j$ th nuclide is

$$
D_{j}=A_{j} \times(X / Q)_{j} \times D C F_{j} \times B R \times\left(1 \times 10^{6}\right)
$$

where $A_{j}=$ Activity of the $j$ th nuclide arriving at the receptor location, $\mathrm{Ci}$,

$$
\begin{aligned}
& (X / Q)_{j}=\begin{array}{l}
X / Q \text { for the } j \text { th nuclide calculated at the receptor } \\
\text { distance, } s / \mathrm{m}^{3},
\end{array} \\
& D C F_{j}=\quad \begin{array}{l}
\text { Inhalation dose conversion factor for the } j \text { th nuclide, } \\
\text { rem/uCi, }
\end{array} \\
& B R=\text { Standard man breathing rate, } 3.4 \times 10^{-4} \mathrm{~m}^{3} / \mathrm{s}, \\
& I \times 10^{6}=\mathrm{uCi} / \mathrm{Ci} .
\end{aligned}
$$

\subsubsection{Effective Dose Equivalent}

The calculation of the 50-year committed effective dose equivalent (EDE) is the 
sum of the external air immersion dose and the internal inhalation dose, although the external dose is, in effect, not a true 50-year committed dose since exposure occurs only during the passage of the radioactive cloud. With the inhalation dose, bodily exposure continues, in the EDE model, over 50 years or until the radionuclide(s) are removed through biochemical or radioactive decay processes. In any event, the EDE model calculates a time-integrated absorbed dose that does not exceed 50 years of bodily irradiation. Both the external and internal conversion factors result in an effective dose equivalent defined in the ICRP publication 30 (ICRP, 1978) as a weighted dose calculated for 12 critical organs of the body. Summing both the external and internal EDE's together results in a meaningful total EDE expressing the combined effects of both internal and external exposure. Dose conversion factors used in this analysis are discussed further in Section 3.4 .

\subsubsection{Receptor Exposure Time}

The dose equations presented above assume that the receptor is present during the entire passage of the radionuclide cloud. In many of the accident scenarios analyzed, this assumption is invalid and a partial exposure based on limited exposure time must be calculated. Given the packet methodology employed for calculating the room release, the exposure time is implemented by assigning an exposure fraction to each packet. The packet exposure fraction represents the fraction of packet material to which the receptor is exposed. Table 2-1 summarizes the exposure fractions for the accident scenarios.

For the confined release scenarios at $200 \mathrm{~m}$ downwind distance, a 30 minute exposure time was evaluated. From Table A-1, for the first accident scenario, the first packet releases material over a one minute period. The packet exposure fraction is 1.0 since the receptor will be present for 30 minutes, longer than the duration of the first packet. The second packet also lasts one minute. The total expired time is now two minutes and the packet exposure fraction for the second packet will also be 1.0. Similarly, the next five packets' exposure fraction is 1.0 . However, the eighth packet occurs after 30 minutes has elapsed and since the receptor has only 30 minutes of exposure, the packet exposure fraction is 0.0 . All other subsequent packets exposure fractions are 0.0 since the receptor is gone. If exposure is terminated in the middle of a packet an appropriate fraction between 0.0 and 1.0 is calculated.

The dose is evaluated by calculating a separate independent dose for each packet. Packet doses vary by virtue of the decay time used to calculate to packets' activity. Each packet dose is then multiplied by the packet exposure fraction to yield a packet dose corrected for exposure time. The corrected doses are summed over all packets to yield the cumulative dose.

\subsection{Building Wake Cavity Effect}

The presence of a building or structure near the location of an air effluent can have a significant impact on the effluent air concentrations downwind. The structure has the effect of dispersing the effluent material before it actualiy enters the airstream. Several of the effects of the accident scenarios are mitigated by the presence of the laboratory structures hosting the accident. 
The effects of the building wake cavity is documented in NRC, 1983. That methodology is used in these analysis to assess the potential air concentration reduction owing to the structure. The regulatory guide contains a correction factor which may be applied to conventional $X / Q$ values calculated using the methods described in section 2.5. Since both inhalation and air immersion doses are directly proportional to the $X / Q$ value, the building wake correction factor may be directly applied to the uncorrected doses.

The correction factor as described in the NRC Regulatory Guide 1.145, is a function of both wind speed and atmospheric stability class. As described in Section 3.5 , the F-stability class is used exclusively for the accident analysis. Table 2-2 lists the building wake correction factors by wind speed for the F-stability class. Correction factors range from a maximum of 4.0 at a wind speed of $1 \mathrm{~m} / \mathrm{s}$ to 1.4 at 5 $\mathrm{m} / \mathrm{s}$. At greater wind speeds, the correction factor is 1.0 and the building wake cavity has no effect. Table 1-4 describes the TA-18 accident doses and indicates whether a building wake correction factor is applicable in each.

\section{Table 2-1}

\section{Packet Exposure Fractions}

\begin{tabular}{|c|c|c|c|c|c|c|c|c|c|c|c|}
\hline $\begin{array}{l}\text { Type } \\
\text { Release }\end{array}$ & $\begin{array}{c}\text { Receptor } \\
\text { Distance } \\
\text { (m) }\end{array}$ & 1 & 2 & 3 & 4 & $\begin{array}{c}\text { cket } \\
5 \\
\end{array}$ & $\begin{array}{c}\text { Number } \\
6 \\
\end{array}$ & 7 & 8 & 9 & 10 \\
\hline Confined & $\begin{array}{r}200 \\
1000 \\
4400\end{array}$ & $\begin{array}{l}1.0 \\
1.0 \\
1.0\end{array}$ & $\begin{array}{l}1.0 \\
1.0 \\
1.0\end{array}$ & $\begin{array}{l}1.0 \\
1.0 \\
1.0\end{array}$ & $\begin{array}{l}1.0 \\
1.0 \\
1.0\end{array}$ & $\begin{array}{l}1.0 \\
1.0 \\
1.0\end{array}$ & $\begin{array}{l}1.0 \\
1.0 \\
1.0\end{array}$ & $\begin{array}{l}1.0 \\
1.0 \\
1.0\end{array}$ & $\begin{array}{l}0.0 \\
0.0 \\
1.0\end{array}$ & $\begin{array}{l}0.0 \\
0.0 \\
1.0\end{array}$ & $\begin{array}{l}0.0 \\
0.0 \\
1.0\end{array}$ \\
\hline iconfined & $\begin{array}{r}200 \\
1000 \\
4400\end{array}$ & $\begin{array}{l}1.0 \\
1.0 \\
1.0\end{array}$ & $\begin{array}{l}1.0 \\
1.0 \\
1.0\end{array}$ & $\begin{array}{l}1.0 \\
1.0 \\
1.0\end{array}$ & $\begin{array}{l}1.0 \\
1.0 \\
1.0\end{array}$ & $\begin{array}{l}N A \\
N A \\
N A\end{array}$ & $\begin{array}{l}N A \\
N A \\
N A\end{array}$ & $\begin{array}{l}\text { NA } \\
N A \\
\text { NA }\end{array}$ & $\begin{array}{l}\text { NA } \\
\text { NA } \\
\text { NA }\end{array}$ & $\begin{array}{l}\text { NA } \\
\text { NA } \\
\text { NA }\end{array}$ & $\begin{array}{l}\text { NA } \\
\text { NA } \\
\text { NA }\end{array}$ \\
\hline
\end{tabular}

NA = Not applicable. Unconfined releases use only four release packets. 
Table 2-2

Building Wake Cavity Correction Factors'

\begin{tabular}{cc} 
Wind Speed $(\mathrm{m} / \mathrm{s})$ & Correction Factor ${ }^{2}$ \\
\hline 1.0 & 4.0 \\
2.0 & 4.0 \\
3.0 & 2.6 \\
4.0 & 1.8 \\
5.0 & 1.4 \\
6.0 & 1.0 \\
7.0 & 1.0 \\
8.0 & 1.0 \\
9.0 & 1.0 \\
10.0 & 1.0
\end{tabular}

1 - Source, NRC, 1983.

2 - Calculated for Pasquill stabitity class-F, onty. 


\subsection{CRIT8 DATA REQUIREMENTS}

A number of data are required to run the CRIT8 code. These data inciude specific radionuclide data relating to radioactive decay, source terms, and dose conversion factors. In addition, detailed data is required which describes the release of material from a laboratory room via the infiltration-exfiltration process. Also, specific $X / Q$ data tables are imported into CRIT8 from the AIRDOS-EPA code. Lastly, discrete data items such as receptor distance and exposure times must be specified. All data are contained in data files that reside externally to the CRIT8 executable code.

\subsection{The Profile Data File}

The profile data file is an executive file which contains the name of the scenario, the names of all data files to be called, output file names and options, and the receptor distance and exposure time. When the CRIT8 code executes it responds by prompting the user for the profile data file name.

\subsection{Radionuclide Inventories Analyzed}

A criticality event creates an initial inventory of over 900 radionuclides. Many of the initial radionuclides quickly decay, at least in part, into daughter, granddaughter, great-granddaughter, etc., decay products. After a relatively short period of time, the number of radionuclides present will increase to several thousand. Such a large number of radionuclides must be supported by an equally long list of support data described in section 2.1. Computer RAM constraints and potentially long code execution time imposed by the PC environment make it imperative to reduce the initial number of parent nuclides to those which contribute most to the resulting doses.

The initial activities of the parent inventory vary over many orders of magnitude. Ideally, an index of relative dose contribution could be formed as the product of initial activity and dose conversion factor since those are the only nuclide specific variations contained in the dose equation (see section 2.7). However, a criticality event results in uncommon radionuclides, most of which are not included in the dose conversion factors references (DOE, 1988a and DOE, 1988b) used in this anatysis. Therefore, for the purposes of eliminating the majority of parent radionuclides which contribute very little to the overall dose, the following assumptions are made:

(1) For the external exposure pathway, the radionuclides contributing most are ranked by initial parent activity. Parent radionuclides of greatest activity are retained until a level of $99 \%$ of the total initial activity is accounted for.

(2) For the internal pathway, the inhalation dose is insignificant compared with the air immersion dose for radionuclides with halflives less than one hour, and may, therefore, be disregarded (i.e., inhalation dose conversion factor value of 0.0 ). For radionuclides of half-life greater than one hour, virtually all dose conversion 
factors are found in the reference material. Consequently, alt parent radionuclides are retained if their half-lives are greater than one hour.

The first assumption reduces the number of initial parent radionuclides from more than about 900 nuclides to about 100 nuclides. The 100 or so nuclides retained account for over $99 \%$ of the initial activity of the original 900 initial parents. Note that all actinides present in the initial inventory are retained, regardless of their activity.

To justify the elimination of approximately 800 radionuclides, it is assumed that the eliminated radionuclides have air immersion dose conversion factors equal to the maximum (i.e., $-1 \times 10^{4} \mathrm{mrem}-\mathrm{m}^{3} / \mathrm{uCi}-\mathrm{hr}, \mathrm{DOE}, 1988 \mathrm{a}$ ). The relative dose contribution is the product of dose conversion factor and activity. The eliminated nuclides have a maximum activity of less than about $100 \mathrm{Ci}$ so that the relative dose contribution has a maximum of about $1 \times 10^{4} \times 100 \mathrm{Ci}$ or $1 \times 10^{8}$. On the other hand, the maximum retained radionuclides have activities greater than about $1.0 \times 10^{5} \mathrm{C} i$ with a dose conversion factor of about $1.0 \times 10^{4}$ (i.e., $\mathrm{Kr}-90$ ). The maximum hazard product is then $1.0 \times 10^{5} \mathrm{Ci}$ $x 1.0 \times 10^{4}$ or $1.0 \times 10^{9}$. Consequently, dose contributions from the eliminated radionuclides is at lease three order of magnitude less than those for the maximum contributors, and may be safely eliminated.

While the initial parent radionuclides may be eliminated in the above argument, the potential for particularly bad daughter formation from eliminated parent radionuclides is possible. However, the potential daughter threat can only exist from daughter nuclides which are harmful as internally deposited radionuclides (i.e., those with high inhalation dose conversion factors). Therefore daughters formed by a parent with a maximum of $100 \mathrm{Ci}$ or less initial activity would be of insufficient activity to produce significant external exposure.

The potential inhalation dose from a daughter product is greatest when the daughter happens to be a long-lived alpha emitting radionuclide. Inhalation dose conversion factors are greatest for radionuclides with half-lives greater than about 100 years. A daughter formed from a maximum of $100 \mathrm{Ci}$ of a parent of half-life of one hour or less will yield a maximum of about $1.0 \times 10^{-3} \mathrm{Ci}$ of daughter product. Although many significant alpha/beta inhalation nuclides display half-lives less than 100 years and would, in the example above yield greater daughter activities, their inhalation dose conversion factors would necessarily be lower by virtue of their shorter halflives. It can be shown that the dose resulting from the inhalation of the daughter will be much less than the air immersion dose resulting from exposure to the $99 \%$ activity of the initial parents retained.

In summary, the approximately 900 initial parent radionuclides created during a postulated criticality event are reduced to about 100 radionuclides. The shortened list contains the most active radionuclides which together account for over $99 \%$ of the total activity. In addition, the shortened list contains all radionuclides with half-lives greater than one hour. From the discussion above, the shortened list will result in internal and external doses that are equivalent in magnitude to those that would be calculated using the long list of about 900 radionuclides.

The name and activity of the initial significant radionuclides must be specified 
in the parent inventory file. The code can accommodate up to 375 radionuclides including parent and daughter nuclides. Since each parent gives rise to from two to three daughters, no more than about 100 initial parents should be specified.

The initial list of radionuclides is generated by the CINDER code in LANL's T-2 Group. CINDER generates a unique set of initial parent radionuclides for a criticality event incorporating specific user defined characteristics of the event. That 7 ist is shortened to the most significant totaling from about 80 to 100 radionuclides depending on the accident scenario. Tables A-7 through A-13 summarize the short list of initial parents for each accident scenario. As discussed in section 2.3, the short lists contain about $99 \%$ of the initial beta/gamma activity and $100 \%$ of all radionuclides with half-lives greater than one hour, plus all actinides. Maximum activities occur for the krypton, bromine, and xenon isotopes at levels of several hundreds of thousands of $\mathrm{Ci}$. Minimum retained activities are generally in the range of $100 \mathrm{Ci}$ and greater.

\subsection{Radioactive Decay Chain Data}

Each parent radionuclide and future daughter radionuclide name must be specified in the decay data file. Each name is accompanied by that nuclide's half-life, decay daughter(s), and the fractional component along each decay path in the event of bimodal decay. These data form a large data file whose name is entered into the profile data file. Table A-14 summarizes the data contained in the decay data file.

\subsection{Dose Conversion Data}

Dose conversion factors are used to convert the exposure received by a receptor into a radioactive dose measured in units of rem. Each radionuclide has unique dose conversion factors depending upon its own individual decay energies, half-life, and biochemical properties. Two dose conversion factors, air immersion and inhalation, are required for each parent and daughter radionuclide in these analysis.

Dose conversion factors calculated using the ICRP 26/30 methodology are required for performing DOE dose assessments. A partial list of dose conversion factors are provided in DOE, 1988. However, a criticality event generates many uncommon radionuclides for which dose conversion factors are not available. The remainder of this section describes the methodology used in selecting dose conversion factors for uncommon radionuclides. Dose conversion factors used in this analys is are presented in Tabie A-15.

\subsubsection{Air immersion Dose Conversion}

Approximately 350 radionuclide parents and daughters are analyzed in these studies. Of those only about $20 \%$ are referenced in the DOE dose conversion factor (DOE, 1988a and DOE, 1988b) documentation and/or ICRP 26/30 (ICRP, 1978) source materia7. The remaining radionuclides were either assigned a dose conversion factor according to its characteristic gamma energy, or in the case of a radionuclide for which no gamma energy data is available, assigned a value equal to the average air immersion dose conversion factor. The gamma energy method is preferable but many of the radionuclides are so uncommon that not even that information is available. 
For radionuclides listed in DOE, 1988a reference, gamma energy functions were plotted against their air immersion dose conversion factors. The gamma energy function is the sum of the discrete gamma energies times its relative intensities. The gamma function data was taken from Gusev et a1, 1979. The gamma functions vs air immersion dose conversion factor is plotted in figure 3-1 and demonstrates a reasonable correlation of data. From the correlation, air immersion dose conversion factors were calculated for radionuclides not contained in DOE, 1988 by multiplying the gamma function by 48.2 . Radionuclides not contained in DOE, 1988a and with gamma energies not found in Gusev et a1, 1979 were assigned a dose conversion factor of $4000 \mathrm{mrem}-\mathrm{m}^{3} / \mathrm{uCi}$ $y r$. That average was made over a set of short-lived radionuclides contained in DOE, 1988, having atomic numbers 1 ess than 150, similar to the radionuclides having no gamma energy data.

\subsubsection{Inhalation Dose Conversion}

As with the air immersion dose conversion factors, only a small percentage of the radionuclides analyzed are referenced in the DOE, 1988 documentation 1 isting inhalation dose conversion factors. However, nearly al1 of the radionuclides not listed possess radioactive half-lives that are less than one hour. That characteristic suggests that the inhalation dose may be insignificantly small compared with a nuclides external air immersion dose. Table 3-1 summarizes a plot of the ratio of the air immersion dose to the inhalation dose for a random sample of radionuclides posing both half-lives less than one hour and dose conversion factors listed in DOE, 1988b. Those data indicate that the ratio of doses falls between about 10 and 50 . Consequent7y, the inhalation dose conversion factor is assumed to be zero for all beta-gamma emitting radionuclides with half-lives less than one hour. That assumption implies that the dose is adequately represented by the air immersion dose. Inhalation dose conversion factors for radionuclides posing half-lives greater than one hour were found in DOE, 1988b and used in the dose calculations.

Lung clearance classes categorize internal dose conversion factors for a given radionuclide according to the nuclide's chemical form. Up to three sets of dose conversion factors are provided in DOE, $1988 \mathrm{~b}$ per radionuctide. In general, the chemical form yielding the greatest dose conversion factor is used. The only exception to this method occurs for plutonium. When bulk plutonium oxidizes, plutonium dioxide particulates are formed which have a lung clearance class of years (class $Y$ ), (NRC, 1983). For oxide forms of plutonium, the inhalation dose conversion factors are less than for other chemical forms of plutonium as referenced in DOE, 1988b. Inhalation dose conversion factors presented in Table A-15 pertain to oxide forms of plutonium only.

\subsection{Radionuclides Release Methodology}

Several of the accident scenarios addressed result in radionuclide releases into one of several possible laboratory rooms. The room material is subsequently released to the outside either by the infiltration-exfiltration process or released directly through a breach in the building structure. The infiltration-exfiltration process is the normal exchange of room air that occurs through the cracks around doors and windows, or that which, otherwise, permeates through the structure. Nearly all structures exhibit some degree of air infiltration from the outside resulting in a slow 
exchange of air with the outside. The rate of exchange is strongly related to the outside ambient wind speed. Tables A-1 through A-6 summarizes the accident analysis release fractions calculated for each release packet as a function of wind speed.

\section{Table 3-1}

Ratio of the Air immersion Dose to Inhalation Dose for Short Lived Radionuclides ${ }^{1}$

\begin{tabular}{|c|c|c|c|c|}
\hline $\begin{array}{l}\text { Radio- } \\
\text { Nuclide }\end{array}$ & $\begin{array}{l}\text { Air immersion } \\
\text { Dose Conversion } \\
\text { Factor } \\
\text { (mrem-m3/ } \\
u C i-y r) \\
\end{array}$ & $\begin{array}{l}\text { Inhalation } \\
\text { Dose Conversion } \\
\text { Factor } \\
\text { (rem/ } \\
\text { uCi) }\end{array}$ & $\begin{array}{l}\text { Ratio } \\
\text { Air immersion } \\
\text { to } \\
\text { Inhalation } \\
\text { Dose }\end{array}$ & $\begin{array}{l}\text { Half }-1 \text { ife } \\
\text { (min) }\end{array}$ \\
\hline $\begin{array}{l}\mathrm{Ba}-141 \\
\mathrm{Ba}-142 \\
\mathrm{Br}-84 \\
\mathrm{C} s-138 \\
\mathrm{I}-134 \\
\mathrm{Mo}-101 \\
\mathrm{Pr}-144 \\
\mathrm{Pr}-147 \\
\mathrm{Rb}-88 \\
\mathrm{Rb}-89 \\
\mathrm{Rh}-103 \mathrm{~m} \\
\mathrm{TC}-101 \\
\mathrm{Te}-131 \\
\mathrm{Te}-134 \\
\mathrm{Y}-91 \mathrm{~m}\end{array}$ & $\begin{array}{l}4.59 E+03 \\
4.67 E+03 \\
1.02 E+04 \\
1.27 E+04 \\
1.38 E+04 \\
7.94 E+03 \\
1.79 E+02 \\
3.84 E+03 \\
3.58 E+03 \\
1.14 E+04 \\
9.99 E-01 \\
1.73 E+03 \\
2.16 E+03 \\
4.44 E+03 \\
2.68 E+03\end{array}$ & $\begin{array}{l}7.40 E-05 \\
3.60 E-05 \\
8.70 E-05 \\
8.80 E-05 \\
1.10 E-04 \\
3.60 E-05 \\
4.20 E-05 \\
2.70 E-05 \\
8.00 E-05 \\
3.70 E-05 \\
4.60 E-06 \\
1.60 E-05 \\
9.90 E-05 \\
1.00 E-04 \\
3.10 E-05\end{array}$ & $\begin{array}{l}5.78 E+00 \\
1.21 E+01 \\
1.09 E+01 \\
1.35 E+01 \\
1.17 E+01 \\
2.06 E+01 \\
3.97 E-01 \\
1.33 E+01 \\
4.17 E+00 \\
2.87 E+01 \\
2.02 E-02 \\
1.01 E+01 \\
2.03 E+00 \\
4.14 E+00 \\
8.06 E+00\end{array}$ & $\begin{array}{l}1.83 E+01 \\
1.07 E+01 \\
3.18 E+01 \\
3.34 E+01 \\
5.26 E+01 \\
1.46 E+01 \\
1.73 E+01 \\
1.20 E+01 \\
1.78 E+01 \\
1.54 E+01 \\
5.61 E+01 \\
1.42 E+01 \\
2.50 E+01 \\
4.18 E+01 \\
4.97 E+01\end{array}$ \\
\hline
\end{tabular}

1 - Half-lives are less than 60.0 minutes.

2 - Source, DOE, 1988a.

3 - Source, DOE, 1988b.

\section{$3.6 \times 10$ Data Values}

Calculation of the $X / Q$ values was performed using the AIRDOS-EPA computer code (Moore et a], 1979) by selecting AIRDOS-EPA input values to represent the scenario described above. Two groups of $X / Q$ values were calculated:

(1) Particulates $X / Q$ values which use a dry deposition velocity of $0.0018 \mathrm{~m} / \mathrm{s}$ as suggested by Moore et aT, 1979

(2) Inert gas $X / Q$ values which use a dry deposition velocity of 0 .

The inert gases in these analysis are confined to isotopes of krypton, bromine, xenon, 
and iodine. Inert gases result in air concentrations that are higher than particulate concentrations since material is not removed during plume transport. Although iodine is not an inert gas, its reactivity in the atmosphere is not well known and it is conservative, therefore, to treat iodine as an inert gas.

Tabies $A-16$ and $A-17$ summarize the $X / Q$ values used in these analysis. The $X / Q$ values were calculated by the AIRDOS-EPA code at selected downwind distances ranging from $100 \mathrm{~m}$ to $10,000 \mathrm{~m}$. At distances 7 ess than $100 \mathrm{~m}$ the equations describing the dispersion coefficients become invalid, while $10,000 \mathrm{~m}$ represents a practical upper bound to the receptor distances needed. User defined receptor distances which fall outside that range will be rejected by the CRIT8 code during execution. Any distance that falls within the range is acceptable and CRIT8 will interpolate a $X / Q$ value using the distances and $X / Q$ values provided in table $A-16$ and $A-17$. 


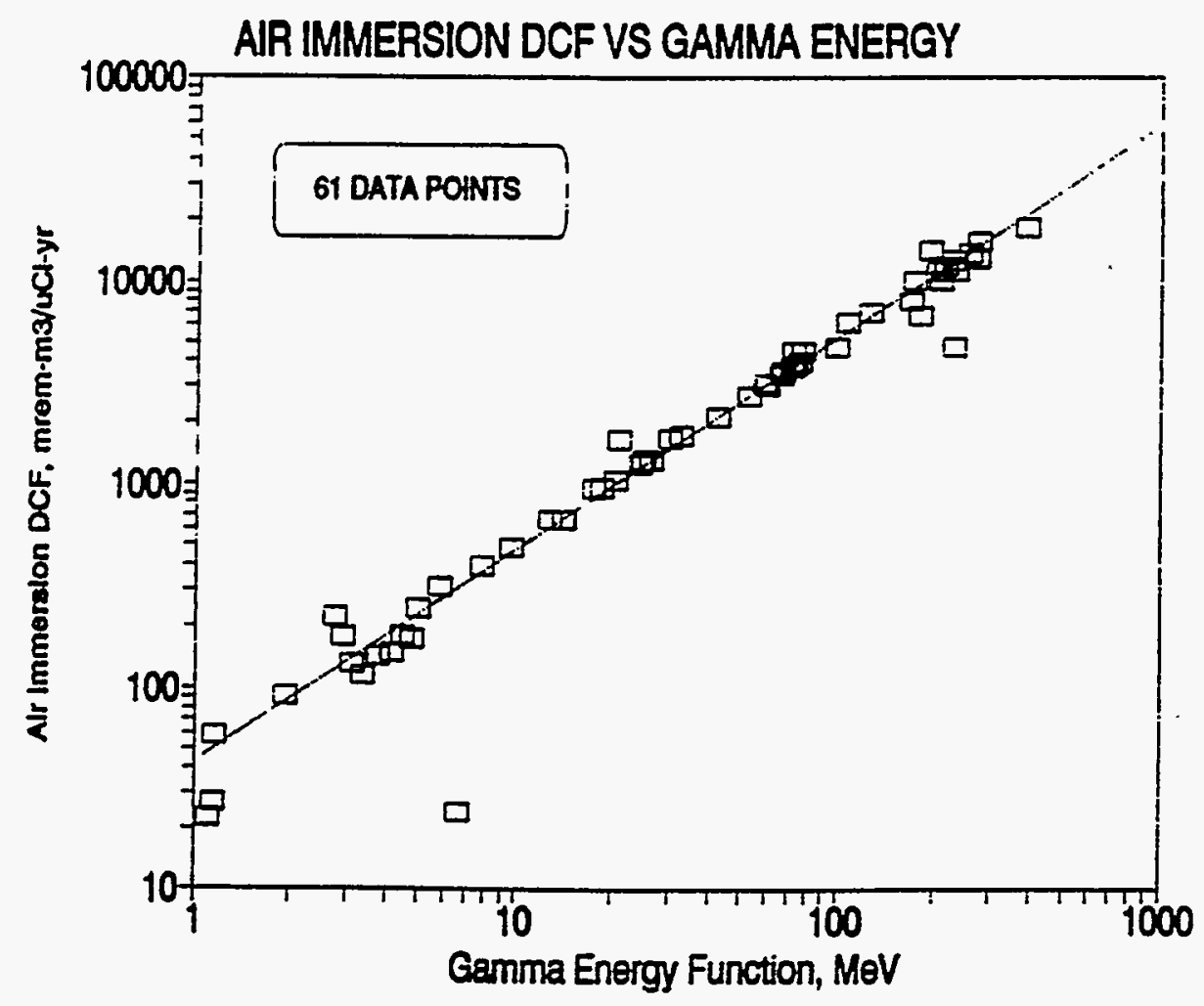

Figure 3-1: Air Immersion DCF vs Gamma Energy Function 


\subsection{EFFECTIVE DOSE EQUIVALENTS FROM ACCIDENT SCENARIOS}

Effective dose equivalents were calculated for each accident scenario summarized in table 1-4 at each of three receptor distances summarized in table 1-3 for a total of 24 dose results. Those results are summarized in table 4-1 together with the significant exposure pathway and most significant radionuclides contributing to the fina] EDE. Figures 4-1 through 4-16 summarize dose results and pathway contribution for each accident scenario.

The greatest dose occurred for XGODIVA accident scenario with a calculated EDE of 43.5 rem at $200 \mathrm{~m}$ primari7y from an external exposure to $\mathrm{Rb}-90$, a daughter of $\mathrm{Kr}-90$ and granddaughter of $\mathrm{Br}-90$, which are both very 7 arge activities in the initial parent inventory. The second greatest dose occurred for the SKUA accident with an EDE of 21.1 rem at $200 \mathrm{~m}$ resulting from the inhalation of plutonium and americium particulates.

In general, the isotopes of rubidium including $\mathrm{Rb}-89, \mathrm{Rb}-90$, and $\mathrm{Rb}-91$ provide the greatest overal1 exposure from excursion accident scenarios at distances less than $1 \mathrm{~km}$. Between $1 \mathrm{~km}$ and $4400 \mathrm{~m}$ a mixture of isotopes of rubidium, cesium, krypton, and xenon compete for most significant radionuclide contribution. Beyond $4400 \mathrm{~m}$, the excursion accident scenarios display the tendency towards a decreasing contribution from the air immersion pathway. In fact, in both the GODIVA and XGODIVA analysis, the inhalation pathway becomes the most significant pathway at distances of $4400 \mathrm{~m}$ or greater. This is due to the decay of the fission products and relative longevity of the actinide radionuclides with large inhalation pathway contribution.

The plutonium particulate releases display a consistent maximum contribution from the Pu-239 and Am-24I radionuclides via the inhalation pathway irrespective of receptor distance. This is consistent with the longevity of those contributing radionuclides compared with the decay time. 
Table 4-1

\section{Summary of EDE's Calculated for TA-18 Postulated Accident Scenarios}

\begin{tabular}{|c|c|c|c|c|c|c|c|c|c|}
\hline \multirow{2}{*}{ Scenario } & \multirow{2}{*}{$\begin{array}{r}\begin{array}{r}\text { Receptor } \\
\text { Distance } \\
(\mathrm{m})\end{array} \\
200 \\
1000 \\
4400\end{array}$} & \multicolumn{2}{|c|}{$\begin{array}{l}\text { Wind Speed with } \\
\text { Maximum EDE } \\
(\mathrm{m} / \mathrm{s}) \text { (rem) } \\
\end{array}$} & \multicolumn{2}{|c|}{$\begin{array}{r}\text { Exposure Mode } \\
\text { Contribution }\end{array}$} & \multicolumn{4}{|c|}{$\begin{array}{l}\text { Effective Dose Equivalent } \\
\text { Dose Contribution } \\
\text { Nuclide \% Origination }\end{array}$} \\
\hline & & $\begin{array}{l}1 \\
1 \\
1\end{array}$ & $\begin{array}{l}6.90 \\
0.30 \\
0.033\end{array}$ & Inhalation & $\begin{array}{l}100 \\
100 \\
100\end{array}$ & $\begin{array}{l}U-234 \\
U-234 \\
U-234\end{array}$ & $\begin{array}{l}97 \\
97 \\
97\end{array}$ & $\begin{array}{l}\text { Parent } \\
\text { Parent } \\
\text { Parent }\end{array}$ & \\
\hline \multirow[t]{3}{*}{ WINCO } & 200 & 10 & 5.02 & $\begin{array}{l}\text { Air } \\
\text { Immersion }\end{array}$ & 98 & $\begin{array}{l}R b-90 \\
\text { Cs-140 } \\
R b-91\end{array}$ & $\begin{array}{l}11 \\
10\end{array}$ & $\begin{array}{l}\mathrm{Kr}-90 \\
\mathrm{Br}-90 \\
\mathrm{Xe}-140 \\
\mathrm{Kr}-91 \\
\mathrm{Br}-91\end{array}$ & $\begin{array}{r}D \\
\text { GD } \\
D \\
D \\
\text { GD }\end{array}$ \\
\hline & 1000 & 10 & 0.17 & & 97 & $\begin{array}{l}\mathrm{Rb}-90 \\
\mathrm{Kr}-89 \\
\mathrm{Kr}-93\end{array}$ & $\begin{array}{r}15 \\
9 \\
9\end{array}$ & $\begin{array}{l}\text { Kr }-90 \\
\text { Br-90 } \\
\text { Parent } \\
\text { Br-89 } \\
\text { Parent }\end{array}$ & $\begin{array}{r}\text { D } \\
\text { GD } \\
\text { GD }\end{array}$ \\
\hline & 4400 & 7 & 0.022 & & 89 & $\begin{array}{l}\text { Cs-138 } \\
\text { Rb-89 } \\
X e-138\end{array}$ & $\begin{array}{l}24 \\
15 \\
\\
12\end{array}$ & $\begin{array}{l}\text { Xe-138 } \\
\mathrm{Kr}-89 \\
\text { Br-89 } \\
\text { Parent }\end{array}$ & $\begin{array}{r}D \\
D \\
G D \\
D\end{array}$ \\
\hline \multirow[t]{3}{*}{ SHEBA } & 200 & 10 & 4.31 & $\begin{array}{l}\text { Air } \\
\text { Immersion }\end{array}$ & 99 & $\begin{array}{l}R b-90 \\
C s-140 \\
R b-91\end{array}$ & $\begin{array}{l}16 \\
14 \\
13\end{array}$ & $\begin{array}{l}\mathrm{Kr}-90 \\
\mathrm{Xe}-140 \\
\mathrm{Kr}-91 \\
8 r-91\end{array}$ & $\begin{array}{r}D \\
D \\
D \\
\text { GD }\end{array}$ \\
\hline & 1000 & 10 & 0.13 & & 98 & $\begin{array}{l}\mathrm{Rb}-90 \\
\mathrm{Kr}-89 \\
\mathrm{Cs}-140\end{array}$ & $\begin{array}{l}21 \\
13 \\
11\end{array}$ & $\begin{array}{l}\mathrm{Kr}-90 \\
\text { Br-90 } \\
\text { Parent } \\
\text { Br-89 } \\
\text { Xe-140 }\end{array}$ & $\begin{array}{r}D \\
G D \\
G D \\
D\end{array}$ \\
\hline & 4400 & 10 & 0.0068 & & 93 & $\begin{array}{l}R b-89 \\
X e-138 \\
\text { Cs-138 }\end{array}$ & $\begin{array}{l}19 \\
17 \\
14\end{array}$ & $\begin{array}{l}\mathrm{Kr}-89 \\
\text { Br-89 } \\
\text { Parent } \\
\text { Xe-138 }\end{array}$ & $\begin{array}{r}0 \\
60 \\
0\end{array}$ \\
\hline \multirow[t]{3}{*}{ FLATTOP } & 200 & 10 & 13.0 & Inhalation & 100 & $\begin{array}{l}P u-239 \\
\mathrm{Am}-241 \\
\mathrm{Pu}-240\end{array}$ & $\begin{array}{l}61 \\
20 \\
14\end{array}$ & $\begin{array}{l}\text { Parent } \\
\text { Parent } \\
\text { Parent }\end{array}$ & \\
\hline & 1000 & 7 & 0.64 & & 100 & $\begin{array}{l}P u-239 \\
\text { Am-241 } \\
P u-240\end{array}$ & $\begin{array}{l}60 \\
20 \\
14\end{array}$ & $\begin{array}{l}\text { Parent } \\
\text { Parent } \\
\text { Parent }\end{array}$ & \\
\hline & 4400 & 7 & 0.28 & & 100 & $\begin{array}{l}P u-239 \\
\text { Am-241 } \\
\text { Pu-240 }\end{array}$ & $\begin{array}{l}60 \\
20 \\
14\end{array}$ & $\begin{array}{l}\text { Parent } \\
\text { Parent } \\
\text { Parent }\end{array}$ & \\
\hline
\end{tabular}

2 - Origination is either the initial parent, daughter(D) or granddaughter(GD) 


\begin{tabular}{|c|c|c|c|c|c|c|c|c|c|}
\hline \multirow{3}{*}{$\begin{array}{l}\text { Scenario } \\
\text { GODIVA } \\
-\end{array}$} & \multirow{3}{*}{$\begin{array}{r}\begin{array}{r}\text { Receptor } \\
\text { Distance } \\
\text { (m) }\end{array} \\
200\end{array}$} & \multirow{2}{*}{\multicolumn{2}{|c|}{$\begin{array}{l}\text { Wind Speed with } \\
\text { Maximum EDE } \\
\text { (m/s) (rem) }\end{array}$}} & \multicolumn{2}{|c|}{$\begin{array}{l}\text { Exposure Hode } \\
\text { Contribution }\end{array}$} & \multirow{2}{*}{\multicolumn{4}{|c|}{$\begin{array}{l}\text { Effective Dose Equivalent } \\
\text { Dose Contribution } \\
\text { Nuclide } \% \text { Origination }\end{array}$}} \\
\hline & & & & Pathway & $\%$ & & & & \\
\hline & & 10 & 0.77 & $\begin{array}{l}\text { Air } \\
\text { Immers ion }\end{array}$ & 90 & $R b-90$ & 12 & $\begin{array}{l}\mathrm{Kr}-90 \\
8 \mathrm{r}-90\end{array}$ & $\begin{array}{r}D \\
G D\end{array}$ \\
\hline & & & & & & $\begin{array}{l}\mathrm{Cs}_{s}-140 \\
\mathrm{Kr}-89\end{array}$ & $\begin{array}{l}9 \\
8\end{array}$ & $\begin{array}{l}\text { Xe-140 } \\
\text { Parent } \\
\text { Br-89 }\end{array}$ & $\begin{array}{l}D \\
0\end{array}$ \\
\hline & 1000 & 10 & 0.28 & & 86 & $\begin{array}{l}R b-90 \\
R b-89 \\
X e-138\end{array}$ & $\begin{array}{r}12 \\
10 \\
7\end{array}$ & $\begin{array}{l}\mathrm{Kr}-90 \\
\mathrm{Br}-90 \\
\mathrm{Kr}-89 \\
\mathrm{Br}-89 \\
\text { Parent }\end{array}$ & $\begin{array}{r}D \\
60 \\
D \\
6 D\end{array}$ \\
\hline & 4400 & 7 & 0.0054 & Inhalation & 53 & $\begin{array}{l}U-234 \\
R b-89 \\
X e-138\end{array}$ & $\begin{array}{l}39 \\
10 \\
7\end{array}$ & $\begin{array}{l}\text { Parent } \\
\text { Kr-89 } \\
\text { Br-89 } \\
\text { Parent }\end{array}$ & GD \\
\hline \multirow[t]{3}{*}{ XGODIVA } & 200 & 1 & 43.5 & $\begin{array}{l}\text { Air } \\
\text { Immersion }\end{array}$ & 94 & $\begin{array}{l}\mathrm{Rb}-90 \\
\mathrm{Kr}-89 \\
\mathrm{Cs}-140\end{array}$ & $\begin{array}{l}21 \\
14 \\
11\end{array}$ & $\begin{array}{l}\mathrm{Kr}-90 \\
\text { Br-90 } \\
\text { Parent } \\
\text { Xe-140 }\end{array}$ & $\begin{array}{r}\text { DD } \\
0\end{array}$ \\
\hline & 1000 & 4 & 0.68 & & 90 & $\begin{array}{l}R b-90 \\
K r-89 \\
R b-89\end{array}$ & $\begin{array}{r}18 \\
12 \\
7\end{array}$ & $\begin{array}{l}\mathrm{Kr}-90 \\
\mathrm{Br}-90 \\
\text { Parent } \\
\mathrm{Br}-89 \\
\mathrm{Kr}-89 \\
\mathrm{Br}-89\end{array}$ & $\begin{array}{r}D \\
G D \\
\\
D \\
D \\
G D\end{array}$ \\
\hline & 4400 & 1 & 0.032 & Inhalation & 67 & $\begin{array}{l}\mathrm{U}-234 \\
\mathrm{Rb}-89 \\
\mathrm{Xe}-138\end{array}$ & $\begin{array}{r}50 \\
9 \\
8\end{array}$ & $\begin{array}{l}\text { Parent } \\
\text { Kr-89 } \\
\text { Br-89 } \\
\text { Parent }\end{array}$ & GD \\
\hline \multirow[t]{3}{*}{ SKUA } & 200 & 7 & 21.1 & Inhalation & 100 & $\begin{array}{l}P u-239 \\
A m-241 \\
P u-240\end{array}$ & $\begin{array}{l}61 \\
20 \\
14\end{array}$ & $\begin{array}{l}\text { Parent } \\
\text { Parent } \\
\text { Parent }\end{array}$ & \\
\hline & 1000 & 7 & 1.03 & & & $\begin{array}{l}P_{u}-239 \\
A_{m}-241 \\
P_{u}-240\end{array}$ & $\begin{array}{l}60 \\
20 \\
14\end{array}$ & $\begin{array}{l}\text { Parent } \\
\text { Parent } \\
\text { Parent }\end{array}$ & \\
\hline & 4400 & 6 & 0.40 & & & $\begin{array}{l}P_{u}-239 \\
A m-241 \\
P_{u}-240\end{array}$ & $\begin{array}{l}60 \\
20 \\
14\end{array}$ & $\begin{array}{l}\text { Parent } \\
\text { Parent } \\
\text { Parent }\end{array}$ & \\
\hline \multirow[t]{3}{*}{ Vault } & 200 & 10 & 5.03 & Inhalation & 100 & $\begin{array}{l}P u-239 \\
A m-241 \\
P u-240\end{array}$ & $\begin{array}{l}61 \\
20 \\
14\end{array}$ & $\begin{array}{l}\text { Parent } \\
\text { Parent } \\
\text { Parent }\end{array}$ & \\
\hline & 1000 & 9 & 0.24 & & & $\begin{array}{l}P u-239 \\
A m-241 \\
P u-240\end{array}$ & $\begin{array}{l}61 \\
20 \\
14\end{array}$ & $\begin{array}{l}\text { Parent } \\
\text { Parent } \\
\text { Parent }\end{array}$ & \\
\hline & 4400 & 8 & 0.12 & & & $\begin{array}{l}P u-239 \\
A n-241 \\
P u-240\end{array}$ & $\begin{array}{l}60 \\
20 \\
14\end{array}$ & $\begin{array}{l}\text { Parent } \\
\text { Parent } \\
\text { Parent }\end{array}$ & \\
\hline
\end{tabular}




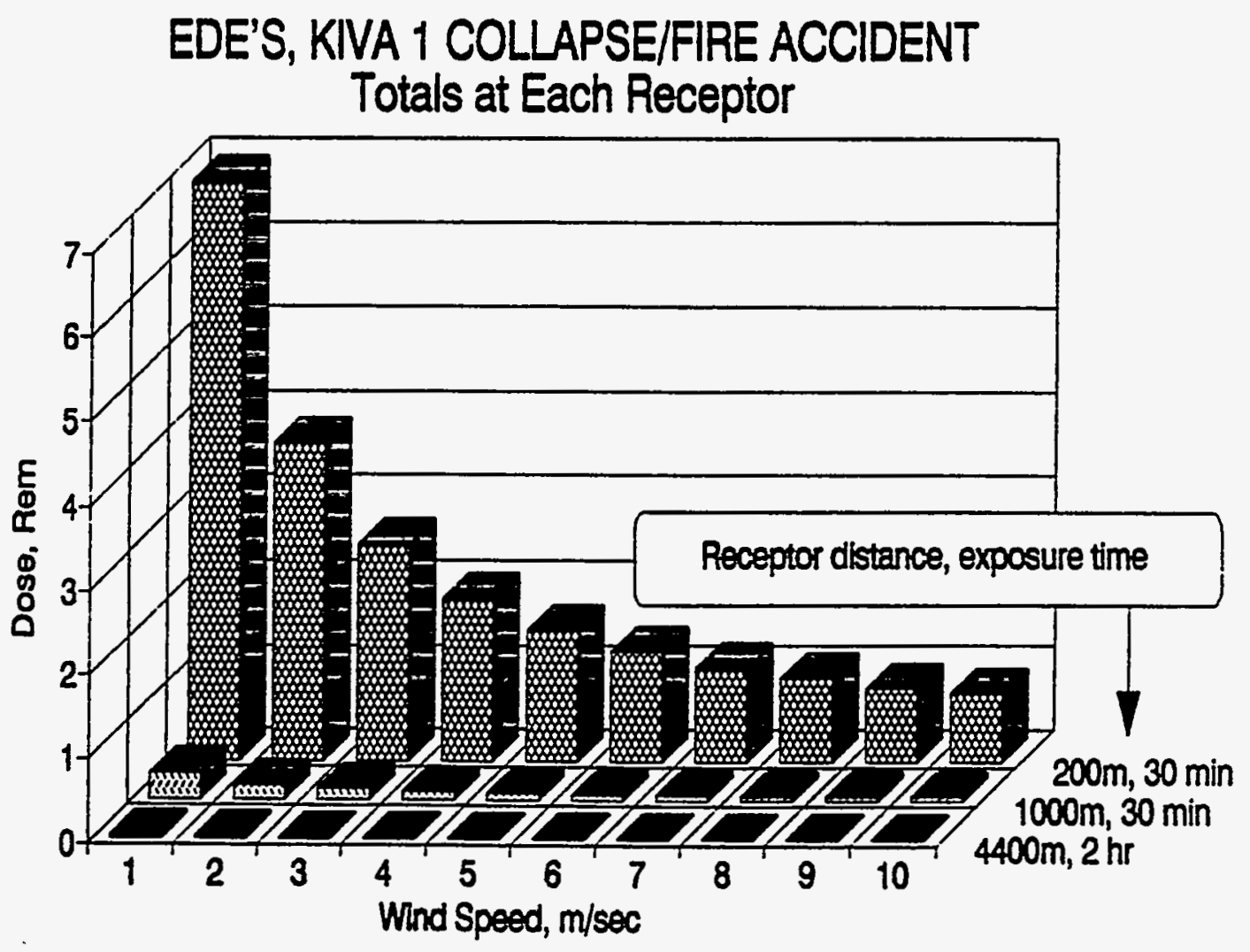




\section{EDE'S, KIVA 1 COLLAPSE/FIRE ACCIDENT Pathway Contribution}

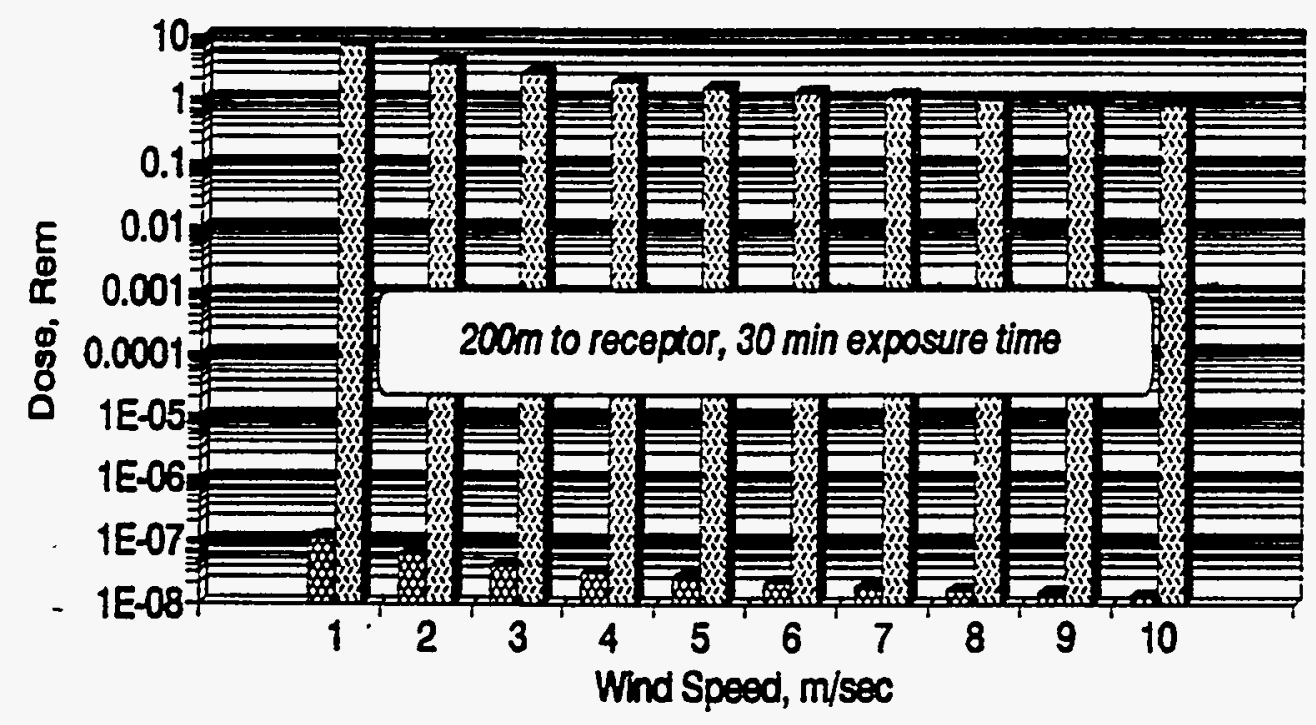

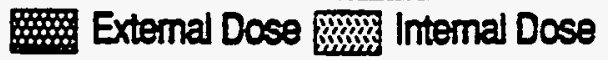

Figure 4-2: Pathway Contribution EDE's - Kiva 1 Collapse/Fire 


\section{EDE'S, SHEBA EXCURSION ACCIDENT}

Totals at Each Receptor

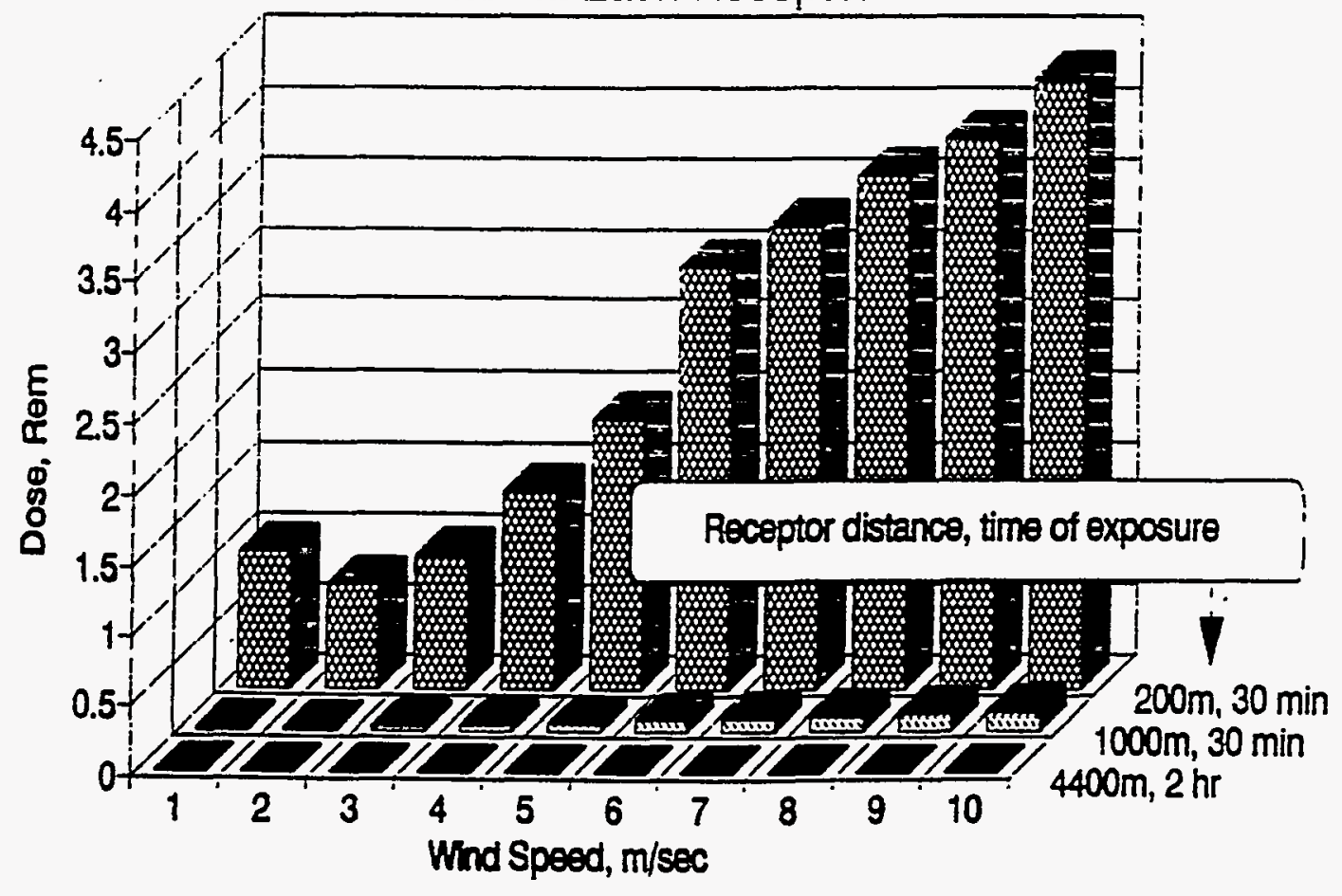

Figure 4-3: Receptor Total EDE's - SHEBA Excursion Accident 


\section{EDE'S, SHEBA EXCURSION ACCIDENT \\ Pathway Contribution}

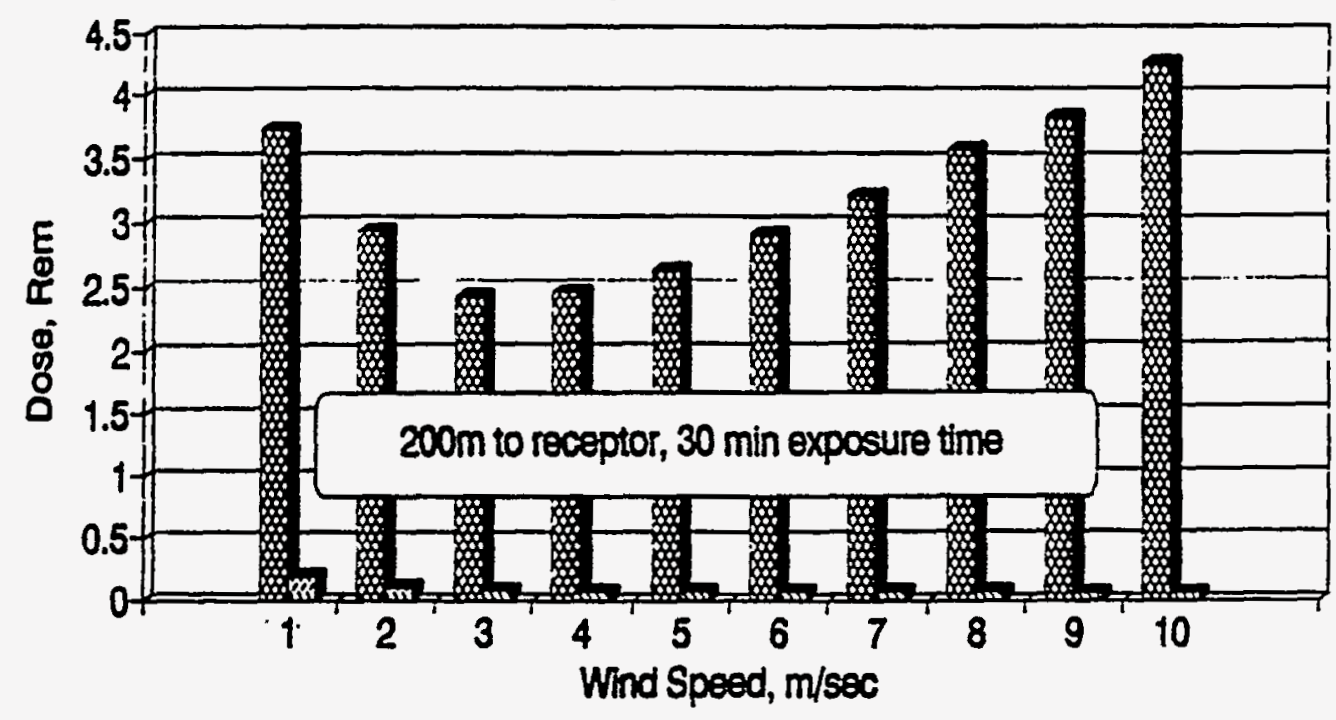

Extemal Dose intemal Dose

Figure 4-4: Pathway Contribution EDE's - SHEBA Excursion Accident 


\section{EDE'S, HILSIDE VAULT COLLAPSE ACCIDENT Totals at Each Receptor}

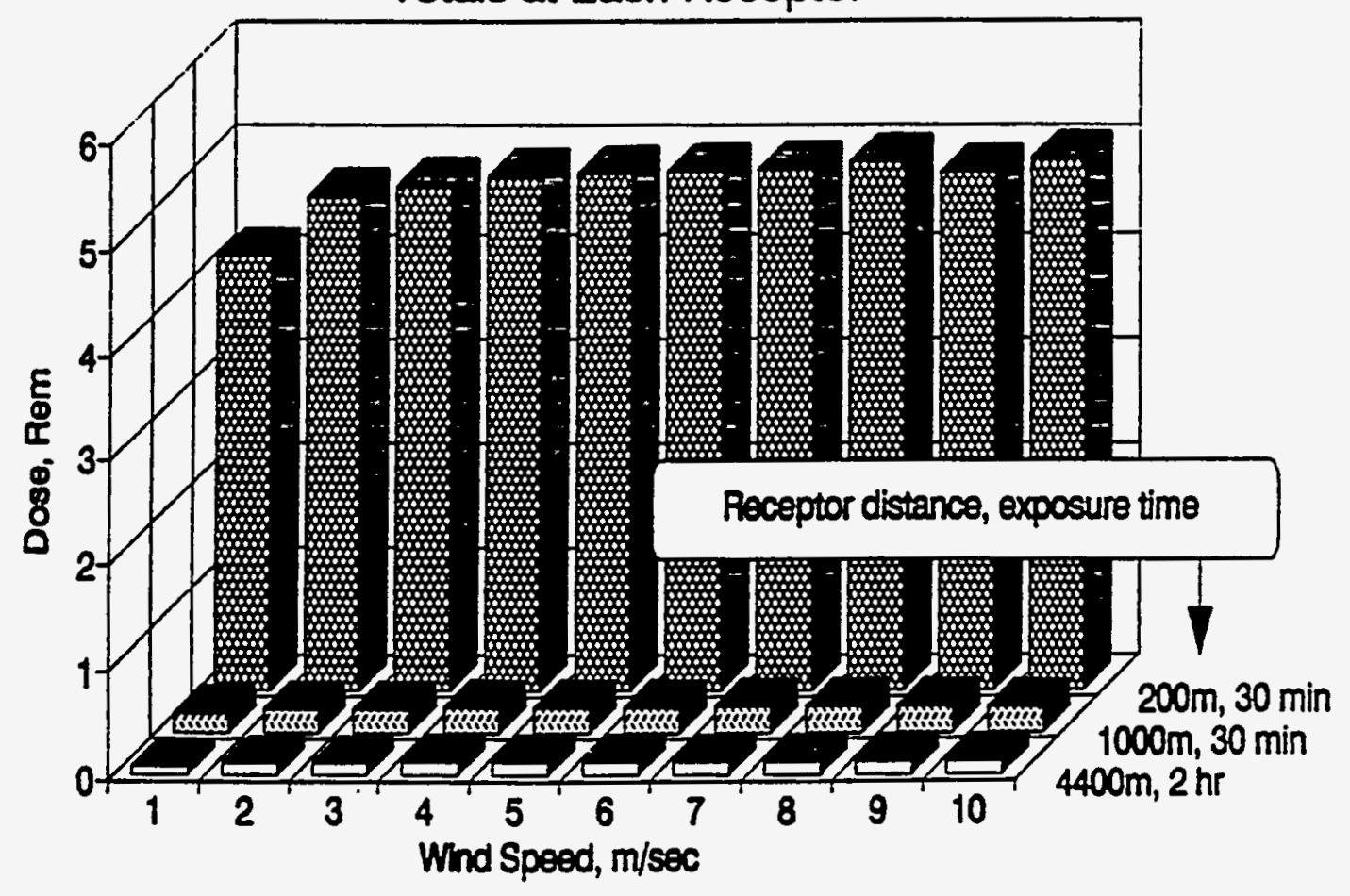

Figure 4-5: Receptor Total EDE's - Hillside Vault Collapse Accident 


\section{EDE'S, HILLSIDE VAULT COLLAPSE ACCIDENT Pathway Contribution}

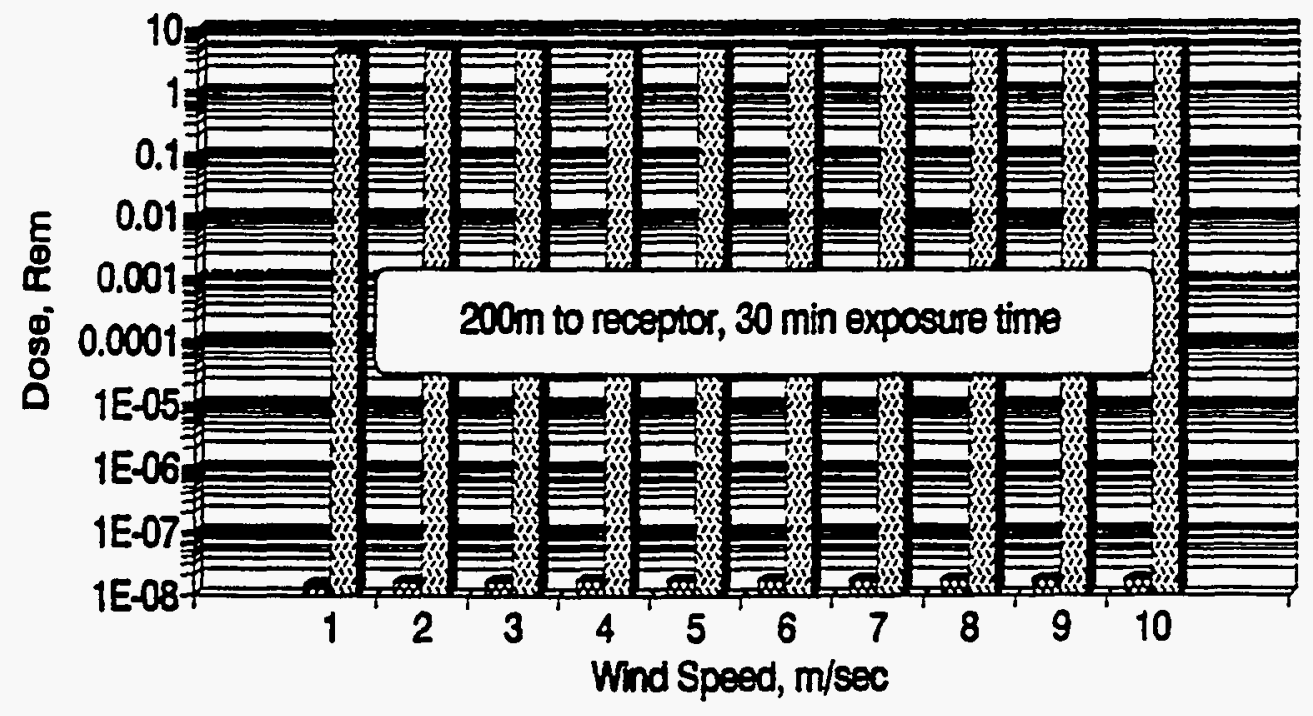

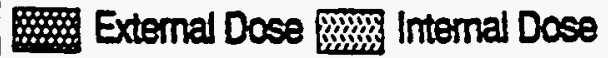

Figure 4-6: Pathway Contribution EDE's - Hillside Vault Collapse Accident 


\section{EDE'S, WINCO BREECH/EXCURSION ACCIDENT}

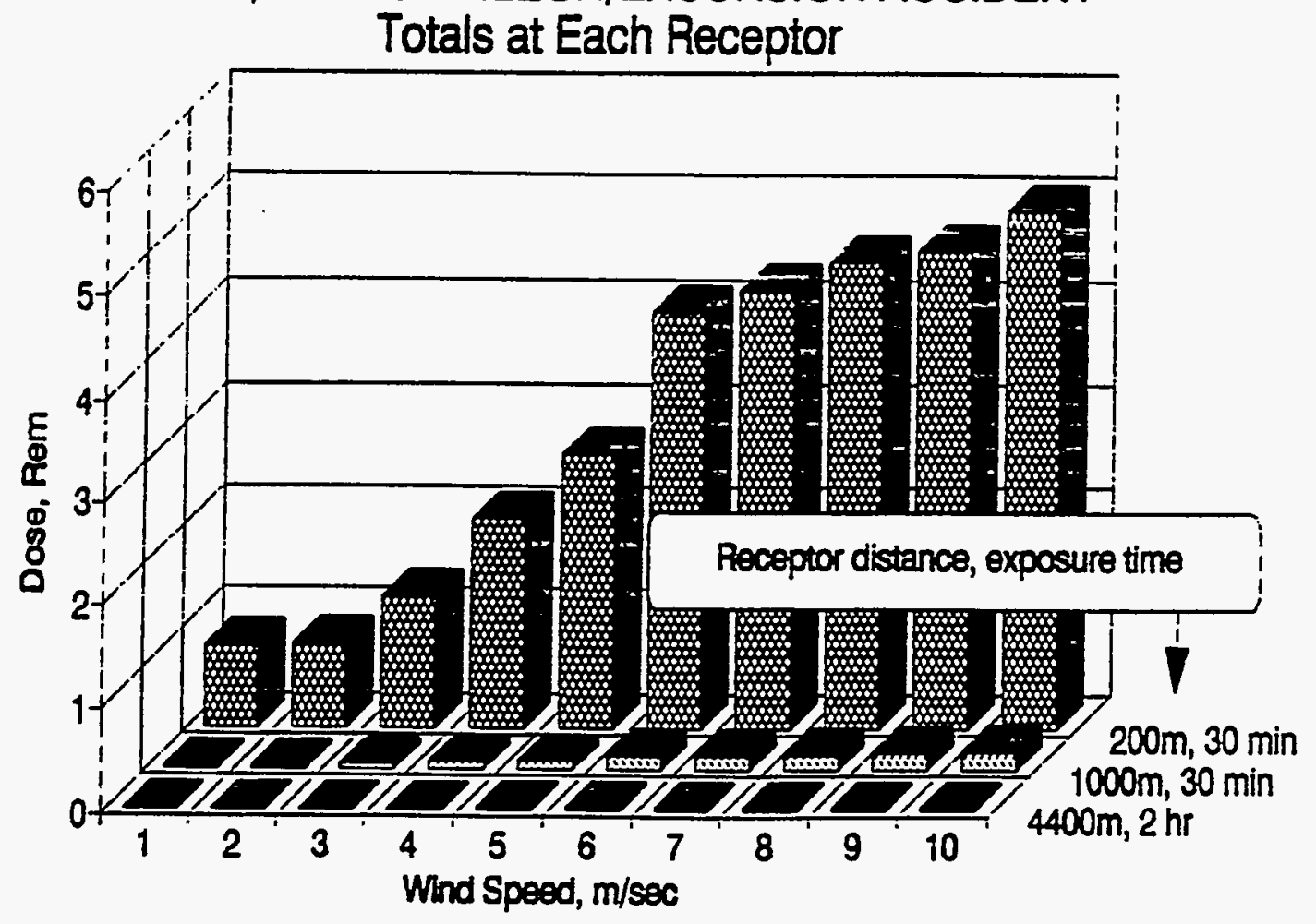

Figure 4-7: Receptor Total EDE's - WINCO Breech/Excursion Accident 


\section{EDE'S, WINCO BREECH/EXCURSION ACCIDENT Pathway Contribution}

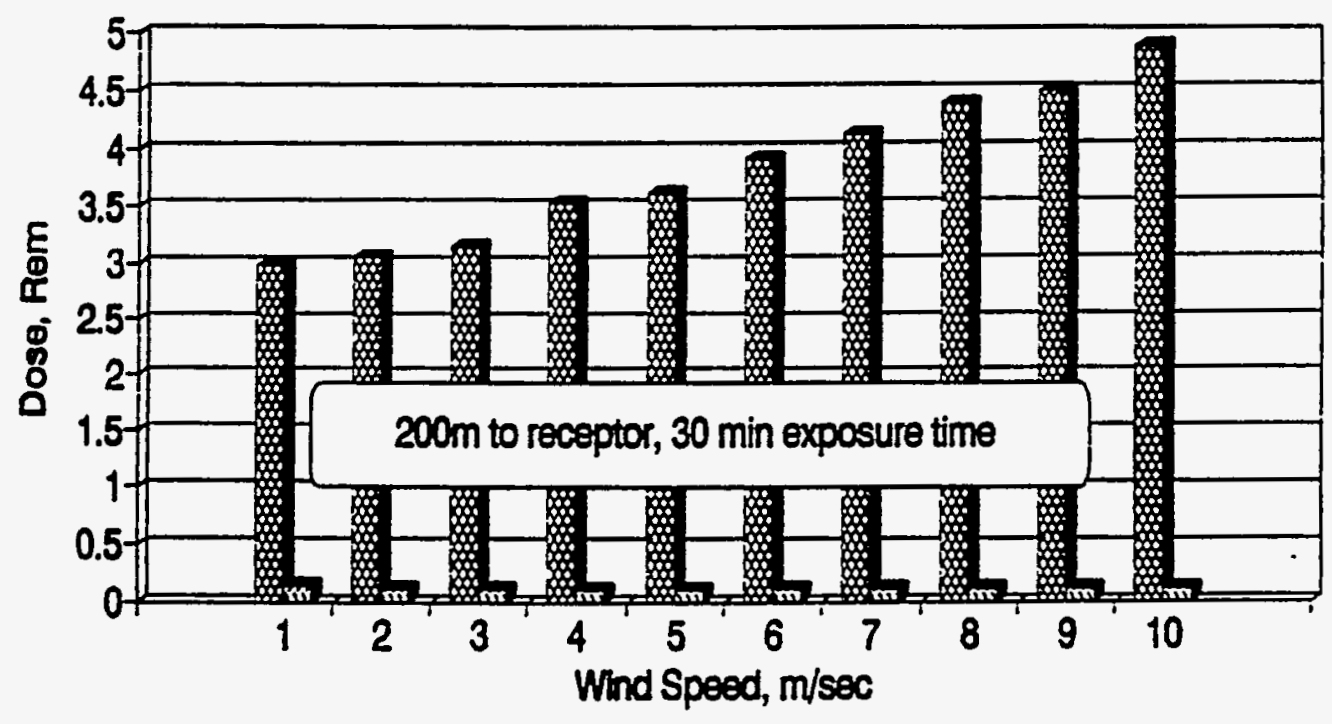

Extemal Dose intemal Dose

Figure 4-8: Pathway Contribution EDE's - WINCO Breech/Excursion Accident 


\section{EDE'S, GODIVA EXTERNAL OPN ACCIDENT Totals at Each Receptor}

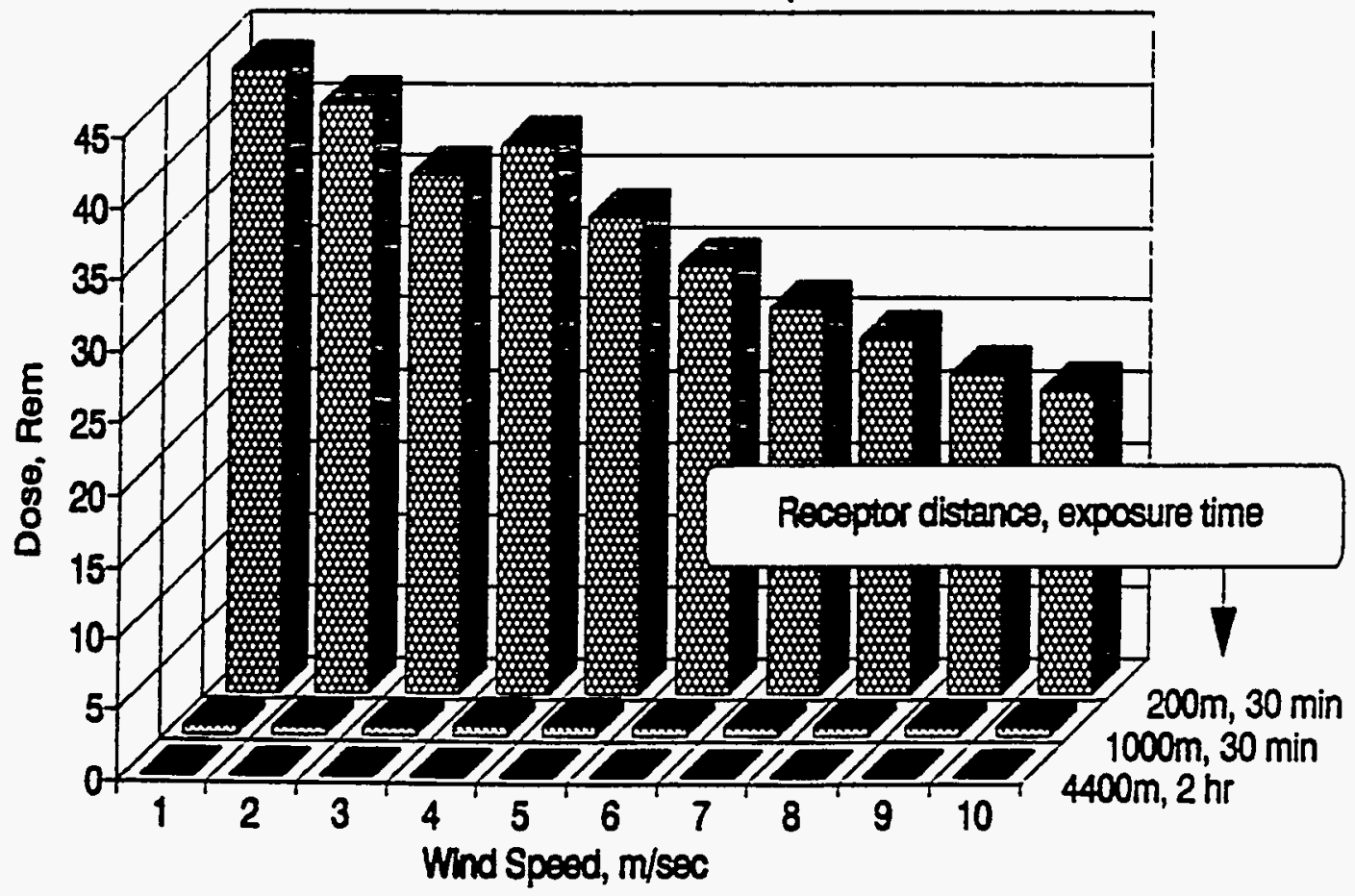

Figure 4-9: Receptor Total EDE's - GODIVA External Operation Accident 


\section{EDE'S, GODIVA EXTERNAL OPN ACCIDENT Pathway Contribution}

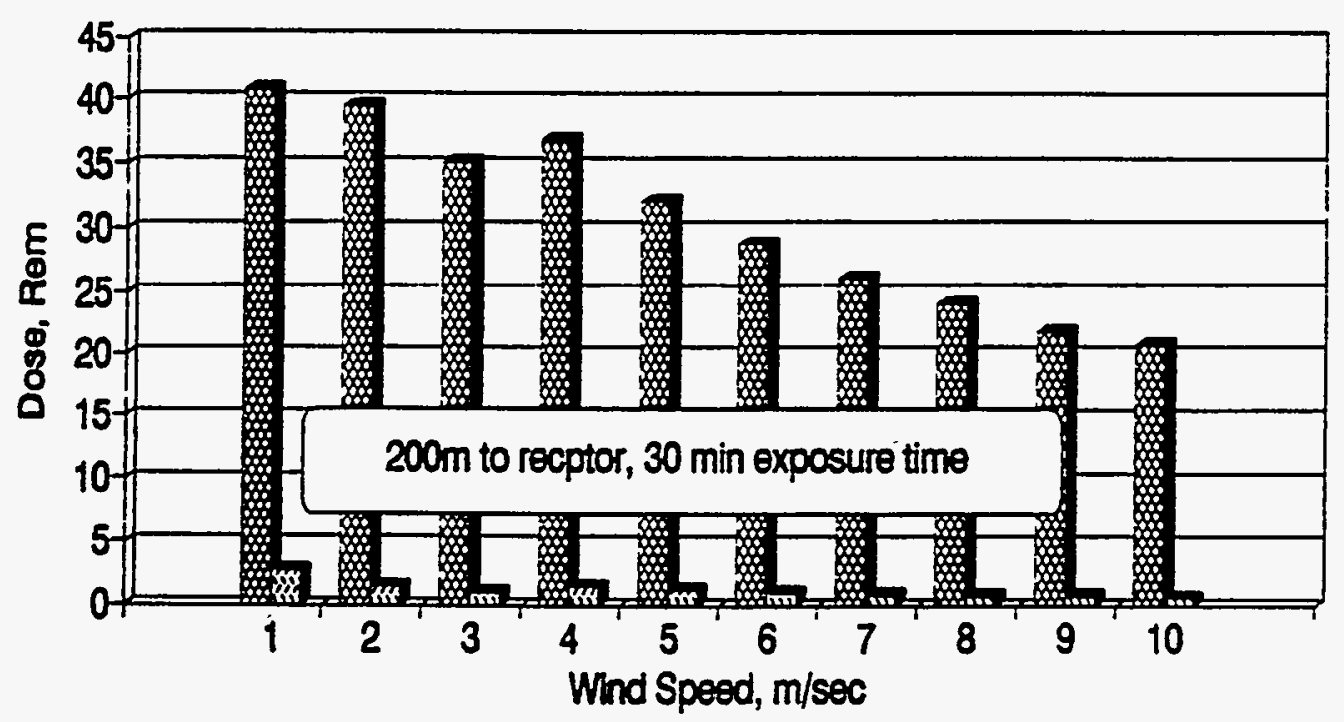

External Dose in intemal Dose

Figure 4-10: Pathway Contribution EDE's - GODIVA External Operation Accident 


\section{EDE'S, FLATTOP PU EXCURSION ACCIDENT Totals at Each Receptor}

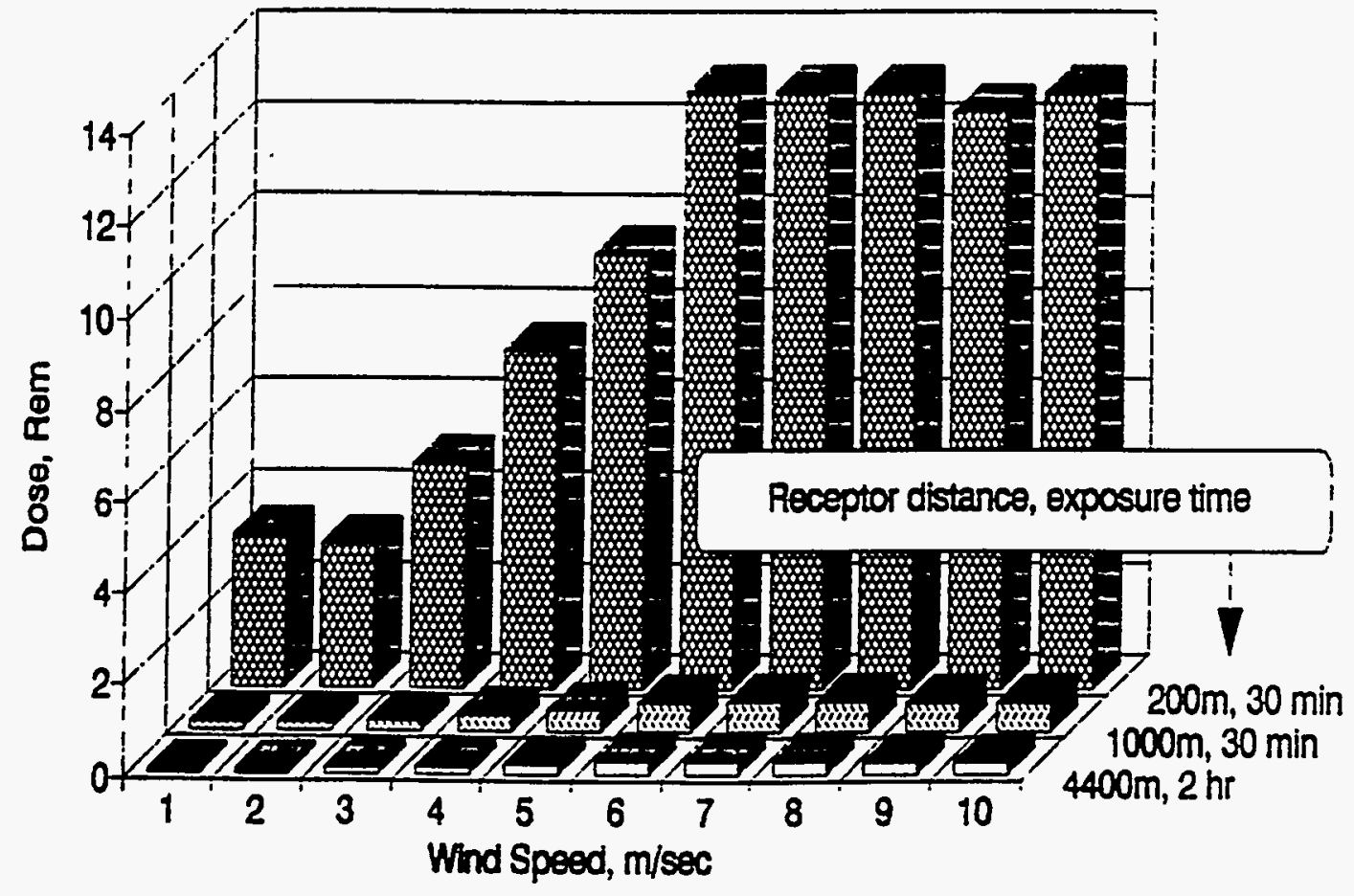

Figure 4-11: Receptor Total EDE's - FLATTOP Pu Excursion Accident 


\section{EDE'S, FLATTOP PU EXCURSION ACCIDENT Pathway Contribution}

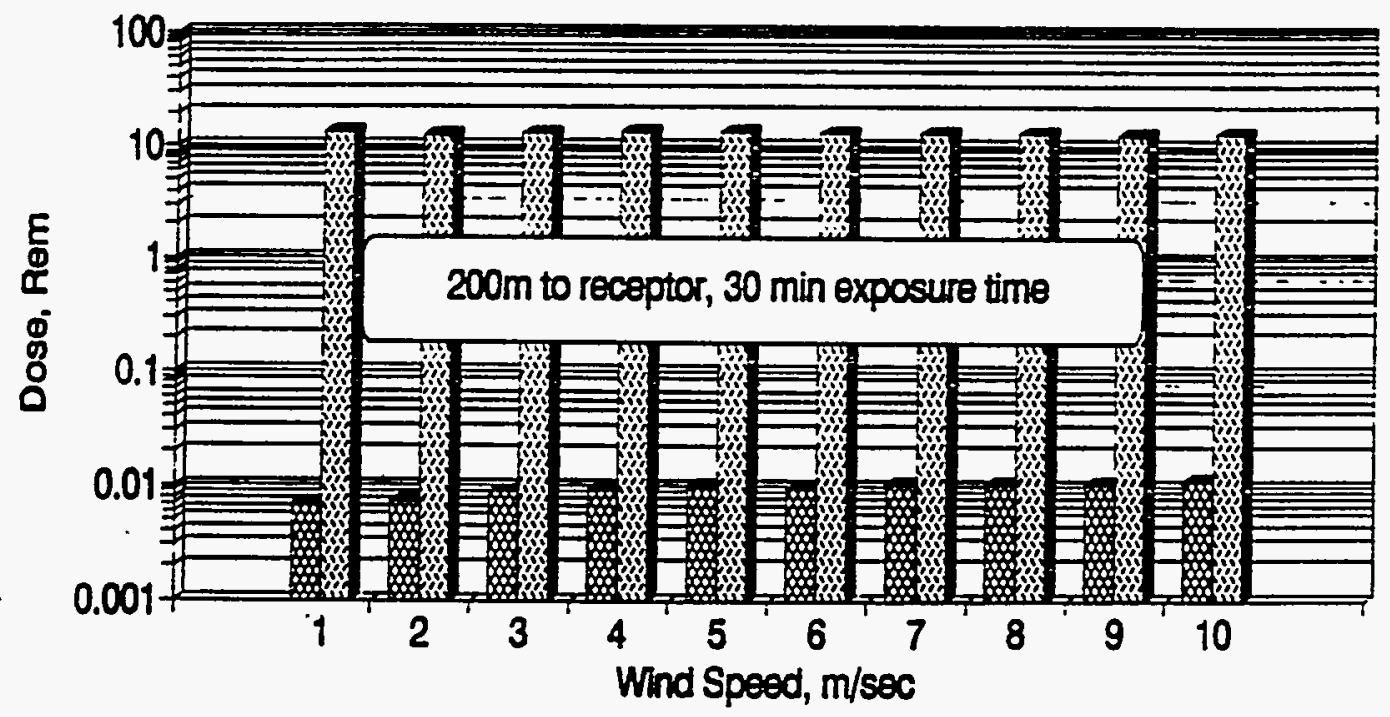

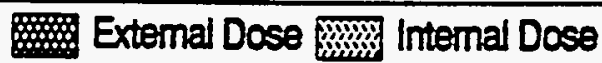

Figure 4-12: Pathway Contribution EDE's - FLATTOP Pu Excursion Accident 


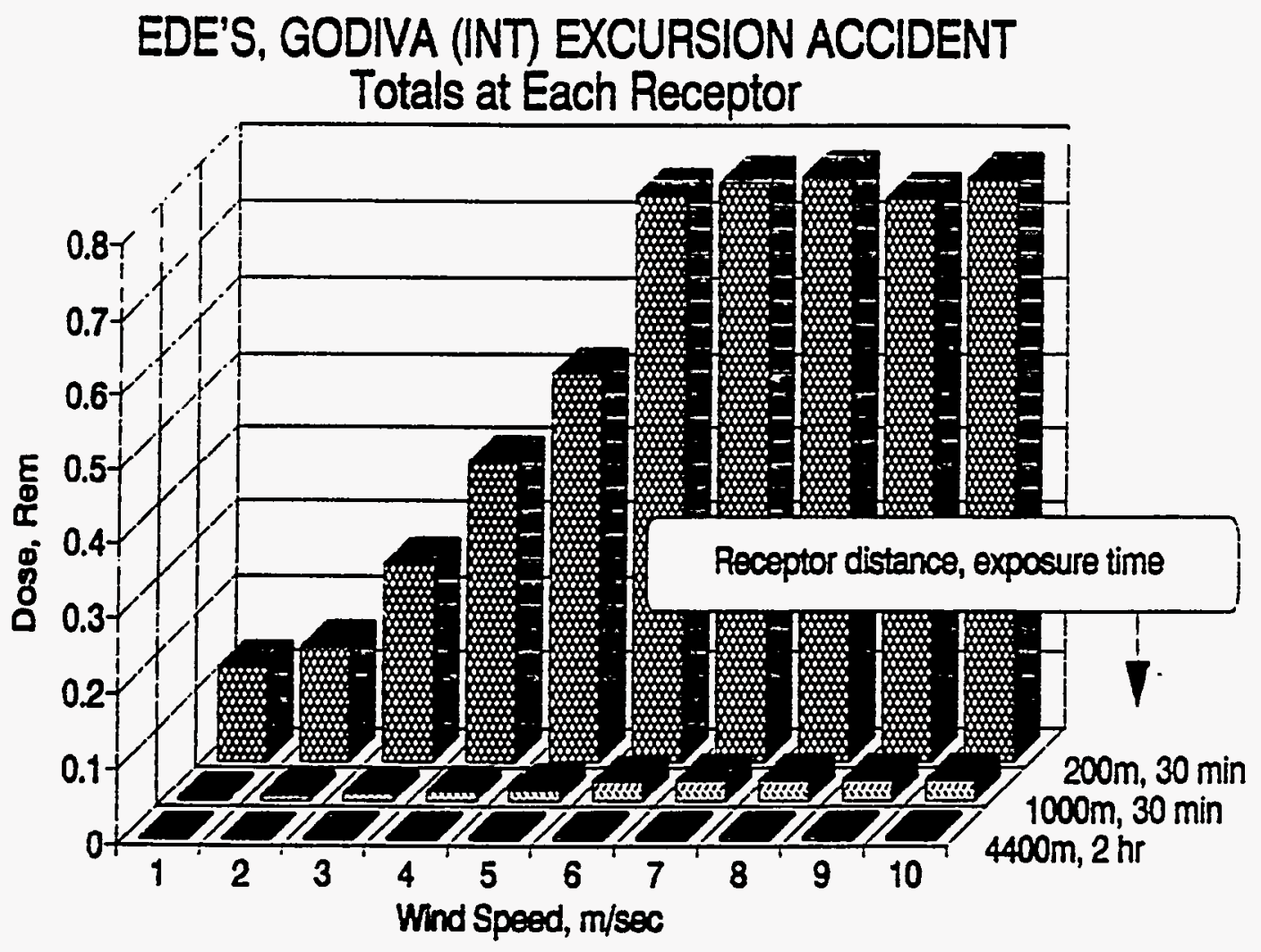

Figure 4-13: Receptor Total EDE's - GODIVA Kiva 3 Excursion Accident 


\section{EDE'S, GODIVA (INT) EXCURSION ACCIDENT Pathway Contribution}

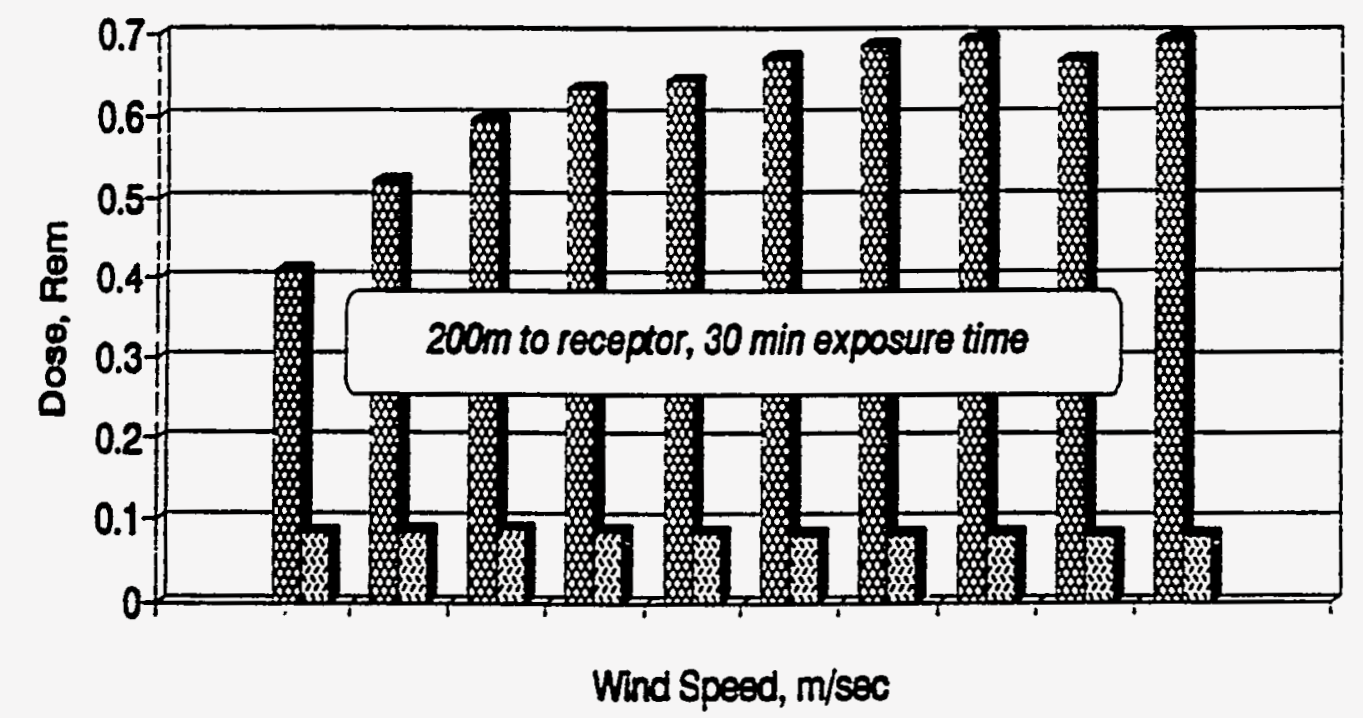

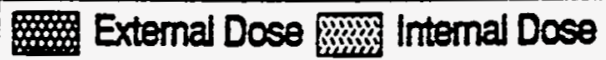

Figure 4-14: Pathway Contribution EDE's - GODIVA Kiva 3 Excursion Accident 


\section{EDE'S, SKUA PU VAPORIZATION ACCIDENT Totals at Each Receptor}

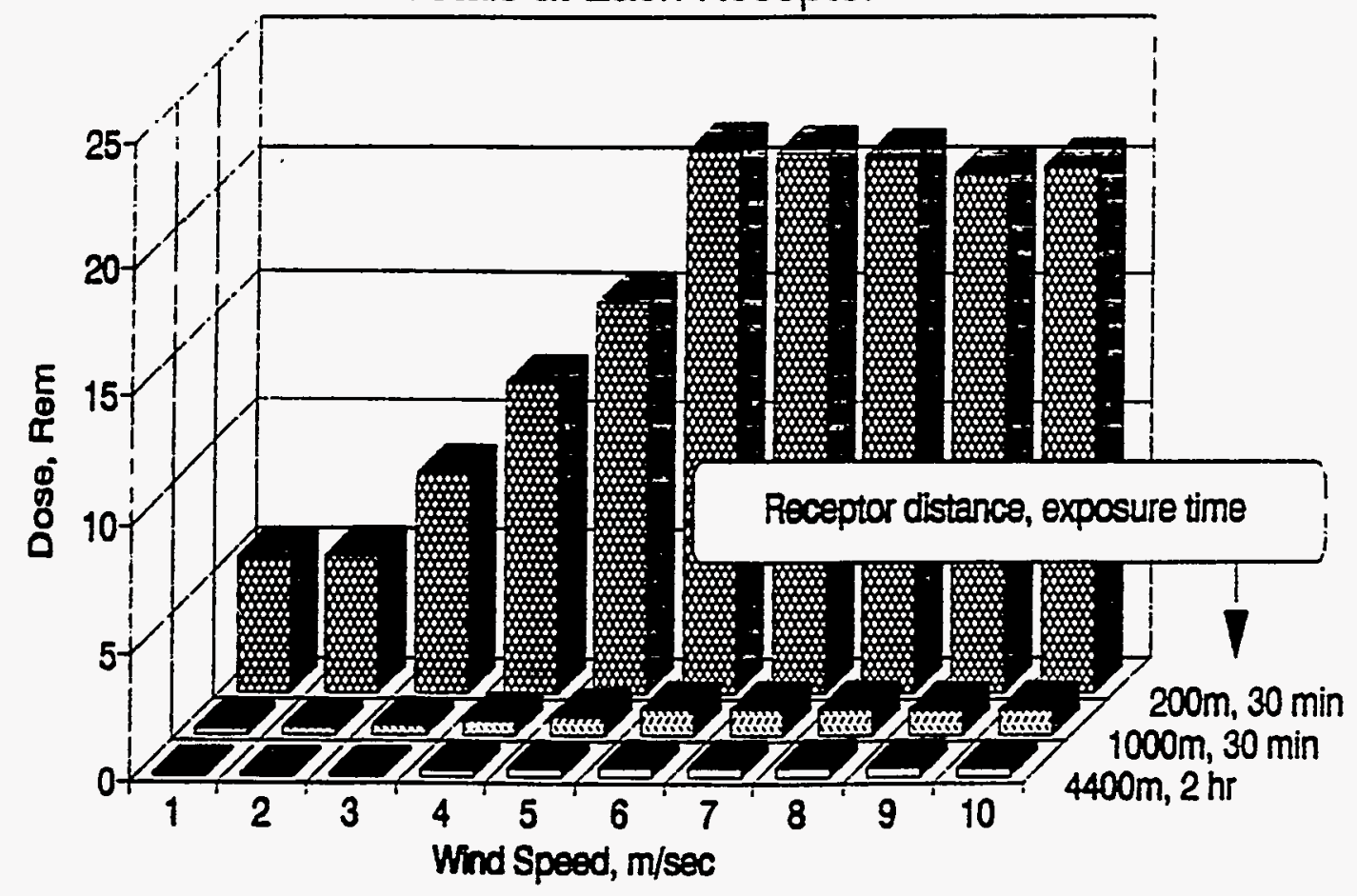

Figure 4-15: Receptor Total EDE's - SKUA Pu Vaporization Accident 


\section{EDE'S, SKUA PU VAPORIZATION ACCIDENT Pathway Contribution}

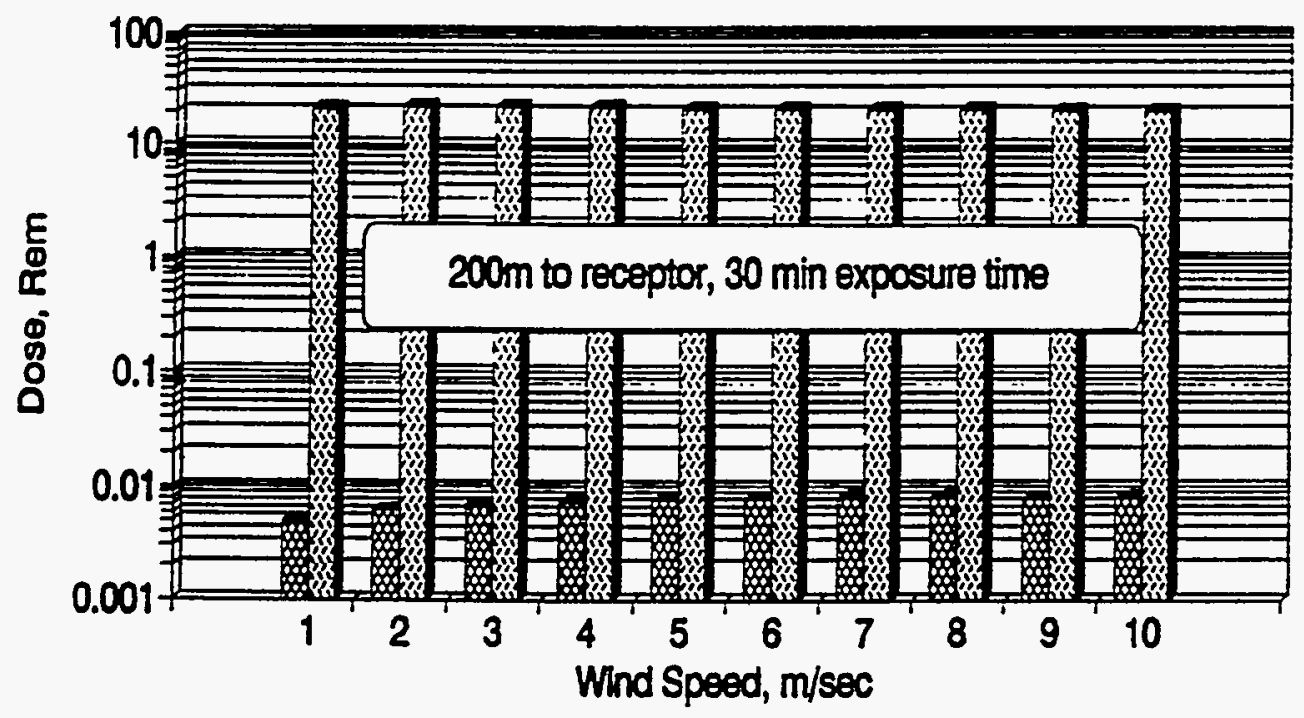

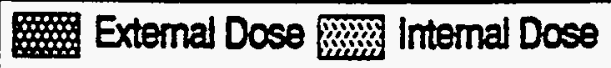

Figure 4-16: Pathway Contribution EDE's - SKUA Pu Vaporization Accident 


\subsection{HAND CALCULATION OF THE ACTIVITY AND DOSE CONTRIBUTION OF THE SELENIUM-89 DECAY SCHEME}

A hand calculation was performed to validate, in part, the method in which the CRIT8 code calculates multiple generation daughter products. The somewhat tedious calculation is supplied in detail as Appendix $B$ at the end of this document. The calculation tracks the Se-89 decay scheme of the XGODIVA accident scenario from initial parent (Se-89) to daughter $(\mathrm{Br}-89)$ to granddaughter $(\mathrm{Kr}-89)$ and final7y to greatgranddaughter $(R b-89)$. This particular decay scheme was used for several reasons

1) The decay is a significant contributor to the resulting dose.

2) The decay scheme has non-zero initial daughters (i.e., $\mathrm{Br}-89$ and $\mathrm{Kr}-89$ ) and therefore represents sufficiently complex parent decay and daughter ingrowth of the same radionuclide.

3) The decay tests the bimodal decay strategy and associated path fractions for the decay of $\mathrm{Br}-90$ to $\mathrm{Kr}-89$ and $\mathrm{Kr}-88$.

Results from the hand calculation show only insignificant differences from values calculated using the CRIT8 code. The differences are attributed to the third digit rounding performed throughout the hand calculation. Floating point calculations performed in the computer use six digits. The results of the hand calculation are reproduced in Appendix B. 
APPENDIX A

DATA TABLES USED IN THE CRIT8 MODELING PROCESS 


\section{Table A-1}

Exfiltration Release Fractions for the Kiva 1 Facility

Begin End

Packet Time Time Hind Speed $(\mathrm{m} / \mathrm{s})$

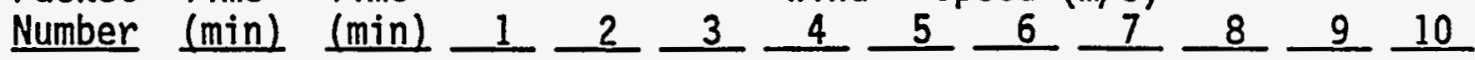

$\begin{array}{lllllllllllll}1 & 0.0 & 1.0 & .002 & .003 & .004 & .006 & .007 & .009 & .011 & .013 & .015 & .018\end{array}$

$\begin{array}{lllllllllllllllll}1 & 1.0 & 2.0 & .002 & .003 & .004 & .006 & .007 & .009 & .011 & .013 & .015 & .018\end{array}$

$\begin{array}{llllllllllllllll}3 & 2.0 & 4.0 & .004 & .006 & .008 & .011 & .014 & .018 & .021 & .025 & .030 & .034\end{array}$

$\begin{array}{llllllllllllllll}4 & 4.0 & 6.0 & .004 & .006 .008 & .011 & .014 & .017 & .021 & .025 & .029 & .033\end{array}$

$\begin{array}{llllllllllllll}5 & 6.0 & 12.0 & .011 & .018 & .025 & .032 & .041 & .050 & .060 & .070 & .081 & .092\end{array}$

$\begin{array}{llllllllllll}6 & 12.0 & 20.0 & .015 & .023 & .032 & .042 & .052 .063 & .074 & .086 & .097 & .088\end{array}$

$\begin{array}{lllllllllllllll}7 & 20.0 & 30.0 & .018 & .028 & .038 & .049 & .061 & .073 & .084 & .095 & .106 & .115\end{array}$

$\begin{array}{lllllllllllll}8 & 30.0 & 45.0 & .027 & .040 & .055 & .069 & .083 & .097 & .110 & .121 & .130 & .138\end{array}$

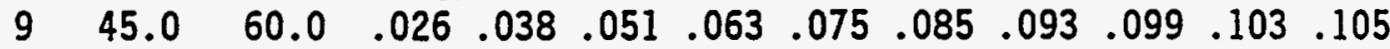

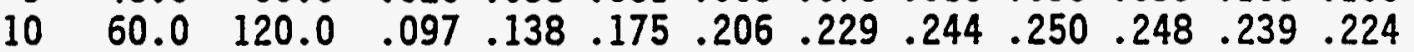

Table A-2

Exfiltration Release Fractions for the Kiva 2 Facility

Begin End

Packet Time Time

Number $\frac{(\min )}{1} \frac{(\min )}{1.0} \frac{1}{.001} \frac{2}{.001} \frac{3}{.002} \frac{4}{.002} \frac{5}{.003} \frac{6}{.003} \frac{7}{.004} \frac{8}{.005} \frac{9}{.005} \frac{10}{.006}$

$\begin{array}{llllllllllllllll}2 & 1.0 & 2.0 & .001 & .001 & .002 & .002 & .003 & .003 & .004 & .004 & .005 & .006\end{array}$

$\begin{array}{llllllllllllllll}3 & 2.0 & 4.0 & .001 & .002 & .003 & .005 & .006 .007 & .008 & .009 & .010 & .011\end{array}$

$\begin{array}{lllllllllllll}4 & 4.0 & 6.0 & .001 & .002 & .003 & .005 & .006 & .007 & .008 & .009 & .010 & .011\end{array}$

$\begin{array}{llllllllllllll}5 & 6.0 & 12.0 & .004 & .007 & .010 & .013 & .017 & .020 & .023 & .026 & .029 & .032\end{array}$

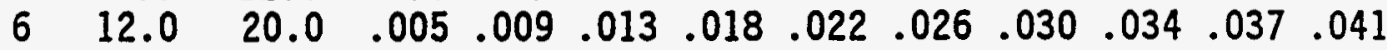

$\begin{array}{lllllllllllllll}7 & 20.0 & 30.0 & .006 & .011 & .016 & .022 & .026 & .031 & .036 & .040 & .045 & .049\end{array}$

$\begin{array}{llllllllllllll}8 & 30.0 & 45.0 & .009 .017 & .024 & .031 .038 .045 & .051 & .057 & .063 & .069\end{array}$

$\begin{array}{lllllllllllllllll}9 & 45.0 & 60.0 & .009 & .016 & .024 & .030 & .037 & .043 & .048 & .053 & .058 & .063\end{array}$

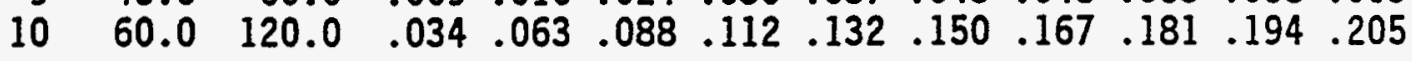


Table A-3

Exfiltration Release Fractions for the Kiva 3 Facility

Begin End

Packet Time Time

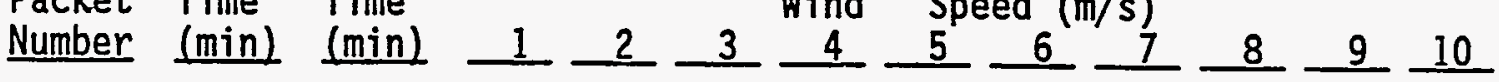

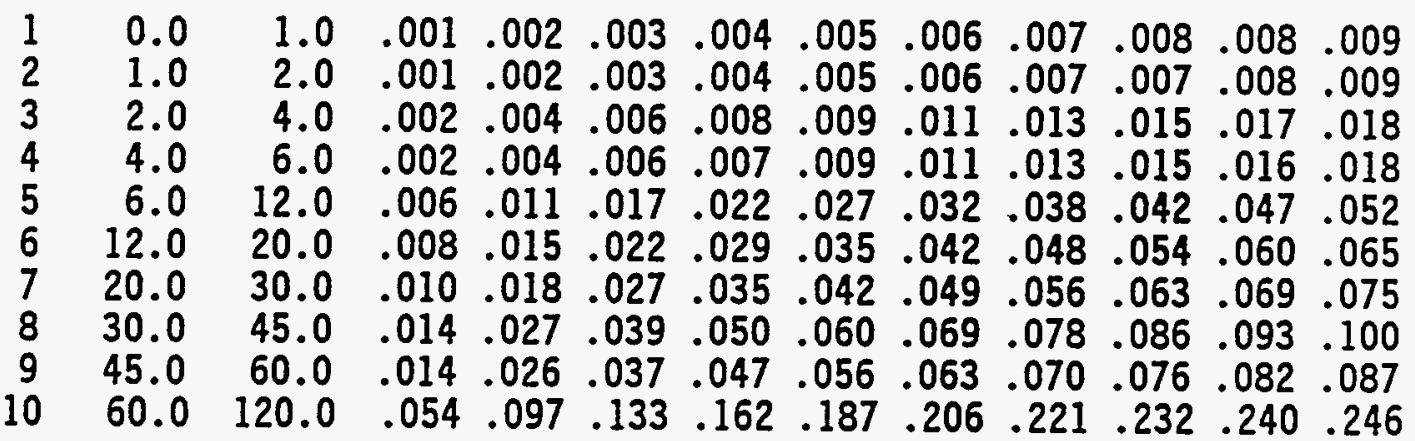

Table A-4

Exfiltration Release Fractions for the Sheba Facility

Begin End

Packet Time Time Hind Speed $(\mathrm{m} / \mathrm{s})$

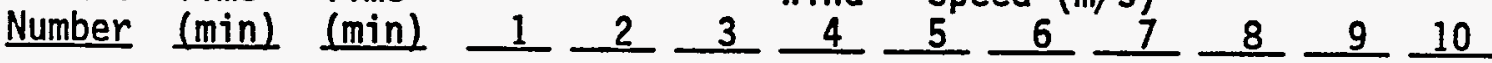

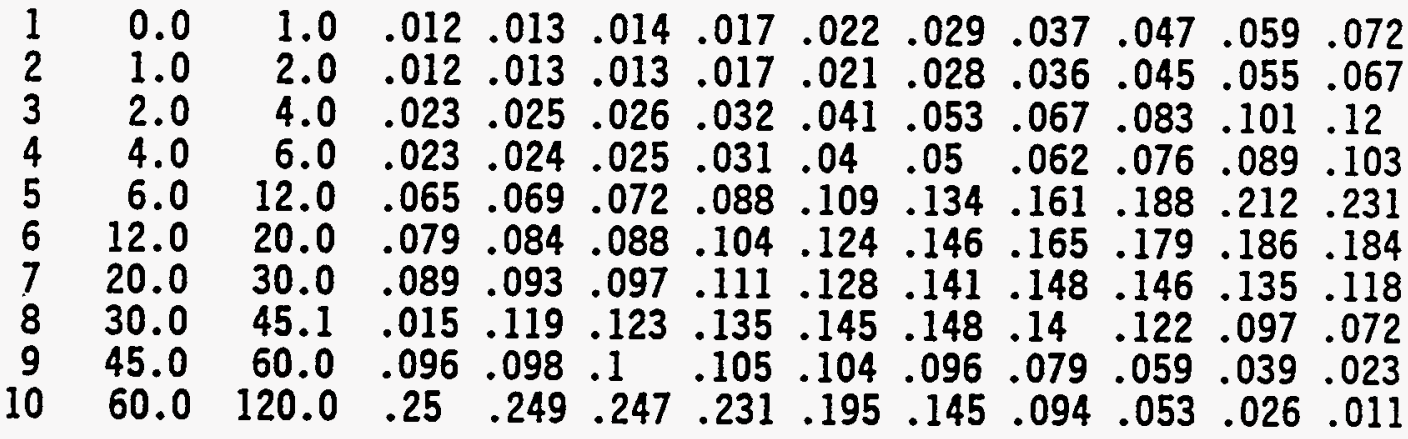


Table A-5

Exfiltration Release Fractions for the Vault Facility

\begin{tabular}{|c|c|c|c|c|c|c|c|c|c|c|c|c|}
\hline Packet & $\begin{array}{l}\text { Begin } \\
\text { Time } \\
\text { (min) }\end{array}$ & $\begin{array}{l}\text { End } \\
\text { Time } \\
\text { (min) }\end{array}$ & 1 & 2 & & 4 & $\begin{array}{l}\text { eed } \\
\quad 5 \\
\end{array}$ & $\mathrm{n} / \mathrm{s}){ }_{6}$ & 7 & 8 & 9 & 10 \\
\hline $\begin{array}{r}1 \\
2 \\
3 \\
4 \\
5 \\
6 \\
7 \\
8 \\
9 \\
10\end{array}$ & $\begin{array}{r}0.0 \\
1.0 \\
2.0 \\
4.0 \\
6.0 \\
12.0 \\
20.0 \\
30.0 \\
45.0 \\
60.0\end{array}$ & $\begin{array}{r}1.0 \\
2.0 \\
4.0 \\
6.0 \\
12.0 \\
20.0 \\
30.0 \\
45.0 \\
60.0 \\
120.0\end{array}$ & $\begin{array}{l}.0001 \\
.0001 \\
.0002 \\
.0002 \\
.0007 \\
.0010 \\
.0012 \\
.0018 \\
.0018 \\
.0073\end{array}$ & $\begin{array}{l}.0002 \\
.0002 \\
.0005 \\
.0005 \\
.0015 \\
.0020 \\
.0024 \\
.0036 \\
.0036 \\
.0144\end{array}$ & $\begin{array}{l}.0004 \\
.0004 \\
.0007 \\
.0007 \\
.0022 \\
.0029 \\
.0036 \\
.0054 \\
.0054 \\
.0214\end{array}$ & $\begin{array}{l}.0005 \\
.0005 \\
.0010 \\
.0010 \\
.0029 \\
.0039 \\
.0048 \\
.0072 \\
.0072 \\
.0282\end{array}$ & $\begin{array}{l}.0006 \\
.0006 \\
.0012 \\
.0012 \\
.0037 \\
.0049 \\
.0060 \\
.0090 \\
.0089 \\
.0348\end{array}$ & $\begin{array}{l}.0007 \\
.0007 \\
.0015 \\
.0015 \\
.0044 \\
.0058 \\
.0072 \\
.0107 \\
.0106 \\
.0414\end{array}$ & $\begin{array}{l}.0009 \\
.0009 \\
.0017 \\
.0017 \\
.0051 \\
.0068 \\
.0084 \\
.0125 \\
.0123 \\
.0477\end{array}$ & $\begin{array}{l}.0010 \\
.0010 \\
.0020 \\
.0020 \\
.0058 \\
.0077 \\
.0096 \\
.0142 \\
.0140 \\
.0539\end{array}$ & $\begin{array}{l}.0011 \\
.0011 \\
.0022 \\
.0022 \\
.0066 \\
.0087 \\
.0107 \\
.0159 \\
.0156 \\
.0600\end{array}$ & $\begin{array}{l}.0012 \\
.0012 \\
.002 \\
.002 \\
.007 \\
.009 \\
.011 \\
.016 \\
.016 \\
.060\end{array}$ \\
\hline
\end{tabular}

Table A-6

Unconfined Release Fractions for the Kiva I Facility

\begin{tabular}{|c|c|c|c|c|c|c|c|c|c|c|c|c|}
\hline $\begin{array}{l}\text { Packet } \\
\text { Number }\end{array}$ & $\begin{array}{l}\text { Begin } \\
\text { Time } \\
\text { (min) }\end{array}$ & $\begin{array}{l}\text { End } \\
\text { Time } \\
\text { (min) }\end{array}$ & 9 & 2 & 3 & $\begin{array}{l}\text { Wind } \\
\quad 4 \\
\end{array}$ & & d 1 & $\begin{array}{r}\text { (s) } \\
\end{array}$ & 8 & 9 & 10 \\
\hline $\begin{array}{l}1 \\
2 \\
3 \\
4\end{array}$ & $\begin{array}{r}0.0 \\
0.5 \\
2.0 \\
10.0\end{array}$ & $\begin{array}{r}0.5 \\
2.0 \\
10.0 \\
30.0\end{array}$ & $\begin{array}{l}.7 \\
.1 \\
.1 \\
.1\end{array}$ & $\begin{array}{l}.7 \\
.1 \\
.1 \\
.1\end{array}$ & $\begin{array}{l}.7 \\
.1 \\
.1 \\
.1\end{array}$ & $\begin{array}{l}.7 \\
.1 \\
.1 \\
.1\end{array}$ & $\begin{array}{l}.7 \\
.1 \\
.1 \\
.1\end{array}$ & $\begin{array}{l}.7 \\
.1 \\
.1 \\
.1\end{array}$ & $\begin{array}{l}.7 \\
.1 \\
.1 \\
.1\end{array}$ & $\begin{array}{l}.7 \\
.1 \\
.1 \\
.1\end{array}$ & $\begin{array}{l}.7 \\
.1 \\
.1 \\
.1\end{array}$ & $\begin{array}{l}.7 \\
.1 \\
.1 \\
.1\end{array}$ \\
\hline
\end{tabular}

Table A-7

List of Initial Radionuclide Inventory

Used in the Fire Accident Scenario at Kiva 1

Radio- Initial

nuclide Activity (Ci)

$\begin{array}{ll}U-234 & 1.38 E-02 \\ U-235 & 4.04 E-04 \\ U-236 & 2.58 E-05 \\ U-238 & 3.64 E-06\end{array}$


Table A-8

List of Initial Radionuclide Inventory

Used in the WINCO Collapse Accident Scenario

Radio- Initial

nuclide Activity (Ci)

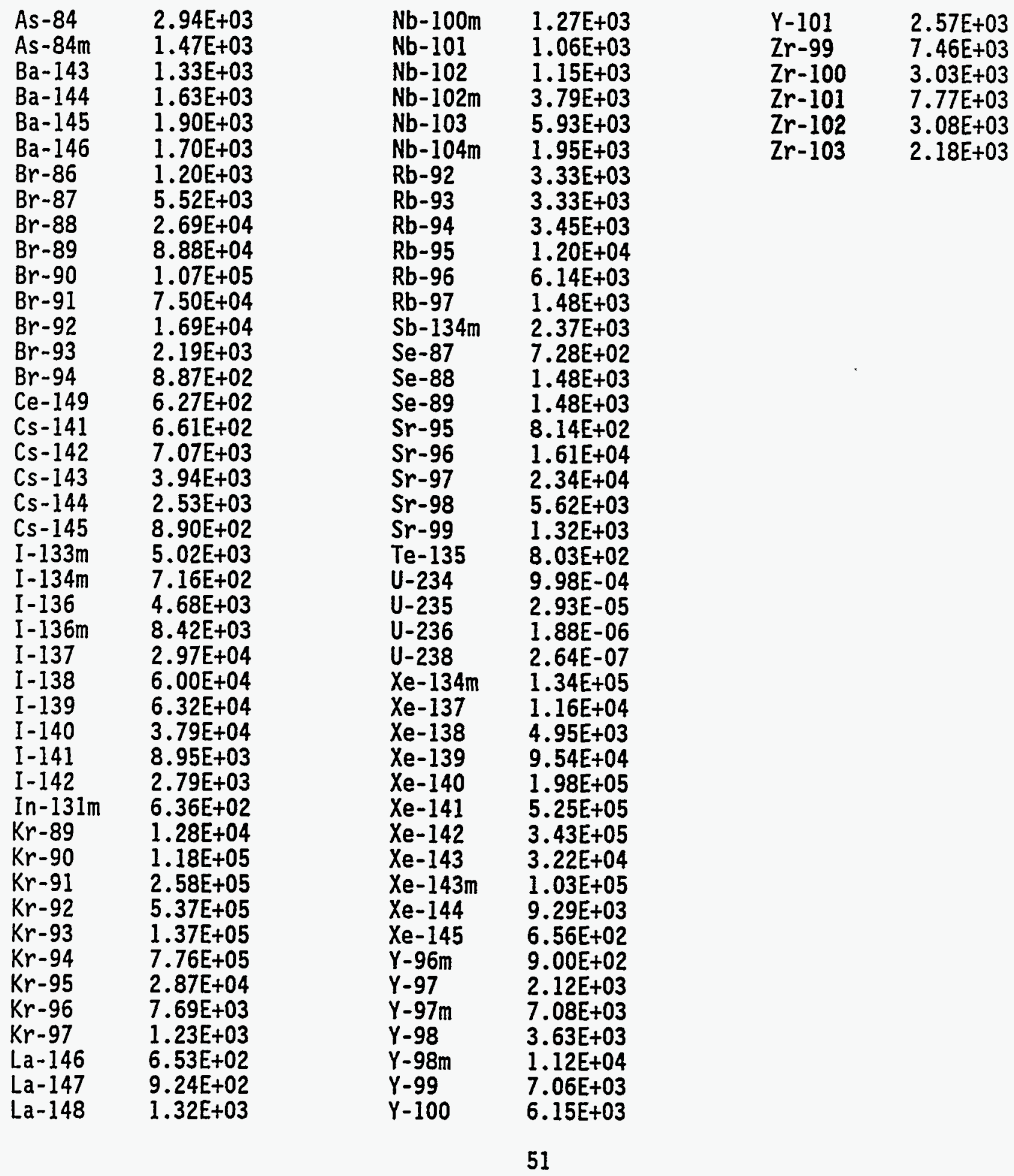


Table A-9

List of Initial Radionuclide Inventory Used in the SHEBA Accident Scenario

Radio- Initial

nuclide Activity (Ci)

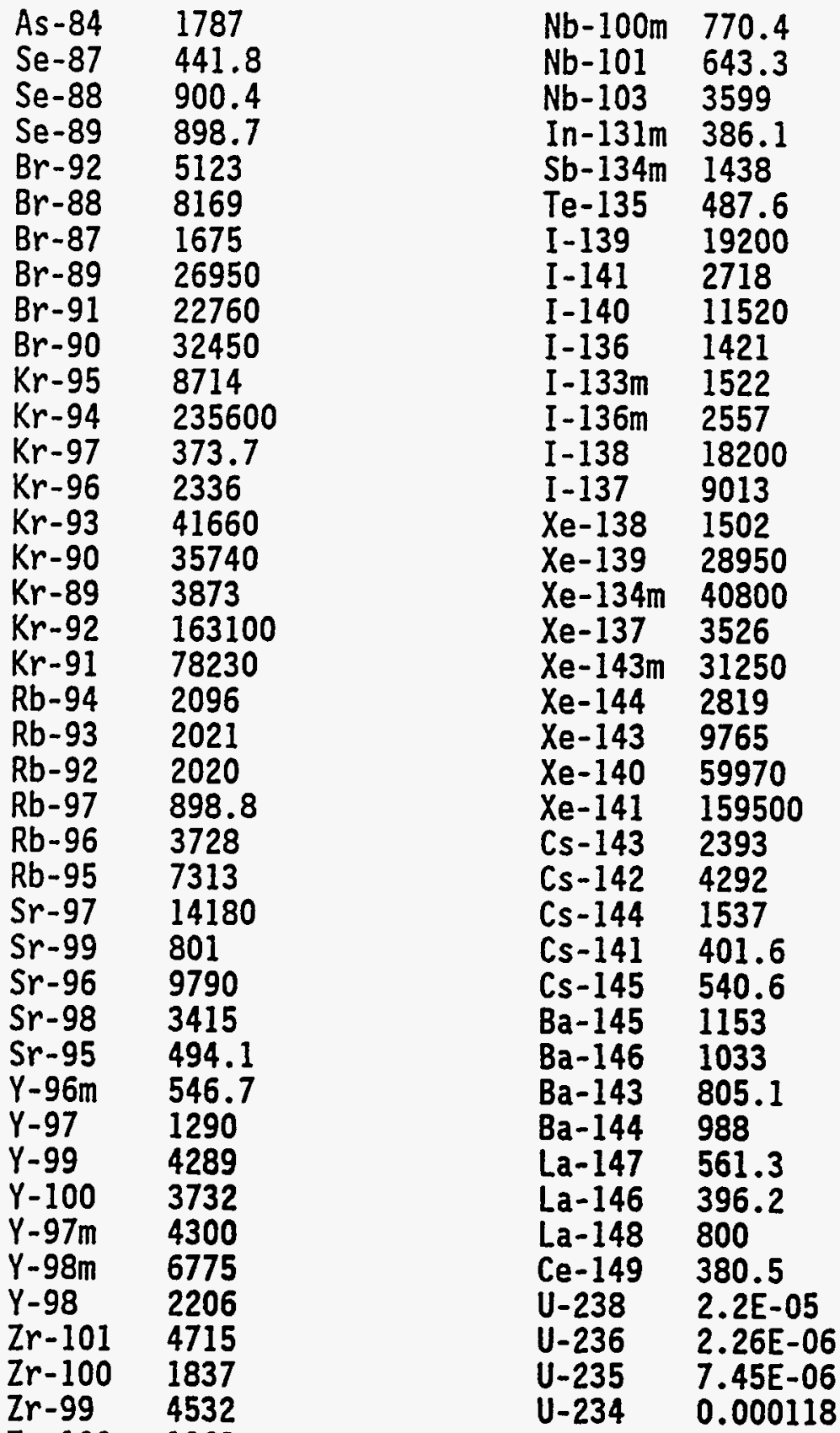

$\mathrm{Zr}-102 \quad 1868$

$\mathrm{Nb}-104 \mathrm{~m} \quad 1187$

$\mathrm{Nb}-102 \quad 696.1$

$\mathrm{Nb}-102 \mathrm{~m} \quad 2303$ 
Table A-10

List of Initial Radionuclide Inventory

Used in the Flattop Accident Scenario at Kiva 2

Radio- - Initial

nuclide Activity (Ci)

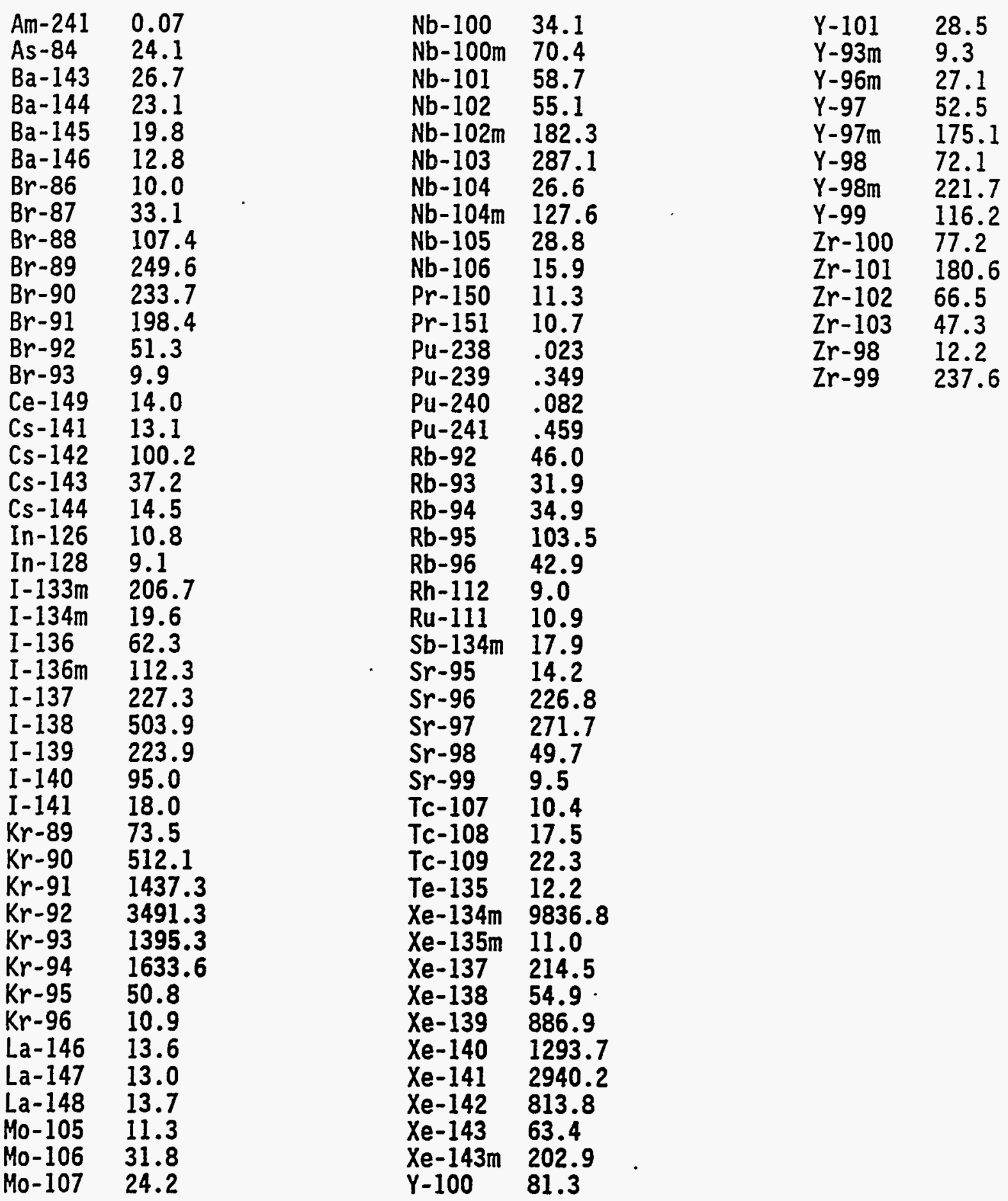


Table A-11

List of Initial Radionuclide Inventory

Used in the Godiva Accident Scenarios

Radio- Initial

nuclide Activity (Ci)

\begin{tabular}{|c|c|c|c|}
\hline $\begin{array}{l}\text { As }-84 \\
\mathrm{As}-84 \mathrm{~m} \\
\mathrm{Ba}-143 \\
\mathrm{Ba}-144 \\
\mathrm{Ba}-145 \\
\mathrm{Ba}-146 \\
\mathrm{Br}-87 \\
\mathrm{Br}-88 \\
\mathrm{Br}-89 \\
\mathrm{Br}-90 \\
\mathrm{Br}-91 \\
\mathrm{Br}-92 \\
\mathrm{Br}-93 \\
\mathrm{Ce}-149 \\
\mathrm{Cs}-141 \\
\mathrm{Cs}-142 \\
\mathrm{Cs}-143 \\
\mathrm{Cs}-144 \\
\mathrm{Cs}-145 \\
\mathrm{I}-133 \mathrm{~m} \\
\mathrm{I}-136 \\
\mathrm{I}-136 \mathrm{~m} \\
\mathrm{I}-137 \\
\mathrm{I}-138 \\
\mathrm{I}-139 \\
\mathrm{I}-140 \\
\mathrm{I}-141 \\
\mathrm{I}-142 \\
\mathrm{I} n-131 \mathrm{~m} \\
\mathrm{Kr}-89 \\
\mathrm{Kr}-90 \\
\mathrm{Kr}-91 \\
\mathrm{Kr}-92 \\
\mathrm{Kr}-93 \\
\mathrm{Kr}-94 \\
\mathrm{Kr}-95 \\
\mathrm{Kr}-96 \\
\mathrm{Kr}-97 \\
\mathrm{La}-146 \\
\mathrm{La}-147 \\
\mathrm{La}-148 \\
\mathrm{Nb}-100 \mathrm{~m} \\
\mathrm{Nh}-101\end{array}$ & $\begin{array}{l}1.54 E+03 \\
7.69 E+02 \\
6.93 E+02 \\
8.50 E+02 \\
9.92 E+02 \\
8.89 E+02 \\
1.44 E+03 \\
7.03 E+03 \\
2.32 E+04 \\
2.79 E+04 \\
1.96 E+04 \\
4.41 E+03 \\
5.71 E+02 \\
3.27 E+02 \\
3.46 E+02 \\
3.69 E+03 \\
2.06 E+03 \\
1.32 E+03 \\
4.65 E+02 \\
1.31 E+03 \\
1.22 E+03 \\
2.20 E+03 \\
7.75 E+03 \\
1.57 E+04 \\
1.65 E+04 \\
9.91 E+03 \\
2.34 E+03 \\
7.27 E+02 \\
3.32 E+02 \\
3.33 E+03 \\
3.08 E+04 \\
6.73 E+04 \\
1.40 E+05 \\
3.58 E+04 \\
2.03 E+05 \\
7.50 E+03 \\
2.01 E+03 \\
3.22 E+02 \\
3.41 E+02 \\
4.83 E+02 \\
6.88 E+02 \\
6.63 E+02 \\
5.53 E+02\end{array}$ & $\begin{array}{l}N b-102 \\
N b-102 m \\
N b-103 \\
N b-104 m \\
R b-92 \\
R b-93 \\
R b-94 \\
R b-95 \\
R b-96 \\
R b-97 \\
S b-134 m \\
S e-87 \\
S e-88 \\
S e-89 \\
S r-95 \\
S r-96 \\
S r-97 \\
S r-98 \\
S r-99 \\
T e-135 \\
U-234 \\
U-235 \\
U-236 \\
U-238 \\
X e-134 m \\
X e-137 \\
X e-138 \\
X e-139 \\
X e-140 \\
X e-141 \\
X e-142 \\
X e-143 \\
X e-143 m \\
X e-144 \\
Y-96 m \\
Y-97 \\
Y-97 m \\
Y-98 \\
Y-98 m \\
Y-99 \\
Y-100 \\
Y-101 \\
Z r-99 \\
\text { Zr }\end{array}$ & $\begin{array}{l}5.99 E+02 \\
1.98 E+03 \\
3.10 E+03 \\
1.02 E+03 \\
1.74 E+03 \\
1.74 E+03 \\
1.80 E+03 \\
6.29 E+03 \\
3.21 E+03 \\
7.73 E+02 \\
1.24 E+03 \\
3.80 E+02 \\
7.75 E+02 \\
7.73 E+02 \\
4.25 E+02 \\
8.42 E+03 \\
1.22 E+04 \\
2.94 E+03 \\
6.89 E+02 \\
4.20 E+02 \\
4.54 E-03 \\
1.33 E-04 \\
8.51 E-06 \\
1.20 E-06 \\
3.51 E+04 \\
3.03 E+03 \\
1.29 E+03 \\
2.49 E+04 \\
5.16 E+04 \\
1.37 E+05 \\
8.95 E+04 \\
8.40 E+03 \\
2.69 E+04 \\
2.43 E+03 \\
4.70 E+02 \\
1.11 E+03 \\
3.70 E+03 \\
1.90 E+03 \\
5.83 E+03 \\
3.69 E+03 \\
3.21 E+03 \\
1.34 E+03 \\
3.90 E+03\end{array}$ \\
\hline
\end{tabular}

$\mathrm{Zr}-100 \quad 1.58 \mathrm{E}+03$

$\mathrm{Zr}-101 \quad 4.06 \mathrm{E}+03$

$\mathrm{Zr}-102 \quad 1.61 \mathrm{E}+03$

$\mathrm{Zr}-103 \quad 1.14 \mathrm{E}+03$ 
Table A-12

List of Initial Radionuclide Inventory Used in the SKUA Accident Scenario at Kiva 3

Radio- Initial

nuclide Activity ( $\mathrm{C} i$ )

\begin{tabular}{|c|c|c|c|c|c|}
\hline $\begin{array}{l}\text { Am-241 } \\
\text { As-84 } \\
\text { As- }-84 m \\
\mathrm{Ba}-143 \\
\mathrm{Ba}-144 \\
\mathrm{Ba}-145 \\
\mathrm{Ba}-146 \\
\mathrm{Br}-86 \\
\mathrm{Br}-87 \\
\mathrm{Br}-88 \\
\mathrm{Br}-89 \\
\mathrm{Br}-90 \\
\mathrm{Br}-91 \\
\mathrm{Br}-92 \\
\mathrm{Br}-93 \\
\mathrm{Ce}-149 \\
\mathrm{Cs}-141 \\
\mathrm{Cs}-142 \\
\mathrm{Cs}-143 \\
\mathrm{Cs}-144 \\
\mathrm{I}-133 \mathrm{~m} \\
\mathrm{I}-134 \mathrm{~m} \\
\mathrm{I}-136 \\
\mathrm{I}-136 \mathrm{~m} \\
\mathrm{I}-137 \\
\mathrm{I}-138 \\
\mathrm{I}-139 \\
\mathrm{I}-140 \\
\mathrm{I}-141 \\
\mathrm{I} n-126 \\
\mathrm{In}-128 \\
\mathrm{Kr}-89 \\
\mathrm{Kr}-90 \\
\mathrm{Kr}-91 \\
\mathrm{Kr}-92 \\
\mathrm{Kr}-93 \\
\mathrm{Kr}-94 \\
\mathrm{Kr}-95 \\
\mathrm{Kr}-96 \\
\mathrm{La}-146 \\
\mathrm{La}-147 \\
\mathrm{La}-148 \\
\mathrm{Mo}-105\end{array}$ & $\begin{array}{l}0.0716 \\
11.4 \\
5.7 \\
12.6 \\
10.9 \\
9.3 \\
6.0 \\
4.7 \\
15.7 \\
50.8 \\
118.0 \\
110.5 \\
93.8 \\
24.3 \\
4.7 \\
6.6 \\
6.2 \\
47.4 \\
17.6 \\
6.8 \\
97.7 \\
9.3 \\
29.4 \\
53.1 \\
107.4 \\
238.2 \\
105.8 \\
44.9 \\
8.5 \\
5.1 \\
4.3 \\
34.8 \\
242.0 \\
679.4 \\
1650.2 \\
659.5 \\
772.2 \\
24.0 \\
5.1 \\
6.4 \\
6.2 \\
6.5 \\
5.3\end{array}$ & 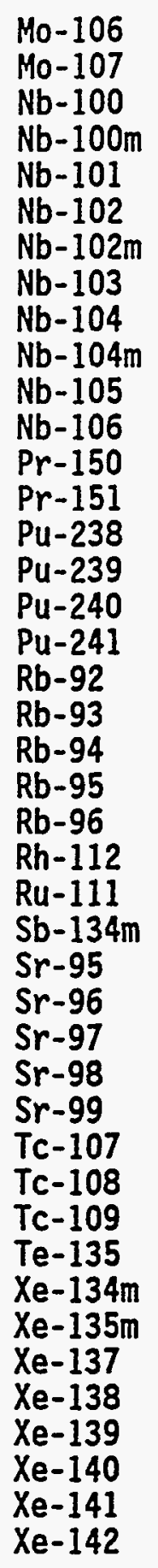 & $\begin{array}{l}15.1 \\
11.4 \\
16.1 \\
33.3 \\
27.7 \\
26.1 \\
86.2 \\
135.7 \\
12.6 \\
60.3 \\
13.6 \\
7.5 \\
5.4 \\
5.1 \\
0.0234 \\
0.3490 \\
0.0818 \\
0.4592 \\
21.7 \\
15.1 \\
16.5 \\
48.9 \\
20.3 \\
4.2 \\
5.2 \\
8.5 \\
6.7 \\
107.2 \\
128.4 \\
23.5 \\
4.5 \\
4.9 \\
8.3 \\
10.5 \\
5.8 \\
4649.6 \\
5.2 \\
101.4 \\
25.9 \\
419.2 \\
611.5 \\
1389.8 \\
384.6\end{array}$ & $\begin{array}{l}X e-143 \\
X e-143 m \\
Y-93 m \\
Y-96 m \\
Y-97 \\
Y-97 m \\
Y-98 \\
Y-98 m \\
Y-99 \\
Y-100 \\
Y-101 \\
Z r-98 \\
Z r-99 \\
Z r-100 \\
Z r-101 \\
Z r-102 \\
Z r-103\end{array}$ & $\begin{array}{l}30.0 \\
95.9 \\
4.4 \\
12.8 \\
24.8 \\
82.8 \\
34.1 \\
104.8 \\
54.9 \\
38.4 \\
13.5 \\
5.8 \\
112.3 \\
36.5 \\
85.3 \\
31.4 \\
22.3\end{array}$ \\
\hline
\end{tabular}


Table A-13

List of Initial Radionuclide Inventory

Used in the Vault Collapse Accident Scenario

Radio- Initial

nuclide Activity ( $C$ i)

U-234 6.88E-03

U-235 2.02E-04

U-236 1.29E-05

U-238 1.82E-06

$\mathrm{Pu}-238 \quad 3.90 \mathrm{e}-02$

$\mathrm{Pu}-239 \quad 5.82 \mathrm{e}-01$

$\mathrm{Pu}-240 \quad 1.36 \mathrm{e}-01$

Pu-241 7.65e-01

Am-241 $1.19 \mathrm{e}-01$ 


\section{Table A-14}

Radionuclide Decay Data ${ }^{9}$

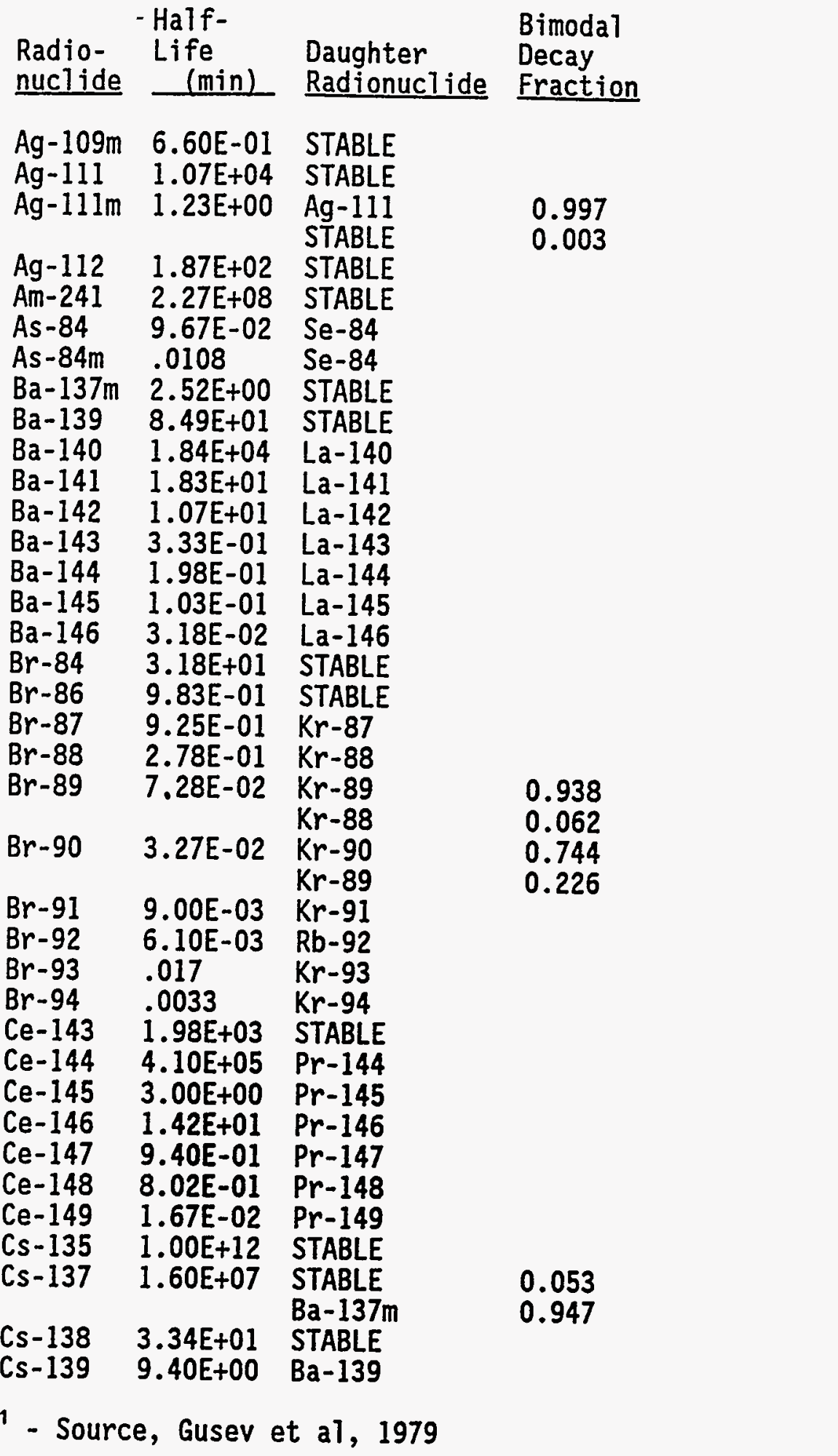




\begin{tabular}{|c|c|c|c|}
\hline $\begin{array}{l}\text { Radio- } \\
\text { nuclide }\end{array}$ & $\begin{array}{l}\text { Half- } \\
\text { Life } \\
\quad(\min )\end{array}$ & $\begin{array}{l}\text { Daughter } \\
\text { Radionuclide }\end{array}$ & $\begin{array}{l}\text { Bimodal } \\
\text { Decay } \\
\text { Fraction }\end{array}$ \\
\hline $\begin{array}{l}C s-140 \\
C s-141 \\
C s-142 \\
C s-143 \\
C s-144 \\
C s-145 \\
I-131 \\
I-133\end{array}$ & $\begin{array}{l}1.12 E+00 \\
4.16 E-01 \\
2.82 E-02 \\
2.97 E-02 \\
1.67 E-02 \\
9.70 E-03 \\
1.16 E+04 \\
1.25 E+03\end{array}$ & $\begin{array}{l}\mathrm{Ba}-140 \\
\mathrm{Ba}-141 \\
\mathrm{Ba}-142 \\
\mathrm{Ba}-143 \\
\mathrm{Ba}-144 \\
\mathrm{Ba}-145 \\
\text { STABLE } \\
\mathrm{Xe}-133 \\
\mathrm{Xe}-133 \mathrm{~m}\end{array}$ & $\begin{array}{l}0.9712 \\
0.0288\end{array}$ \\
\hline $\begin{array}{l}I-133 m \\
I-134 \\
I-134 m\end{array}$ & $\begin{array}{l}1.50 E-01 \\
5.26 E+01 \\
3.56 E+00\end{array}$ & $\begin{array}{l}\text { I-133 } \\
\text { STABLE } \\
\text { I- } 134\end{array}$ & 0.98 \\
\hline$I-135$ & $3.97 E+02$ & $\begin{array}{l}\mathrm{Xe}-135 \\
\mathrm{Xe}-135 \mathrm{~m}\end{array}$ & $\begin{array}{l}0.835 \\
0.165\end{array}$ \\
\hline $\begin{array}{l}I-136 \\
I-136 m\end{array}$ & $\begin{array}{l}7.67 \mathrm{E}-01 \\
1.38 \mathrm{E}+00\end{array}$ & $\begin{array}{l}\text { STABLE } \\
\text { I-136 } \\
\text { STABLE }\end{array}$ & $\begin{array}{l}0.2 \\
0.8\end{array}$ \\
\hline $\begin{array}{l}I-137 \\
I-138 \\
I-139 \\
I-140 \\
I-141 \\
I-142 \\
I n-126 \\
I n-128 \\
I n-13 I m \\
K r-87 \\
K r-88 \\
K r-89 \\
K r-90\end{array}$ & $\begin{array}{l}3.67 \mathrm{E}-01 \\
1.08 \mathrm{E}-01 \\
3.83 \mathrm{E}-02 \\
9.80 \mathrm{E}-03 \\
8.00 \mathrm{E}-03 \\
8.05 \mathrm{E}-03 \\
2.55 \mathrm{E}-02 \\
1.83 \mathrm{E}-01 \\
5.00 \mathrm{E}-03 \\
7.63 \mathrm{E}+01 \\
1.70 \mathrm{E}+02 \\
3.07 \mathrm{E}+00 \\
5.39 \mathrm{E}-01\end{array}$ & $\begin{array}{l}\mathrm{Xe}-137 \\
\mathrm{Xe}-138 \\
\mathrm{Xe}-139 \\
\mathrm{Xe}-140 \\
\mathrm{Xe}-141 \\
\mathrm{Xe}-142 \\
\mathrm{Sn}-126 \\
\mathrm{Sn}-128 \\
\mathrm{Sn}-131 \\
\mathrm{Rb}-87 \\
\mathrm{Rb}-88 \\
\mathrm{Rb}-89 \\
\mathrm{Rb}-90 \mathrm{~m} \\
\mathrm{Rb}-90\end{array}$ & $\begin{array}{l}0.2116 \\
0.7884\end{array}$ \\
\hline $\begin{array}{l}\mathrm{Kr}-91 \\
\mathrm{Kr}-92 \\
\mathrm{Kr}-93 \\
\mathrm{Kr}-94 \\
\mathrm{Kr}-95 \\
\mathrm{Kr}-96 \\
\mathrm{Kr}-97 \\
\mathrm{La}-140 \\
\mathrm{La}-141 \\
\mathrm{La}-142 \\
\mathrm{La}-143 \\
\mathrm{La}-144 \\
\mathrm{La}-145 \\
\mathrm{La}-146 \\
\mathrm{La}-147\end{array}$ & $\begin{array}{l}1.44 E-01 \\
3.07 E-02 \\
2.12 E-02 \\
3.70 E-03 \\
1.30 E-02 \\
8.30 E-03 \\
1.70 E-03 \\
2.42 E+03 \\
2.36 E+02 \\
9.20 E+01 \\
1.43 E+01 \\
6.78 E-01 \\
5.50 E-01 \\
1.47 E-01 \\
2.17 E-01 \\
H a 7 f-\end{array}$ & $\begin{array}{l}\text { Rb-91 } \\
\text { Rb-92 } \\
\text { Sr-93 } \\
\text { Rb-94 } \\
\text { Sr-95 } \\
\text { Rb-96 } \\
\text { Rb-97 } \\
\text { STABLE } \\
\text { STABLE } \\
\text { STABLE } \\
\text { Ce-143 } \\
\text { Ce-144 } \\
\text { Ce-145 } \\
\text { Ce-146 } \\
\text { Ce-147 }\end{array}$ & Bimodal \\
\hline
\end{tabular}




\begin{tabular}{|c|c|c|c|}
\hline $\begin{array}{l}\text { Radio- } \\
\text { nuclide }\end{array}$ & $\begin{array}{l}\text { Life } \\
\quad(\min ) \\
\end{array}$ & $\begin{array}{l}\text { Daughter } \\
\text { Radionuclide }\end{array}$ & $\begin{array}{l}\text { Decay } \\
\text { Fraction }\end{array}$ \\
\hline $\begin{array}{l}\text { La-148 } \\
\text { Mo-100 } \\
M o-101 \\
\text { Mo-101 } \\
M o-102 \\
\text { Mo-103 } \\
\text { Mo-104 } \\
\text { Mo-105 } \\
\text { Mo-106 } \\
\text { Mo-107 } \\
M o-99 \\
\mathrm{Nb}-100 \\
\mathrm{Nb}-100 \mathrm{~m} \\
\mathrm{Nb}-101 \\
\mathrm{Nb}-102 \\
\mathrm{Nb}-102 \mathrm{~m} \\
\mathrm{Nb}-103 \\
\mathrm{Nb}-104 \\
\mathrm{Nb}-104 \mathrm{~m} \\
\mathrm{Nb}-105 \\
\mathrm{Nb}-106 \\
\mathrm{Nb}-95 \\
\mathrm{Nb}-95 \mathrm{~m} \\
\mathrm{Nb}-97 \\
\mathrm{Nb}-97 \mathrm{~m} \\
\mathrm{Nb}-98 \\
\mathrm{Nb}-98 \mathrm{~m} \\
\mathrm{Nb}-99 \\
\mathrm{Nb}-99 \mathrm{~m}\end{array}$ & $\begin{array}{r}2.15 \mathrm{E}-02 \\
-1.58 \mathrm{E}+23 \\
1.46 \mathrm{E}+01 \\
1.46 \mathrm{E}+01 \\
1.18 \mathrm{E}+01 \\
1.00 \mathrm{E}+00 \\
1.30 \mathrm{E}+00 \\
7.00 \mathrm{E}-01 \\
1.58 \mathrm{E}-01 \\
4.83 \mathrm{E}-02 \\
3.96 \mathrm{E}+03 \\
3.10 \mathrm{E}+00 \\
4.67 \mathrm{E}-02 \\
1.18 \mathrm{E}-01 \\
7.17 \mathrm{E}-02 \\
2.17 \mathrm{E}-02 \\
2.50 \mathrm{E}-02 \\
8.00 \mathrm{E}-02 \\
1.33 \mathrm{E}-02 \\
3.00 \mathrm{E}-02 \\
1.67 \mathrm{E}-02 \\
5.04 \mathrm{E}+04 \\
5.20 \mathrm{E}+03 \\
7.21 \mathrm{E}+01 \\
1.00 \mathrm{E}+00 \\
4.77 \mathrm{E}-02 \\
5.13 \mathrm{E}+01 \\
2.50 \mathrm{E}-01 \\
4.33 \mathrm{E}-02\end{array}$ & $\begin{array}{l}\text { Ce-148 } \\
\text { STABLE } \\
\text { Tc-101 } \\
\text { Tc-101 } \\
\text { Tc-102 } \\
\text { Tc-103 } \\
\text { Tc-104 } \\
\text { Tc-105 } \\
\text { Tc-106 } \\
\text { Tc-107 } \\
\text { STABLE } \\
\text { Mo-100 } \\
\text { Mo-100 } \\
\text { Mo-101 } \\
\text { Mo-102 } \\
\text { Mo-102 } \\
\text { Mo-103 } \\
\text { Mo-104 } \\
\text { Mo-104 } \\
\text { Mo-105 } \\
\text { Mo-106 } \\
\text { STABLE } \\
\text { Nb-95 } \\
\text { STABLE } \\
\text { Nb-97 } \\
\text { STABLE } \\
\text { Nb-98 } \\
\text { Mo-99 } \\
\text { Mo-99 } \\
\text { Tc-99 }\end{array}$ & $\begin{array}{l}0.5 \\
0.5\end{array}$ \\
\hline $\begin{array}{l}N d-144 \\
N d-147 \\
N d-149 \\
N d-150 \\
N d-151 \\
N p-237 \\
P d-107 \\
P d-109\end{array}$ & $\begin{array}{l}1.20 E+21 \\
1.58 E+04 \\
1.04 E+02 \\
2.63 E+23 \\
1.24 E+01 \\
1.12 E+12 \\
3.42 E+12 \\
8.08 E+02\end{array}$ & $\begin{array}{l}\text { STABLE } \\
\text { Pm-147 } \\
\text { Pm-149 } \\
\text { STABLE } \\
\text { Pm-151 } \\
\text { STABLE } \\
\text { STABLE } \\
\text { STABLE } \\
\text { Aa-109m }\end{array}$ & 0.00051 \\
\hline $\begin{array}{l}\mathrm{Pd}-111 \mathrm{~m} \\
\mathrm{Pd}-111\end{array}$ & $\begin{array}{l}330 \\
2.20 E+01\end{array}$ & $\begin{array}{l}\mathrm{Ag}-111 \mathrm{~m} \\
\mathrm{Pd}-111 \\
\mathrm{Ag}-111 \\
\mathrm{Ag}-111 \mathrm{~m}\end{array}$ & $\begin{array}{l}0.217 \\
0.713 \\
0.0072 \\
0.9928\end{array}$ \\
\hline $\begin{array}{l}P d-112 \\
P m-147 \\
P m-149\end{array}$ & $\begin{array}{l}1.27 E+03 \\
1.40 E+06 \\
3.18 E+03\end{array}$ & $\begin{array}{l}\text { Ag-112 } \\
\text { STABLE } \\
\text { Sm- } 149\end{array}$ & \\
\hline Radio- & $\begin{array}{l}\text { Half- } \\
\text { Life }\end{array}$ & Daughter & $\begin{array}{l}\text { Bimodal } \\
\text { Decay }\end{array}$ \\
\hline
\end{tabular}




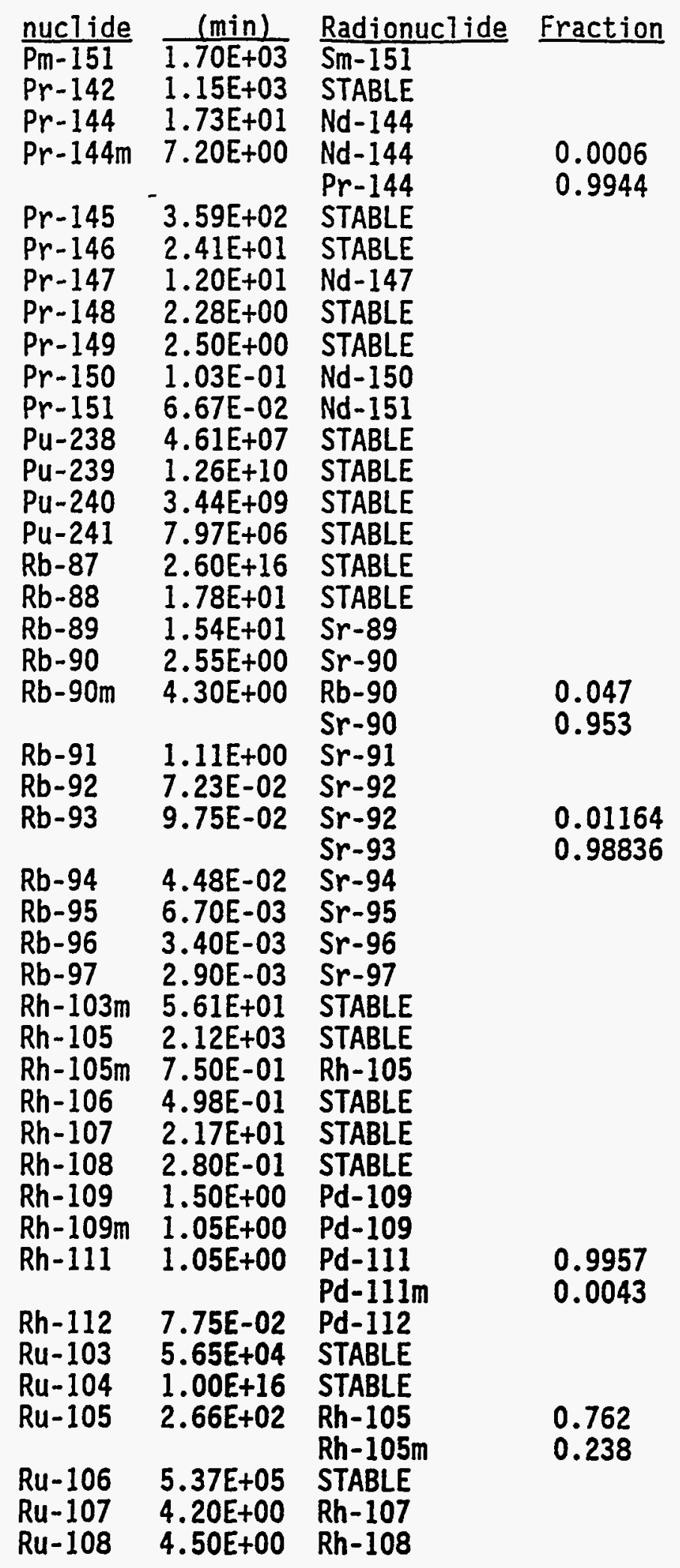




\begin{tabular}{|c|c|c|c|}
\hline $\begin{array}{l}\text { Radio- } \\
\text { nuclide }\end{array}$ & $\begin{array}{l}\text { Half- } \\
\text { Life } \\
(\min ) \\
\end{array}$ & $\begin{array}{l}\text { Daughter } \\
\text { Radionuclide }\end{array}$ & $\begin{array}{l}\text { Bimodal } \\
\text { Decay } \\
\text { Fraction }\end{array}$ \\
\hline$R u-109$ & $5.75 E-01$ & $\begin{array}{l}\text { Rh-109 } \\
\text { Rh-109m }\end{array}$ & $\begin{array}{l}0.5 \\
0.5\end{array}$ \\
\hline $\begin{array}{l}\text { Ru-111 } \\
\text { Sb-128 } \\
\text { Sb-128m }\end{array}$ & $\begin{array}{l}1.67 E-02 \\
5.46 E+02 \\
1.00 E+01\end{array}$ & $\begin{array}{l}\text { Rh-111 } \\
\text { STABLE } \\
\text { Sb-128 } \\
\text { STABLE }\end{array}$ & $\begin{array}{l}0.036 \\
0.946\end{array}$ \\
\hline$S b-131$ & $1.30 E+01$ & $\begin{array}{l}\text { Te-131 } \\
\text { Te-131m }\end{array}$ & $\begin{array}{l}0.901 \\
0.099\end{array}$ \\
\hline $\begin{array}{l}\text { Sb- } 134 m \\
\text { Se-84 } \\
\text { Se-87 } \\
\text { Se-88 } \\
\text { Se-89 } \\
\text { Sm-149 } \\
\text { Sm-151 } \\
\text { Sn-126 } \\
\text { Sn-128 } \\
\text { Sn-131 } \\
\text { Sr-89 } \\
\text { Sr-90 } \\
\text { Sr-91 }\end{array}$ & $\begin{array}{l}1.42 E-02 \\
3.30 E+00 \\
9.58 E-02 \\
2.55 E-02 \\
6.80 E-03 \\
1.00 E+16 \\
4.73 E+07 \\
5.26 E+11 \\
5.93 E+01 \\
1.08 E+00 \\
7.27 E+04 \\
1.52 E+07 \\
5.85 E+02\end{array}$ & $\begin{array}{l}\text { Te-134 } \\
\text { Br-84 } \\
\text { Br-87 } \\
\text { Br-88 } \\
\text { Br-89 } \\
\text { STABLE } \\
\text { STABLE } \\
\text { STABLE } \\
\text { Sb-128m } \\
\text { Sb-131 } \\
\text { STABLE } \\
\text { STABLE } \\
\text { Y-91 } \\
\text { Y-91m }\end{array}$ & $\begin{array}{l}0.424 \\
0.576\end{array}$ \\
\hline $\begin{array}{l}5 r-92 \\
S r-93 \\
S r-93\end{array}$ & $\begin{array}{l}1.63 E+02 \\
7.43 E+00 \\
7.43 E+00\end{array}$ & $\begin{array}{l}y-91 m \\
y-92 \\
y-93 \\
y-93 \\
y-93 m\end{array}$ & $\begin{array}{l}0.5 \\
0.5\end{array}$ \\
\hline $\begin{array}{l}\text { Sr-94 } \\
\text { Sr-95 } \\
\text { Sr-96 } \\
\text { Sr-97 } \\
\text { Sr-98 } \\
\text { Sr-99 } \\
\text { Tc-101 } \\
\text { Tc-102 } \\
\text { Tc-103 } \\
\text { Tc-104 } \\
\text { Tc-105 } \\
\text { Tc-106 } \\
\text { Tc-107 } \\
\text { Tc-108 } \\
\text { Tc-109 } \\
\text { Tc-99 } \\
\text { Tc-99m } \\
\text { Te-131 } \\
T e-131 \mathrm{~m} \\
\text { Te-134 } \\
\text { Te-135 }\end{array}$ & $\begin{array}{l}1.24 \mathrm{E}+00 \\
4.07 \mathrm{E}-01 \\
1.67 \mathrm{E}-02 \\
6.70 \mathrm{E}-03 \\
1.08 \mathrm{E}-02 \\
1.00 \mathrm{E}-02 \\
1.42 \mathrm{E}+01 \\
8.80 \mathrm{E}-02 \\
8.42 \mathrm{E}-01 \\
1.82 \mathrm{E}+01 \\
7.60 \mathrm{E}+00 \\
6.00 \mathrm{E}-01 \\
4.83 \mathrm{E}-01 \\
8.75 \mathrm{E}-02 \\
2.33 \mathrm{E}-02 \\
1.10 \mathrm{E}+11 \\
3.60 \mathrm{E}+02 \\
2.50 \mathrm{E}+01 \\
4.67 \mathrm{E}+04 \\
4.18 \mathrm{E}+01 \\
3.00 \mathrm{E}-01 \\
\mathrm{Ha} \mathrm{f}-\end{array}$ & $\begin{array}{l}\text { Y-94 } \\
\text { Y-95 } \\
\text { Y-96 } \\
\text { Y-97 } \\
\text { Y-98 } \\
\text { Y-99 } \\
\text { STABLE } \\
\text { STABLE } \\
\text { Ru-103 } \\
\text { Ru-104 } \\
\text { Ru-105 } \\
\text { Ru-106 } \\
\text { Ru-107 } \\
\text { Ru-108 } \\
\text { Ru-109 } \\
\text { STABLE } \\
\text { STABLE } \\
\text { STABLE } \\
\text { STABLE } \\
\text { I-134 } \\
\text { I-135 }\end{array}$ & Bimoda1 \\
\hline
\end{tabular}




\begin{tabular}{|c|c|c|c|}
\hline $\begin{array}{l}\text { Radio- } \\
\text { nuclide }\end{array}$ & $\begin{array}{l}\text { Life } \\
\quad(\min )\end{array}$ & $\begin{array}{l}\text { Daughter } \\
\text { Radionuclide }\end{array}$ & $\begin{array}{l}\text { Decay } \\
\text { Fraction }\end{array}$ \\
\hline $\begin{array}{l}\text { Th-230 } \\
\text { Th-231 } \\
T h-232 \\
T h-234 \\
U-233 \\
U-234 \\
U-235 \\
U-236 \\
U-238 \\
X e-133 \\
X e-133 m \\
X e-134 m \\
X e-135 \\
X e-135 m \\
\\
X e-137 \\
X e-138 \\
X e-139 \\
X e-140 \\
X e-141 \\
X e-142 \\
X e-143 \\
X e-143 m \\
X e-144 \\
X e-145 \\
Y-100 \\
Y-101 \\
Y-91 \\
Y-91 m \\
Y-92 \\
Y-93 \\
Y-93 m \\
Y-94 \\
Y-95 \\
Y-96 \\
Y-96 m \\
Y-97 \\
Y-97 m \\
Y-98 \\
Y-98 m \\
Y-99 \\
Y-100 \\
Y-101 \\
Z r-100 \\
Z r-101 \\
Z r-102 \\
Z r-103 \\
\text { Y }\end{array}$ & $\begin{array}{l}4.05 E+10 \\
1.53 E+03 \\
7.38 E+15 \\
3.47 E+04 \\
8.30 E+10 \\
1.30 E+11 \\
3.70 E+14 \\
1.23 E+13 \\
2.30 E+15 \\
7.60 E+03 \\
3.20 E+03 \\
4.83 E-03 \\
5.45 E+02 \\
1.57 E+01 \\
3.83 E+00 \\
1.41 E+01 \\
6.58 E-01 \\
2.67 E-01 \\
2.87 E-02 \\
2.03 E-02 \\
5.00 E-03 \\
1.60 E-02 \\
1.92 E-02 \\
.015 \\
8.30 E-03 \\
1.67 E-02 \\
8.42 E+04 \\
4.97 E+01 \\
2.12 E+02 \\
6.12 E+02 \\
1.37 E-02 \\
1.91 E+01 \\
1.03 E+01 \\
2.30 E+00 \\
1.00 E-01 \\
1.85 E-02 \\
1.67 E-02 \\
3.33 E-02 \\
1.08 E-02 \\
2.42 E-02 \\
.008 \\
.008 \\
1.18 E-01 \\
5.50 E-02 \\
1.33 E-02 \\
1.67 E-02\end{array}$ & $\begin{array}{l}\text { STABLE } \\
\text { STABLE } \\
\text { STABLE } \\
\text { STABLE } \\
\text { STABLE } \\
\text { Th-230 } \\
\text { STABLE } \\
\text { STABLE } \\
\text { Th-234 } \\
\text { STABLE } \\
\text { Xe-133 } \\
\text { STABLE } \\
\text { Cs-135 } \\
\text { Cs-135 } \\
\text { Xe-135 } \\
\text { Cs-137 } \\
\text { Cs-138 } \\
\text { Cs-139 } \\
\text { Cs-140 } \\
\text { Cs-141 } \\
\text { Cs-142 } \\
\text { Ba-143 } \\
\text { Ba-143 } \\
\text { Ba-144 } \\
\text { Cs-145 } \\
\text { Zr-100 } \\
\text { Zr-101 } \\
\text { STABLE } \\
Y-91 \\
\text { STABLE } \\
\text { Zr-93 } \\
\text { Y-93 } \\
\text { STABLE } \\
\text { Zr-95 } \\
\text { STABLE } \\
\text { STABLE } \\
\text { Zr-97 } \\
Y-97 \\
\text { Zr-98 } \\
\text { Zr-98 } \\
\text { Zr-99 } \\
\text { Zr-100 } \\
\text { Zr-101 } \\
\text { Nb-100m } \\
\text { Nb-101 } \\
\text { Nb-102 } \\
\text { Nb-103 }\end{array}$ & $\begin{array}{l}0.004 \\
0.996\end{array}$ \\
\hline Radio- & $\begin{array}{l}\text { Half- } \\
\text { Life }\end{array}$ & & $\begin{array}{l}\text { Bimodal } \\
\text { Decay }\end{array}$ \\
\hline
\end{tabular}




\begin{tabular}{|c|c|c|c|}
\hline nuclide & $(\min )$ & Radionuclide & Fraction \\
\hline $\begin{array}{l}\mathrm{Zr}-93 \\
\mathrm{Zr}-95\end{array}$ & $\begin{array}{l}7.88 E+11 \\
9.22 E+04\end{array}$ & $\begin{array}{l}\text { STABLE } \\
\mathrm{Nb}-95 \\
\mathrm{Nb}-95 \mathrm{~m}\end{array}$ & $\begin{array}{l}0.994 \\
0.006\end{array}$ \\
\hline $\begin{array}{l}Z r-97 \\
Z r-98\end{array}$ & $\begin{array}{l}1.01 E+03 \\
5.12 E-01\end{array}$ & $\begin{array}{l}\text { STABLE } \\
\text { Nb-98 } \\
\text { Nh-98m }\end{array}$ & 0.053 \\
\hline$Z r-99$ & $4.00 E-02$ & $\begin{array}{l}\mathrm{Nb}-99 \\
\mathrm{Nb}-99 \mathrm{~m}\end{array}$ & $\begin{array}{l}0.7 \\
0.3\end{array}$ \\
\hline
\end{tabular}


Table A-15

Dose Conversion Factors

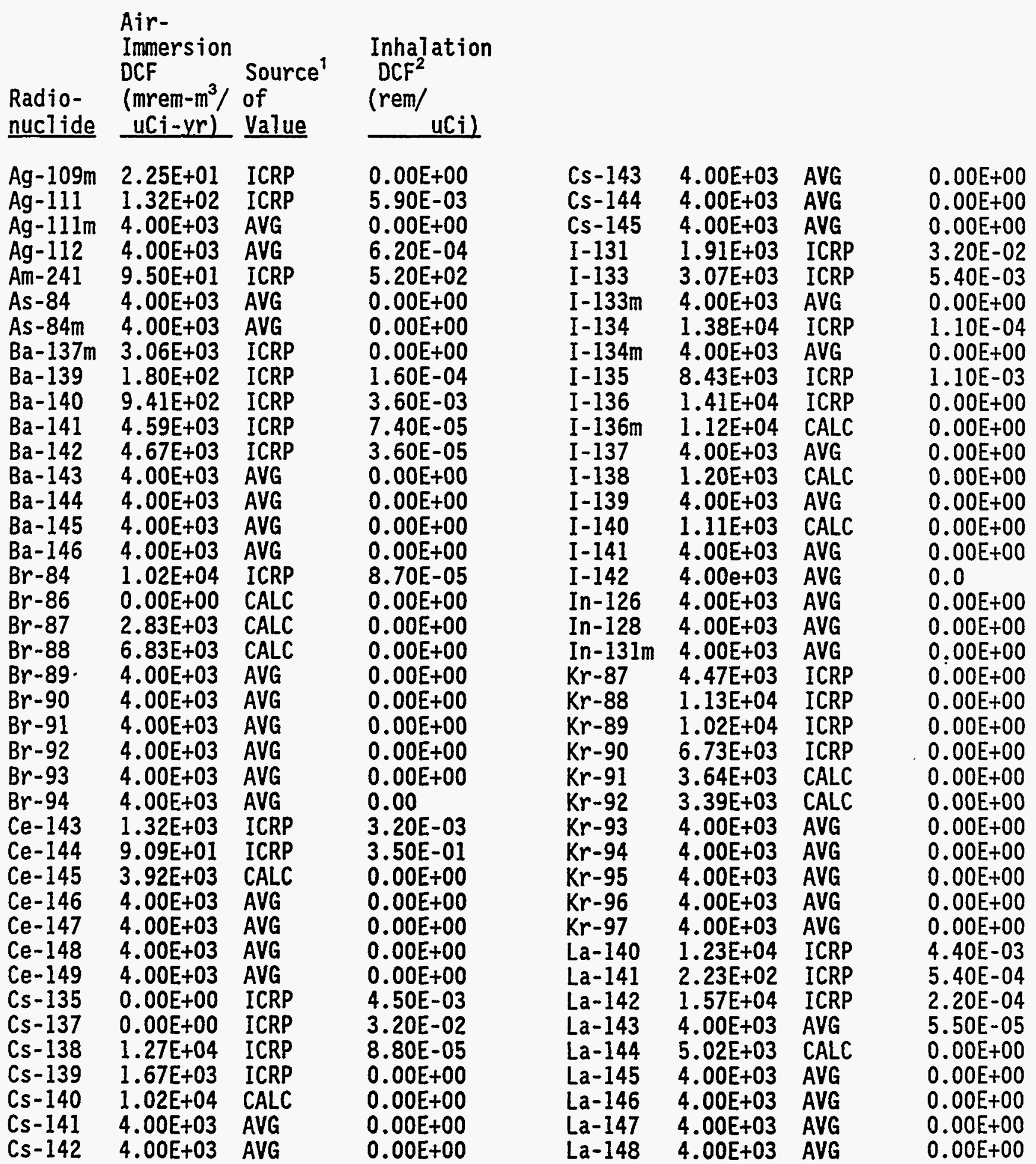




\begin{tabular}{|c|c|c|c|}
\hline 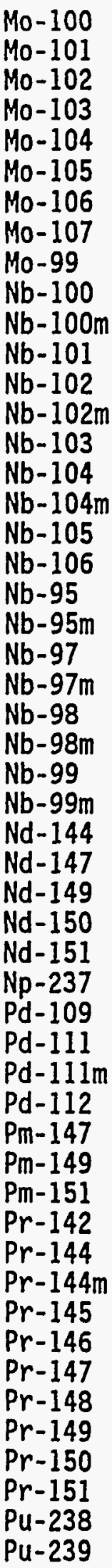 & $\begin{array}{l}4.00 E+03 \\
7.94 E+03 \\
4.00 E+03 \\
4.00 E+03 \\
4.00 E+03 \\
0.00 E+00 \\
4.00 E+03 \\
4.00 E+03 \\
7.99 E+02 \\
0.00 E+00 \\
4.00 E+03 \\
1.46 E+03 \\
4.00 E+03 \\
4.00 E+03 \\
4.00 E+03 \\
4.00 E+03 \\
4.00 E+03 \\
4.00 E+03 \\
4.00 E+03 \\
3.97 E+03 \\
3.04 E+02 \\
3.41 E+03 \\
3.78 E+03 \\
3.32 E+02 \\
1.13 E+04 \\
7.55 E+02 \\
4.00 E+03 \\
4.00 E+03 \\
6.65 E+02 \\
4.00 E+03 \\
4.00 E+03 \\
4.00 E+03 \\
1.15 E+02 \\
3.45 E+00 \\
4.00 E+03 \\
4.00 E+03 \\
4.00 E+03 \\
1.83 E-02 \\
5.86 E+01 \\
1.68 E+03 \\
3.10 E+02 \\
1.79 E+02 \\
2.67 E+01 \\
7.94 E+01 \\
5.72 E+03 \\
3.84 E+03 \\
4.00 E+03 \\
5.86 E+02 \\
4.00 E+03 \\
4.00 E+03 \\
4.41 E-03\end{array}$ & $\begin{array}{l}\text { AVG } \\
\text { ICRP } \\
\text { AVG } \\
\text { AVG } \\
\text { AVG } \\
\text { CALC } \\
\text { AVG } \\
\text { AVG } \\
\text { ICRP } \\
\text { CALC } \\
\text { AVG } \\
\text { CALC } \\
\text { AVG } \\
\text { AVG } \\
\text { AVG } \\
\text { AVG } \\
\text { AVG } \\
\text { AVG } \\
\text { AVG } \\
\text { ICRP } \\
\text { ICRP } \\
\text { ICRP } \\
\text { ICRP } \\
\text { CALC } \\
\text { CALC } \\
\text { CALC } \\
\text { AVG } \\
\text { AVG } \\
\text { ICRP } \\
\text { AVG } \\
\text { AVG } \\
\text { AVG } \\
\text { ICRP } \\
\text { ICRP } \\
\text { AVG } \\
\text { AVG } \\
\text { AVG } \\
\text { ICRP } \\
\text { ICRP } \\
\text { ICRP } \\
\text { ICRP } \\
\text { ICRP } \\
\text { ICRP } \\
\text { CALC } \\
\text { CALC } \\
\text { ICRP } \\
\text { AVG } \\
\text { CALC } \\
\text { AVG } \\
\text { AVG } \\
\text { ICRP } \\
\text { ICRP }\end{array}$ & $\begin{array}{l}0.00 E+00 \\
3.60 E-05 \\
0.00 E+00 \\
0.00 E+00 \\
0.00 E+00 \\
0.00 E+00 \\
0.00 E+00 \\
0.00 E+00 \\
3.60 E-03 \\
0.00 E+00 \\
0.00 E+00 \\
0.00 E+00 \\
0.00 E+00 \\
0.00 E+00 \\
0.00 E+00 \\
0.00 E+00 \\
0.00 E+00 \\
0.00 E+00 \\
0.00 E+00 \\
4.50 E-03 \\
2.20 E-03 \\
7.10 E-05 \\
0.00 E+00 \\
1.00 E-04 \\
0.00 E+00 \\
0.00 E+00 \\
0.00 E+00 \\
0.00 E+00 \\
6.20 E-03 \\
0.00 E+00 \\
0.00 E+00 \\
2.60 E-05 \\
4.90 E+02 \\
1.10 E-03 \\
0.00 E+00 \\
0.00 E+00 \\
0.00 E+00 \\
3.40 E-02 \\
2.80 E-03 \\
1.60 E-03 \\
2.70 E-03 \\
4.20 E-05 \\
0.00 E+00 \\
6.40 E-04 \\
0.00 E+00 \\
2.70 E-05 \\
0.00 E+00 \\
0.00 E+00 \\
0.00 E+00 \\
0.00 E+00 \\
300 \\
330\end{array}$ \\
\hline
\end{tabular}

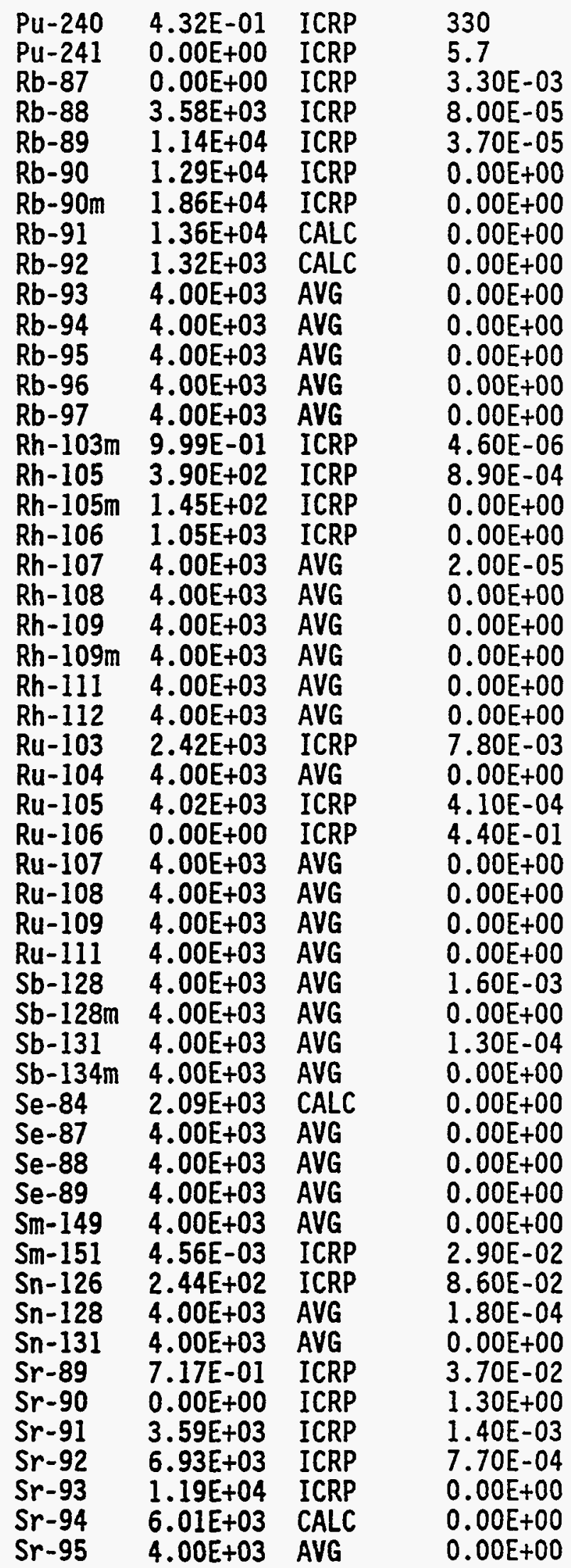




\begin{tabular}{|c|c|c|c|c|c|c|}
\hline $\begin{array}{l}S r-96 \\
S r-97 \\
S r-98 \\
S r-99 \\
T c-101 \\
T c-102 \\
T c-103 \\
T c-104 \\
T c-105 \\
T c-106 \\
T c-107 \\
T c-108 \\
T c-109 \\
T c-99 \\
T c-99 m \\
T e-131 \\
T e-131 m \\
T e-134 \\
T e-135 \\
T h-230 \\
T h-231 \\
T h-232 \\
T h-234 \\
U-233 \\
U-234 \\
U-235 \\
U-236 \\
U-238 \\
X e-133 \\
X e-133 m \\
X e-134 m \\
X e-135 \\
X e-135 m \\
X e-137 \\
X e-138 \\
X e-139 \\
X e-140 \\
X e-141 \\
X e-142 \\
X e-143 \\
X e-143 m \\
X e-144 \\
X e-145 \\
Y-100 \\
Y-101 \\
Y-91 \\
Y-91 m \\
Y-92 \\
Y-93 \\
Y-93 m \\
Y-94\end{array}$ & $\begin{array}{l}4.00 E+03 \\
4.00 E+03 \\
4.00 E+03 \\
4.00 E+03 \\
1.73 E+03 \\
4.00 E+03 \\
4.00 E+03 \\
7.29 E+03 \\
4.00 E+03 \\
4.00 E+03 \\
4.00 E+03 \\
0.00 E+00 \\
4.00 E+03 \\
2.65 E-03 \\
6.63 E+02 \\
2.16 E+03 \\
7.44 E+03 \\
4.44 E+03 \\
4.00 E+03 \\
1.96 E+00 \\
5.28 E+01 \\
9.33 E-01 \\
3.88 E+01 \\
1.20 E+00 \\
7.65 E-01 \\
7.70 E+02 \\
6.05 E-01 \\
5.19 E-01 \\
1.76 E+02 \\
1.49 E+02 \\
4.00 E+03 \\
1.25 E+03 \\
2.15 E+03 \\
9.55 E+02 \\
6.27 E+03 \\
4.00 E+03 \\
4.00 E+03 \\
4.00 E+03 \\
4.00 E+03 \\
4.00 E+03 \\
4.00 E+03 \\
4.00 E+03 \\
4.00 E+03 \\
4.00 E+03 \\
4.00 E+03 \\
1.87 E+01 \\
2.68 E+03 \\
1.32 E+03 \\
4.82 E+02 \\
4.00 E+03 \\
4.99 E+03 \\
2.59 E+03\end{array}$ & $\begin{array}{l}\text { AVG } \\
\text { AVG } \\
\text { AVG } \\
\text { AVG } \\
\text { ICRP } \\
\text { AVG } \\
\text { AVG } \\
\text { CALC } \\
\text { AVG } \\
\text { AVG } \\
\text { AVG } \\
\text { CALC } \\
\text { AVG } \\
\text { ICRP } \\
\text { ICRP } \\
\text { ICRP } \\
\text { ICRP } \\
\text { ICRP } \\
\text { AVG } \\
\text { ICRP } \\
\text { ICRP } \\
\text { ICRP } \\
\text { ICRP } \\
\text { ICRP } \\
\text { ICRP } \\
\text { ICRP } \\
\text { ICRP } \\
\text { ICRP } \\
\text { ICRP } \\
\text { ICRP } \\
\text { AVG } \\
\text { ICRP } \\
\text { ICRP } \\
\text { ICRP } \\
\text { ICRP } \\
\text { AVG } \\
\text { AVG } \\
\text { AVG } \\
\text { AVG } \\
\text { AVG } \\
\text { AVG } \\
\text { AVG } \\
\text { AVG } \\
\text { AVG } \\
\text { AVG } \\
\text { ICRP } \\
\text { ICRP } \\
\text { ICRP } \\
\text { ICRP } \\
\text { AVG } \\
\text { CALC } \\
\text { CALC }\end{array}$ & $\begin{array}{l}0.00 E+00 \\
0.00 E+00 \\
0.00 E+00 \\
0.00 E+00 \\
1.60 E-05 \\
0.00 E+00 \\
0.00 E+00 \\
6.80 E-05 \\
0.00 E+00 \\
0.00 E+00 \\
0.00 E+00 \\
0.00 E+00 \\
0.00 E+00 \\
7.50 E-03 \\
3.20 E-05 \\
9.90 E-05 \\
5.50 E-03 \\
1.00 E-04 \\
0.00 E+00 \\
3.20 E+02 \\
8.10 E-04 \\
1.60 E+03 \\
3.30 E-02 \\
1.30 E+03 \\
1.30 E+02 \\
1.20 E+02 \\
1.20 E+02 \\
1.20 E+02 \\
0.00 E+00 \\
0.00 E+00 \\
0.00 E+00 \\
0.00 E+00 \\
0.00 E+00 \\
0.00 E+00 \\
0.00 E+00 \\
0.00 E+00 \\
0.00 E+00 \\
0.00 E+00 \\
0.00 E+00 \\
0.00 E+00 \\
0.00 E+00 \\
0.00 E+00 \\
0.00 \\
0.00 E+00 \\
0.00 E+00 \\
4.40 E-02 \\
3.10 E-05 \\
6.20 E-04 \\
2.10 E-03 \\
0.00 E+00 \\
6.70 E-05 \\
3.50 E\end{array}$ & $\begin{array}{r}\text { - Source of } \\
\text { conversion factors } \\
\text { ICRP - } \\
\text { CALC - } \\
\text { AVG - } \\
2 \text { - Source, DOE } 19 \\
\text { assumed to be } 0.0 \\
\text { less than one hour }\end{array}$ & $\begin{array}{l}\text { AVG } \\
\text { AVG } \\
\text { CALC } \\
\text { AVG } \\
\text { AVG } \\
\text { AVG } \\
\text { AVG } \\
\text { AVG } \\
\text { AVG } \\
\text { AVG } \\
\text { CALC } \\
\text { AVG } \\
\text { AVG } \\
\text { ICRP } \\
\text { ICRP } \\
\text { ICRP } \\
\text { AVG } \\
\text { CALC }\end{array}$ & $\begin{array}{l}0.00 E+00 \\
0.00 E+00 \\
0.00 E+00 \\
0.00 E+00 \\
0.00 E+00 \\
0.00 E+00 \\
0.00 E+00 \\
0.0 \\
0.0 \\
0.00 E+00 \\
0.00 E+00 \\
0.00 E+00 \\
0.00 E+00 \\
3.20 E-01 \\
1.90 E-02 \\
4.00 E-03 \\
0.00 E+00 \\
0.00 E+00\end{array}$ \\
\hline
\end{tabular}


Table A-16

X\Q Values for an Inert Gas at Selected Distances ${ }^{1}$

Downwind

\begin{tabular}{|c|c|c|c|c|c|c|c|c|c|c|}
\hline $\begin{array}{c}\text { Oistance } \\
(\mathrm{m})\end{array}$ & 1.0 & 2.0 & 3.0 & $\begin{array}{r}W i \\
4.0 \\
\end{array}$ & 5.0 & $\begin{array}{r}\text { Speed }( \\
6.0 \\
\end{array}$ & 7.0 & 8.0 & 9.0 & 10.0 \\
\hline $\begin{array}{l}100 \\
200 \\
300 \\
500 \\
700 \\
1000 \\
1500 \\
2000 \\
3000 \\
5000 \\
10000\end{array}$ & $\begin{array}{l}.46 e-1 \\
.13 e-1 \\
.60 e-2 \\
.23 e-2 \\
.12 e-2 \\
.64 e-3 \\
.35 e-3 \\
.23 e-3 \\
.12 e-3 \\
.67 e-4 \\
.29 e-4\end{array}$ & $\begin{array}{l}.23 e-1 \\
.63 e-2 \\
.30 e-2 \\
.12 e-2 \\
.62 e-3 \\
.32 e-3 \\
.17 e-3 \\
.11 e-3 \\
.62 e-4 \\
.33 e-4 \\
.14 e-4\end{array}$ & $\begin{array}{l}.15 e-1 \\
.42 e-2 \\
.20 e-2 \\
.77 e-3 \\
.41 e-3 \\
.21 e-3 \\
.12 e-3 \\
.76 e-4 \\
.41 e-4 \\
.22 e-4 \\
.95 e-5\end{array}$ & $\begin{array}{l}.11 e-1 \\
.32 e-2 \\
.15 e-2 \\
.58 e-3 \\
.31 e-3 \\
.16 e-3 \\
.87 e-4 \\
.57 e-4 \\
.31 e-4 \\
.17 e-4 \\
.71 e-5\end{array}$ & $\begin{array}{l}.91 e-2 \\
.25 e-2 \\
.12 e-2 \\
.46 e-3 \\
.25 e-3 \\
.13 e-3 \\
.69 e-4 \\
.45 e-4 \\
.25 e-4 \\
.13 e-4 \\
.57 e-5\end{array}$ & $\begin{array}{l}.76 e-2 \\
.21 e-2 \\
.99 e-3 \\
.38 e-3 \\
.21 e-3 \\
.11 e-3 \\
.58 e-4 \\
.38 e-4 \\
.21 e-4 \\
.11 e-4 \\
.48 e-5\end{array}$ & $\begin{array}{l}.65 e-2 \\
.18 e-2 \\
.85 e-3 \\
.33 e-3 \\
.18 e-3 \\
.91 e-4 \\
.50 e-4 \\
.32 e-4 \\
.18 e-4 \\
.95 e-5 \\
.41 e-5\end{array}$ & $\begin{array}{l}.57 e-2 \\
.16 e-2 \\
.74 e-3 \\
.29 e-3 \\
.15 e-3 \\
.80 e-4 \\
.43 e-4 \\
.28 e-4 \\
.16 e-4 \\
.84 e-5 \\
.36 e-5\end{array}$ & $\begin{array}{l}.51 e-2 \\
.14 e-2 \\
.66 e-3 \\
.26 e-3 \\
.14 e-3 \\
.71 e-4 \\
.39 e-4 \\
.25 e-4 \\
.14 e-4 \\
.74 e-5 \\
.32 e-5\end{array}$ & $\begin{array}{l}.46 e-2 \\
.13 e-2 \\
.60 e-3 \\
.23 e-3 \\
.12 e-3 \\
.64 e-4 \\
.35 e-4 \\
.23 e-4 \\
.12 e-4 \\
.67 e-5 \\
.29 e-5\end{array}$ \\
\hline
\end{tabular}

1 - X/Q values are calculated from the AIRDOSO-EPA code (Moore et al, 1977) using a dry deposition velocity of $0.0 \mathrm{~m} / \mathrm{s}$.

Table A-17

X\Q Values for Particulates at Selected Distances ${ }^{1}$

\begin{tabular}{|c|c|c|c|c|c|c|c|c|c|c|}
\hline $\begin{array}{l}\text { Downwind } \\
\text { Distance } \\
\text { (m) }\end{array}$ & 1.0 & 2.0 & 3.0 & $4.0^{\text {Wind }}$ & 5.0 & $\begin{array}{c}\text { Speed }(\mathrm{m} / \mathrm{s}) \\
6.0 \\
\end{array}$ & 7.0 & 8.0 & 9.0 & 10.0 \\
\hline $\begin{array}{l}100 \\
200 \\
300 \\
500 \\
700 \\
1000 \\
1500 \\
2000 \\
3000 \\
5000 \\
10000\end{array}$ & $\begin{array}{l}.43 e-1 \\
.11 e-1 \\
.51 e-2 \\
.19 e-2 \\
.97 e-3 \\
.48 e-3 \\
.25 e-3 \\
.16 e-3 \\
.82 e-4 \\
.40 e-4 \\
.14 e-4\end{array}$ & $\begin{array}{l}.22 e-1 \\
.60 e-2 \\
.28 e-2 \\
.10 e-2 \\
.55 e-3 \\
.28 e-3 \\
.15 e-3 \\
.94 e-4 \\
.50 e-4 \\
.26 e-4 \\
.99 e-5\end{array}$ & $\begin{array}{l}.15 e-1 \\
.41 e-2 \\
.19 e-2 \\
.72 e-3 \\
.38 e-3 \\
.19 e-3 \\
.10 e-3 \\
.67 e-4 \\
.36 e-4 \\
.19 e-4 \\
.75 e-5\end{array}$ & $\begin{array}{l}.11 e-1 \\
.31 e-2 \\
.14 e-2 \\
.55 e-3 \\
.29 e-3 \\
.15 e-3 \\
.80 e-4 \\
.52 e-4 \\
.28 e-4 \\
.15 e-4 \\
.60 e-5\end{array}$ & $\begin{array}{l}.90 e-2 \\
.25 e-2 \\
.12 e-2 \\
.44 e-3 \\
.24 e-3 \\
.12 e-3 \\
.65 e-4 \\
.42 e-4 \\
.23 e-4 \\
.12 e-4 \\
.49 e-5\end{array}$ & $\begin{array}{l}.75 e-2 \\
.21 e-2 \\
.97 e-3 \\
.37 e-3 \\
.20 e-3 \\
.10 e-3 \\
.55 e-4 \\
.36 e-4 \\
.19 e-4 \\
.10 e-4 \\
.42 e-5\end{array}$ & $\begin{array}{l}.65 e-2 \\
.18 e-2 \\
.83 e-3 \\
.32 e-3 \\
.17 e-3 \\
.88 e-4 \\
.47 e-4 \\
.31 e-4 \\
.17 e-4 \\
.89 e-5 \\
.37 e-5\end{array}$ & $\begin{array}{l}.57 e-2 \\
.16 e-2 \\
.73 e-3 \\
.28 e-3 \\
.15 e-3 \\
.77 e-4 \\
.42 e-4 \\
.27 e-4 \\
.15 e-4 \\
.78 e-5 \\
.33 e-5\end{array}$ & $\begin{array}{l}.50 e-2 \\
.14 e-2 \\
.65 e-3 \\
.25 e-3 \\
.13 e-3 \\
.69 e-4 \\
.37 e-4 \\
.24 e-4 \\
.13 e-4 \\
.70 e-5 \\
.29 e-5\end{array}$ & $\begin{array}{l}.45 e-2 \\
.13 e-2 \\
.59 e-3 \\
.23 e-3 \\
.12 e-3 \\
.62 e-4 \\
.34 e-4 \\
.22 e-4 \\
.12 e-4 \\
.63 e-5 \\
.27 e-5\end{array}$ \\
\hline
\end{tabular}

1 - X/Q values are calculated from the AIRDOSO-EPA code (Moore et al, 1977) using a dry deposition velocity of $0.0018 \mathrm{~m} / \mathrm{s}$. 
APPENDIX B

HAND CALCULATION

FOR THE SELENIUM-89 NUCLIDE 
Appendix B - Hand Calculation

Los Alamos Technical Associates. Inc. ENGINEERING CALCULATIONS

\begin{tabular}{|l|l|l|l}
\hline JOB & DATE & $\begin{array}{c}\text { SHEET NO } \\
1\end{array}$ \\
\hline DESCRIPTION & TALC. BY & APPROVED BY \\
& &
\end{tabular}

Consider the XGODVA accident scenario and the decay shame:

$$
\mathrm{Se}-89 \longrightarrow \mathrm{Br}-89 \rightarrow \mathrm{Kr}-89 \rightarrow \mathrm{Kr}-88 \mathrm{Rb}-89
$$

for which we have the following initial value a

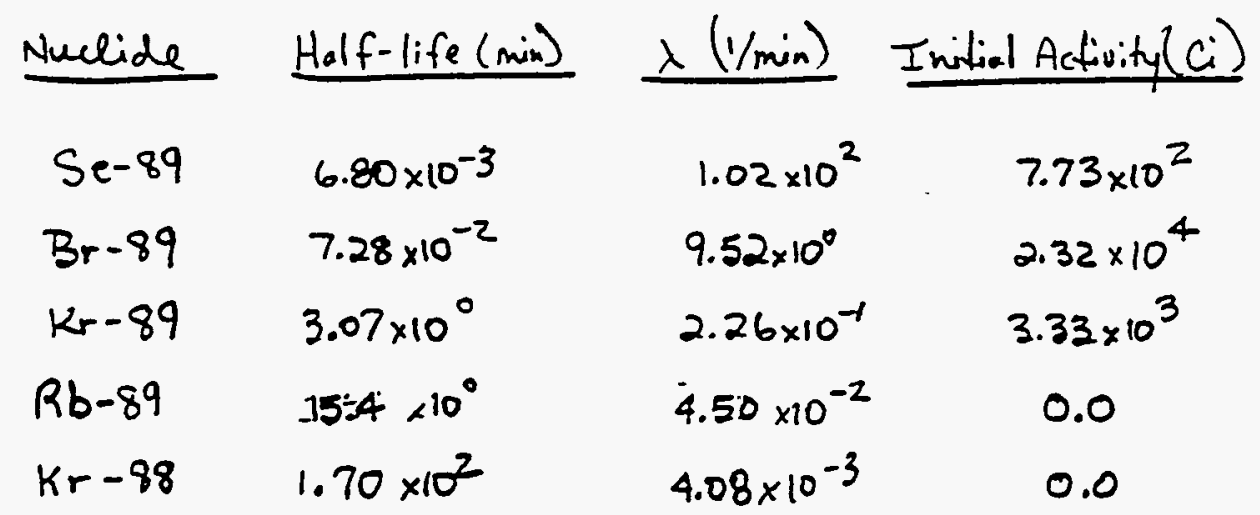

Using the Batsman equations, we calculate the amount of activity for parent (Se-89), daughter (Br-89), gran laughter (kr-89), and. great granddaughter $(R B-89)$. It is noted that the Br-99 bimodal dean goes $93.8 \%$ to $\mathrm{Kr}-89$ and 6.270 to $\mathrm{Kr}-88$. The results are to be compared with: the CRIT8-risuts for the first time packet which have a building fraction release of 0.70 and a decay time of 3.583 minutes to the closest receptor at $200 \mathrm{~m}$.

69 
Appendix B - Hand Calculation (continued)

Los Alamo Technical Associates, Inc. ENGINEERING CALCULATIONS

\begin{tabular}{|l|l|l|l}
\hline JOB & DATE & $\begin{array}{c}\text { SHEET NO } \\
2\end{array}$ \\
\hline DESCRIPTION & TALC. BY & APPROVED BY \\
& & \\
\hline
\end{tabular}

Residual Parent

The Baseman equation for the number of atoms of the residual parent is

(1) $\quad N_{i}=N_{1}^{0} e^{-\lambda t}$

where

$N_{1}=N_{6}$. atoms of residual parent (Se-89)

$N_{2}=$ Initial number of parent (Se-89)

$\lambda_{1}=$ Parent decay constant (1 /min)

$t=$ decay time $(3.583$ minutes $)$

The equation defining activity is

(2) $\quad A=\lambda \cdot N$

where,

$$
A .=\text { Activity (Ci). }
$$

Combining equations (1) and (2) gives

$$
\begin{aligned}
A_{1} & =\lambda_{1} N_{1}^{0} e^{-\lambda_{1} t} \\
& =A_{0} e^{-\lambda_{1} t}
\end{aligned}
$$

where

$A_{0}=$ Initial Parent Activity (C).

$A_{1}=$ Residual Parent Activity (Ci).

70 
Appendix B - Hand Calculation (continued)

Los Alamos Technical Associates, Inc. ENGINEERING CALCULATIONS

\begin{tabular}{|l|l|l|l}
\hline JOB & DATE & SHEET NO \\
\hline DESCRIPTION & TALC. BY & APPROVED BY \\
Hence & & \\
\hline
\end{tabular}

Hence,

$$
\begin{aligned}
A_{1} & =7.73 \times 10^{2} c i e^{-(102.0)(3.583)} \\
& =0.0 \mathrm{ci}
\end{aligned}
$$

$(0.70)$

Thin result agrees with the CRIT result

- Daughter Activity

- The daughter activity of Br-89 is composed of (1) a daughter product from the decay of the Se-89 parol and (2) residual initio Be -89.

(1) The number of atoms of daughter product

(3) $)=N_{2}=\frac{\lambda_{1} \lambda_{1}}{\lambda_{2}-\lambda_{1}} e^{-\lambda_{1} t}+\left[\frac{\lambda_{1} N_{1}^{0}}{\lambda_{1}-\lambda_{2}}+N_{i}^{0}\right] e^{-\lambda_{2} t}$

where,

$D=$ number of atoms of daughter

$D_{0}=$ Initial number of atoms of daughter

$\lambda_{2}=$ decay constant for the daughter

in $\therefore$ - $-2:=$

71 
Appendix B - Hand Calculation (continued)

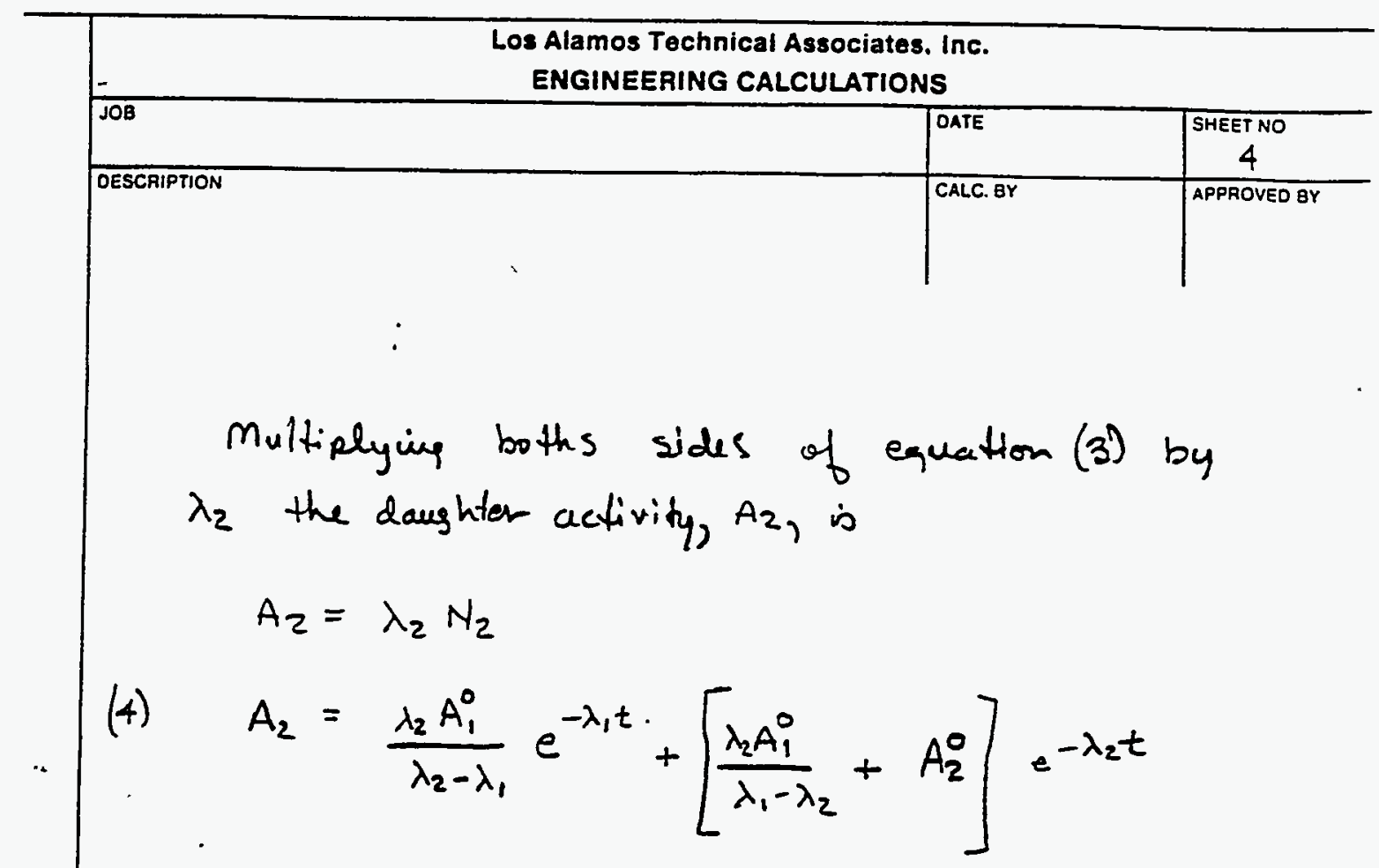

where, .

$$
A_{2}^{0}=\text { Intitial daughtor } \operatorname{activity}\left(C_{i}\right)
$$

In equation (4), we have made the substition for activities: of

$$
\begin{aligned}
& A_{1}^{0}=\lambda_{1} N_{1}^{0} \\
& A_{2}^{0}=\lambda_{2} N_{2}^{0}
\end{aligned}
$$

Hewe, the daughter activity is

$$
\begin{aligned}
& A_{2}=\frac{9.52}{9.52-102 .}(773) e^{-102 .(3.593)}+\left[\frac{9.52}{102 .-9.52} 773 .+\right. \\
& 23200 .] e^{-(9.52)(3.583)}
\end{aligned}
$$


Appendix B - Hand Calculation (continued)

Los Alamos Technical Associates. Inc. ENGINEERING CALCULATIONS

\begin{tabular}{|l|l|l|l}
\hline JOB & DATE & SHEET NO \\
\hline DESCRIPTION & TALC. BY & APPROVED BY \\
& & \\
\hline
\end{tabular}

$$
\begin{aligned}
A_{2} & =(-.103)(773)(0.0)+(79.6+23200)\left(1.54 \times 10^{-15}\right) \\
& =3.59 \times 10^{-11}
\end{aligned}
$$

Multiplying this value by the release fraction of 0.70 , the daughter activity of $\mathrm{Br}-89$ is $2.51 \times 10^{-11} \mathrm{C}$. The cert code calculates a value of $2.50 \times 10^{-11} \mathrm{C}$.

Granddaughter Activities

The Baseman equation for ground daughter $(G O)$ growth is

(5)

$$
\begin{aligned}
N_{3}= & \frac{\lambda_{1} \lambda_{2} N_{1}^{0}}{\left(\lambda_{2}-\lambda_{1}\right)\left(\lambda_{3}-\lambda_{1}\right)} e^{-\lambda_{1} t}+\left[\frac{\lambda_{1} \lambda_{2} N_{1}^{0}}{\left(\lambda_{1}-\lambda_{2}\right)\left(\lambda_{3}-\lambda_{2}\right)}+\frac{\lambda_{2} N_{2}^{0}}{\lambda_{3}-\lambda_{2}}\right] \\
& e^{-\lambda_{2} t}+\left[\frac{\lambda_{1} \lambda_{2} N_{1}^{0}}{\left(\lambda_{1}-\lambda_{3}\right)\left(\lambda_{2}-\lambda_{3}\right)}+\frac{\lambda_{2} N_{2}^{0}}{\lambda_{2}-\lambda_{3}}+N_{3}^{0}\right] e^{-\lambda_{3} t}
\end{aligned}
$$

where,

$N_{3}=$ number of atoms of the GO.

$N_{3}^{0}=$ Initial number of atoms of GD

$\lambda_{3}=$ GD decay constant

multiplying each side of equation (5) by $\lambda_{3}$ gives

73 
Appendix B - Hand Calculation (continued)

Los Alamos Technical Associates. Inc. ENGINEERING CALCULATIONS

\begin{tabular}{|l|l|l|l}
\hline JOB & DATE & $\begin{array}{c}\text { SHEET NO } \\
6\end{array}$ \\
\hline DESCRIPTION & TALC. BY & APPROVED BY \\
& &
\end{tabular}

(6) $\quad A_{3}=\lambda_{3} N_{3}=\frac{\lambda_{2} \lambda_{3} A_{1}^{0}}{\left(\lambda_{2}-\lambda_{1}\right)\left(\lambda_{3}-\lambda_{1}\right)} e^{-\lambda_{1} t}+\left[\frac{A_{1}^{0} \lambda_{2} \lambda_{3}}{\left(\lambda_{1}-\lambda_{2}\right)\left(\lambda_{3}-\lambda_{2}\right)}+\frac{\lambda_{3} A_{2}^{0}}{\lambda_{3}-\lambda_{2}}\right]$

$$
e^{-\lambda_{2} t}+\left[\frac{\lambda_{2} \lambda_{3} A_{1}^{0}}{\left(\lambda_{1}-\lambda_{3}\right)\left(\lambda_{2}-\lambda_{3}\right)}+\frac{\lambda_{3} A_{2}^{0}}{\lambda_{2}-\lambda_{3}}+A_{3}^{0}\right] e^{-\lambda_{3} t}
$$

The GO activity for $\mathrm{kr}-89$ is

$$
\begin{aligned}
\left(A_{3}\right)_{k r-89}= & 0.0+\left[\frac{[(773)(9.52)(.226)}{(102-9.52)(.226-9.52)}+\frac{(.226)(23200)}{(.226-9.52)}\right] \\
. & e^{-(9.52)(3.553)}+\left[\frac{(9.52)(.226)(773)}{(102 .-.226)(9.52-.226)}+\frac{(.226)(23200)}{(9.52-.226)}+\right.
\end{aligned}
$$

$$
\begin{aligned}
3330] \cdot & e^{-(220)(3.583)} \\
= & {\left[\frac{1660}{(92.5)(-9.29)}+\frac{2020}{(-9.29)}\right]\left(1.54 \times 10^{-15}\right)+} \\
& {\left[\frac{1660}{(102 .)(9.59)}+\frac{5.49}{9.29}+3330\right](.445) } \\
= & (-1.93-564)\left(1.54 \times 10^{-15}\right)+(1.75+564+3330)(.445)
\end{aligned}
$$

74 
Appendix B - Hand Calculation (continued)

Los Alamos Technical Associates, Inc. ENGINEERING CALCULATIONS

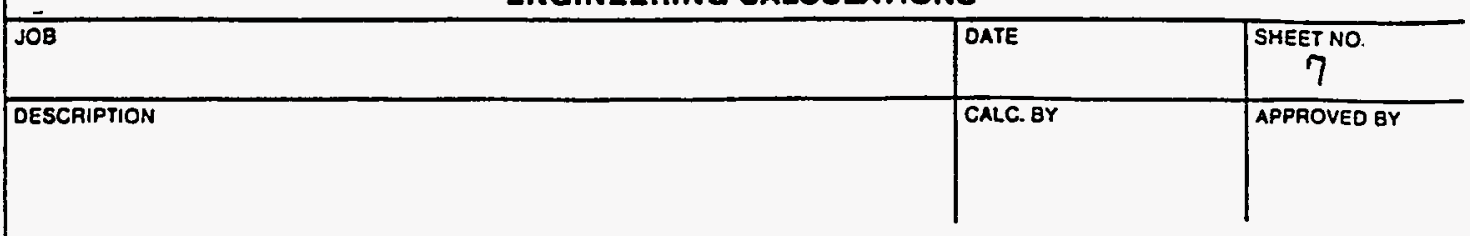

$$
=1730 \mathrm{ci}
$$

Multiplying this result by the packet release fraction of 0.70 and by the bimodal release fraction of 0.938 gives

$$
A_{k_{r}-89}=1140 \mathrm{ci}
$$

The CRIT 8 wo de calculates a Kr-89 activity of 12:30 Ci. which includes $34 \mathrm{c}$ owing to the decay of $B_{r}-90$ to $K r-89$.

Great Grouddaugiter Activity (GGO)

The Batman equation for the $G G D$ activity is

(7) $N_{4}=T_{1} e^{-\lambda_{1} t}+T_{2} e^{-\lambda_{2} t}+T_{3} e^{-\lambda_{3} t}+T_{4} e^{-\lambda_{4} t}$

where,

$N_{4}=$ number of atoms of the GGD

$\lambda_{4}=G \in D$ decay constant

and,

$$
\begin{aligned}
& T_{1}=\frac{\lambda_{1} \lambda_{2} \lambda_{3}}{\left(\lambda_{2}-\lambda_{1}\right)\left(\lambda_{3}-\lambda_{1}\right)\left(\lambda_{4}-\lambda_{1}\right)} N_{1}^{0} \\
& T_{2}=\frac{\lambda_{1} \lambda_{2} \lambda_{3}}{\left(\lambda_{1}-\lambda_{2}\right)\left(\lambda_{3}-\lambda_{2}\right)\left(\lambda_{4}-\lambda_{2}\right)} N_{1}^{0}+\frac{\lambda_{2} \lambda_{3}}{\left(\lambda_{3}-\lambda_{2}\right)\left(\lambda_{4}-\lambda_{2}\right)} N_{2}^{0}
\end{aligned}
$$

75 
Appendix B - Hand Calculation (continued)

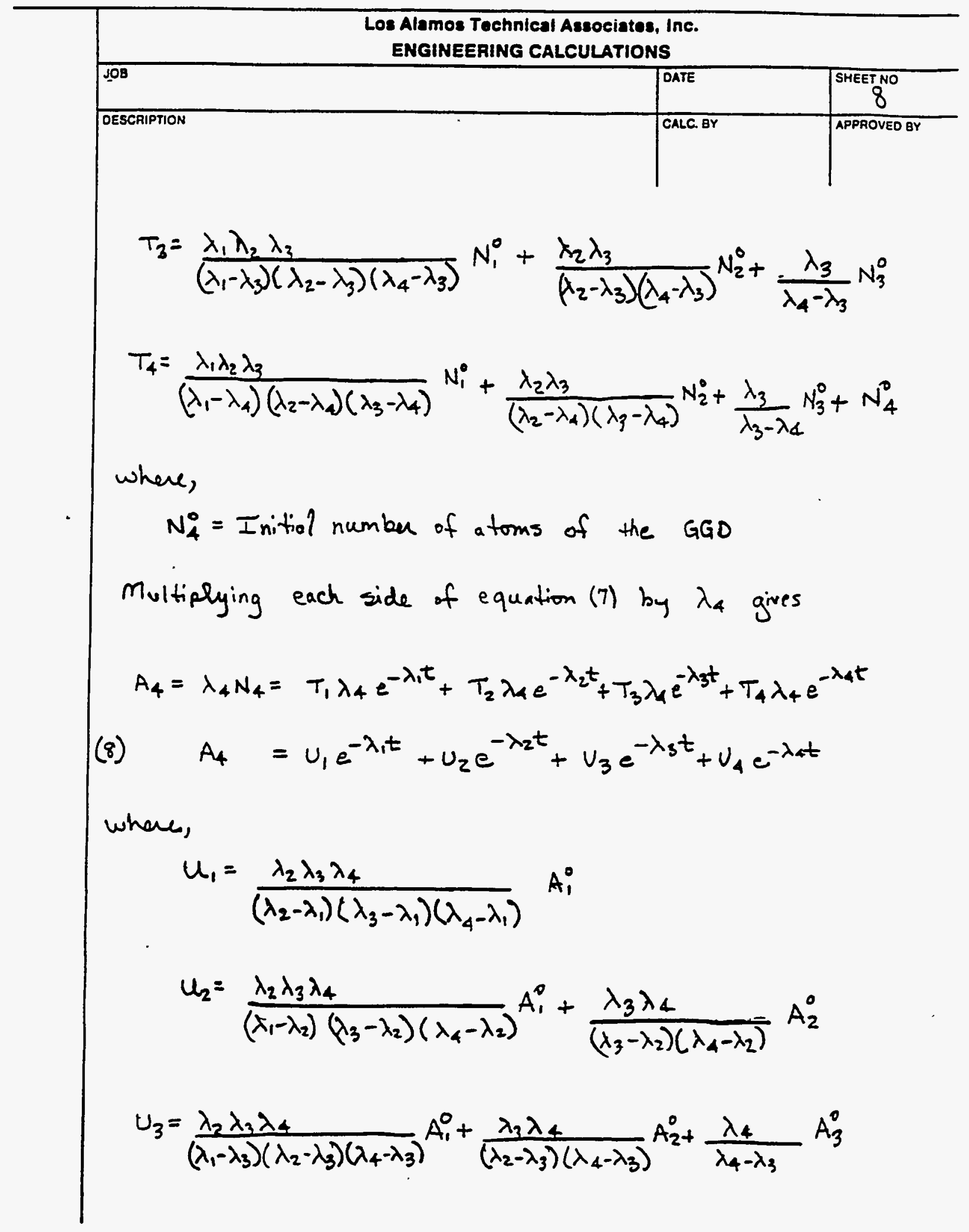


Appendix B - Hand Calculation (continued)

\begin{tabular}{|l|l|l|l}
\hline \multicolumn{3}{|c}{$\begin{array}{c}\text { LOs Alamo Technical Associates, InC. } \\
\text { ENGINEERING CALCULATIONS }\end{array}$} & \begin{tabular}{c} 
SHEET NO \\
\hline JOB
\end{tabular} \\
\hline$U_{4}=\frac{\lambda_{2} \lambda_{3} \lambda_{4}}{\left(\lambda_{4}-\lambda_{4}\right)\left(\lambda_{2}-\lambda_{4}\right)\left(\lambda_{3}-\lambda_{4}\right)} A_{1}^{0}+\frac{\lambda_{3} \lambda_{4}}{\left(\lambda_{2}-\lambda_{4}\right)\left(\lambda_{3}-\lambda_{4}\right)} A_{2}^{0}+\frac{\lambda_{4}}{\lambda_{3}-\lambda_{4}} A_{3}^{0}+A_{4}^{0}$
\end{tabular}

where,

$$
A_{4}^{\circ}=\text { Initial activity of the GGD }
$$

To calculate the GGD activity for $R b-99$, the terms $u_{2}, u_{3}$, and $U_{4}$ are calculated. $U_{1}$ need not be calculated since, as wo have seen, $e^{-\lambda t}=0$.

$$
\begin{aligned}
& u_{2}=\frac{(9.52)(.226)(.045)}{(102-9.52-)(.226-9.52)(.045-9.52)}(773)+\frac{(.226)(.045)\left(2.32 \times 10^{4}\right)}{(.226-9.52)(045-9.52)} \\
& =\frac{\left(7.68 . .1 \times 10^{-2}\right)}{(92.5)(-9.27)(-9.48)}(773)+\frac{.0102}{(-9.29)(-9.48)}\left(2.32 \times 10^{4}\right) \\
& =9.19: \times 10^{-3}+2.68 \\
& ={ }^{\prime}=2.69 \\
& U_{3}=\frac{.0958}{(102-.226)(9.52-.226)(.045-.226)}(773)+\frac{.0202)\left(2.32 \times 10^{4}\right)}{(9.52-.226)(.045-.226)} \\
& +\frac{.075}{.045-.226}(3330 .)
\end{aligned}
$$


Appendix B - Hand Calculation (continued)

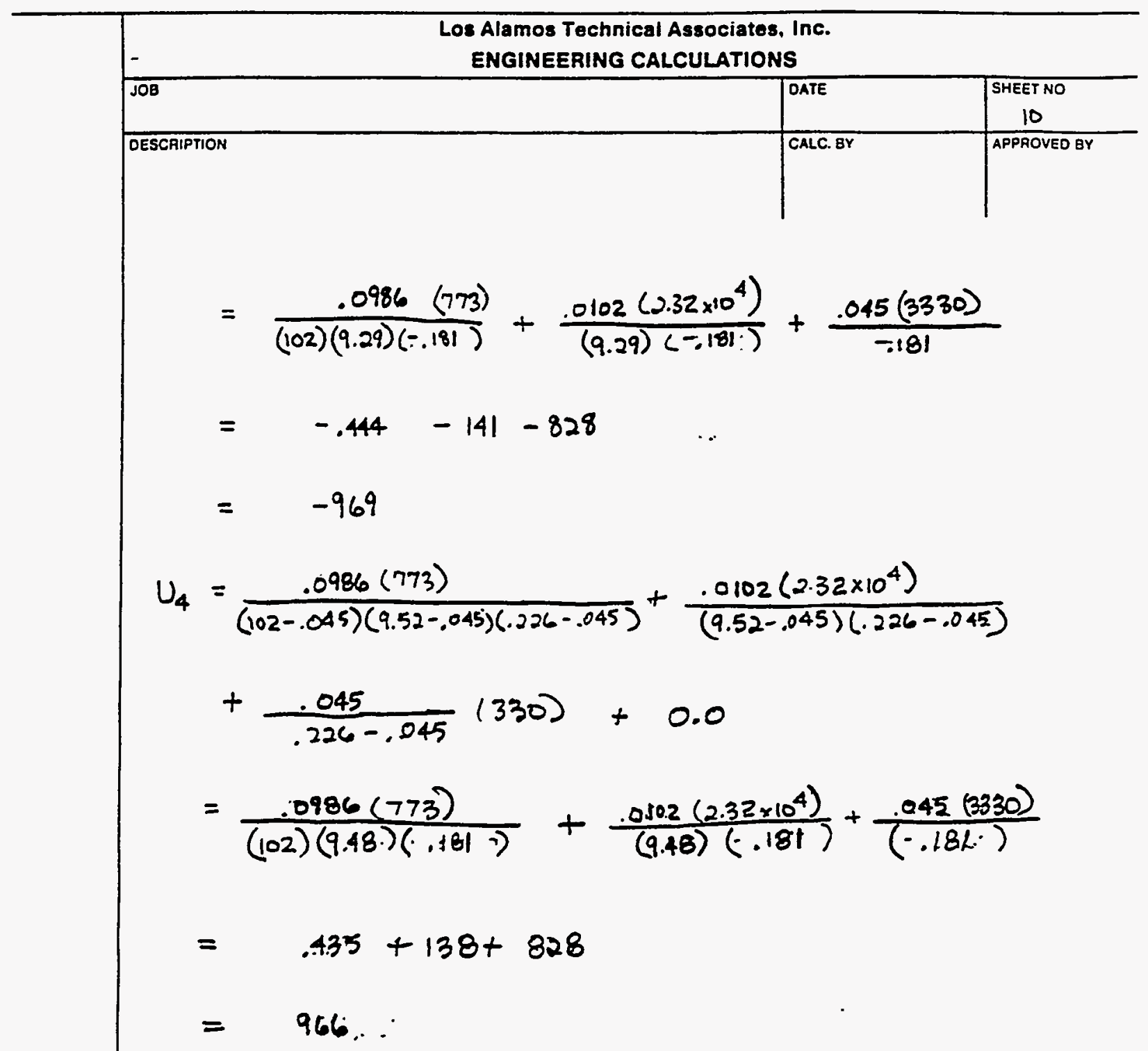

Substituting the U's in equation (B) gives

$$
\begin{aligned}
A_{4} & =2.69 e^{(-9.52)(3.513)}-.969 \cdot e^{(-.226)(3.593)}+.966 ., e^{(-.045)(3.583)} \\
& =4.13 \times 10^{-15}-431 \cdot+222 . \\
& =391 \cdot \mathrm{ci}
\end{aligned}
$$

78 
Appendix B - Hand Calculation (concluded)

Los Alamos Technical Associates, Inc. ENGINEERING CALCULATIONS

JOE

DESCRIPTION

CALC. Br

SHEET NO

Muttireying this result by the packet release fraction of 0.70 gives

$$
A_{R b-89}=274 C i
$$

The CRTs code calculates a Rb-89 activity of $277 \mathrm{ci}$.

The minor differences in results between the hand calculation and the chris code are due to the retention of only the third significant figure for the decay constants. Whereas, the computer retains six. significant figures, an error on the order of $1 \%$ may be expected.

79 
APPENDIX C

REFERENCES

Bateman, H. "Solution of a System of Differential Equations Occurring in the Theory of Radio-active Transformations", Proceedings of the Cambridge Philosophical Society, vol. $X V, 1910$.

Elder, John $C$. et al, A Guide to Radiological Accident Considerations for Siting and Design of DOE Nonreactor Nuclear Facilities, Los Alamos National Laboratory, LA-10294MS, 1986.

Friedlander, G. et al, Nuclear and Radiochemistry, John Wiley \& Sons, 1981.

Graefenstedt, M. et a1, "Experimental Beta-Decay Energies of Very Neutron-Rich Fission Products with 107<=A $\Rightarrow 109 "$, Zeitschrift fur Physik A Atomic Nuclei, vol 334, no 3, 1989.

Gusev, N.G. and Dmitriev, P.P., Quantum Radiation of Radioactive Nuclides, A Data Handbook, Pergamon Press, 1979.

International Commission on Radiation Protection, Limits for Intakes of Radionuclides by Workers, Publication ICRP 30, Pergamon Press, 1978.

Mastima, J., Plutonium Release Studies, I. Release from Ignited Metal, Pacific Northwest Laboratory, BNHL-205, 1965.

Moore, R.E. et a], AIRDOSE-EPA: A Computerized Methodology for Est imating Environmental Concentrations and Dose to Man from Airborne Releases of Radionuclides, 0ak Ridge National Laboratory, ORNL-5532, 1979.

US Department of Energy, External Dose-Rate Conversion Factors for Calculation of Dose to the Public, DOE/EH-0070, 1988.

US Department of Energy, Internal Dose Conversion Factors for Calculation of Dose to the Public, DOE/EH-0071, 1988.

US Nuclear Regulatory Commission, Radiological Assessment, NUREG/CR-3332, ORNL-5968, 1983.

US Nuclear Regulatory Commission, Regulatory Guide 1.145, Atmospheric Dispersion Models for Potential Accident Consequence Assessments at Nuclear Power Plants, 1983.

US Nuclear Regulatory Commission, Regulatory Guide 3.35, Assumptions Used For Evaluating the Potential Radiological Consequences of Accidental Nuclear Criticality in a Plutonium Processing and Fuel Fabrication Plant, 1979. 